العدد الحادي والأربعون

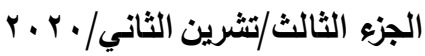

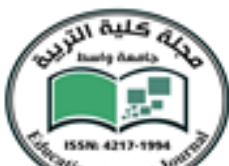

\title{
جماليات التركيب النحوي ظاهرة الحذف في شعر نزار قباني
}

أ.م د. رائدة علي أحمد عاصي

الجامعة اللبنانية/ كلية الآداب/ قسم اللغة العربية

Raida.ali.ahmad@gmail.com .Mobile number

ملخّص البحث

ترتبط اللغة بالإبداع بشكل وثثق، لأنّ اللغة هي هاجس المبدع الأول والأخير، تمنح العمل الأدبي شرط وجوده وبقائه وتميّزه وفرادته. والكاتب المبدع يعمل على إبداع لغته الخاصيّة، يهنمّ هيّة بتقجير طاقة اللغة المكنونة والمشحونة في مجال الإمكان من أجل إبداع خطاب أدبي مؤسيّ لروئية فاعلة، يجعل، ويعرف كيف يُوظّقها، ويتعامل معها نشكيلاً ونسيجاً وصناعة. فنتمو علاقاتها وبنياتها في ذاتها، وتستمدّ رموزها وأبعادها ودلالاتها من ذاتها، فتتحوّل من وسيلة تهدف إلى تأدية غاية إبلاغية تواصلية بحتة إلى الوسيلة الغاية في الوقت نفسه، يُحاورها، يكثف عن طاقاتها الجمالية الفنية، مجسّداً ذللك وفق نسيج وتشكيلات وروابط وعلاقات لغوية دلالية، تتجاوز المألوف العادي، وتكسر رتابة العلاقة بين الدال والمدلول. وهذا ما عرف بالبلاغة. والبلاغة فنّ التعبير الأدبي، وقاعدة في الوقت ذاته، فضلاً عن كونها أداة نقدية تستخدم في تقويم

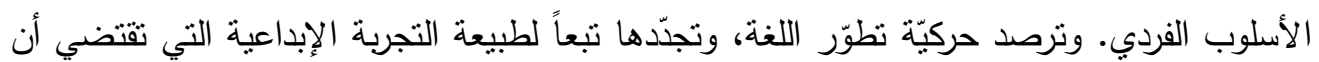
تدرس اللغة في نتوّع وظائفها، وتعدّد مستوياتها واختلاف أساليبها. وظاهرة الحذف من ظواهر اللغة العديدة، وهي ظاهرة نحوية بلاغية، اهتمّ بها النحويون القدامى والمحدثون، وأولوها اهتمامًا كبيرًا كونها تعمّق المعنى، وتُغني الدلالة، وتُبرز جماليات التركيب النحوي، والتعبير الأدبي. ونزار قباني تعامل مع اللغة على أنّها ظاهرة فنية، ولجأ إلى ظاهرة الحذف ونف ليخرج اللغة من معاجمها التقليدية، ويمنحها طاقات إيحائية، ودلالات جديدة.

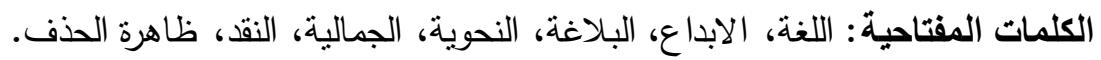




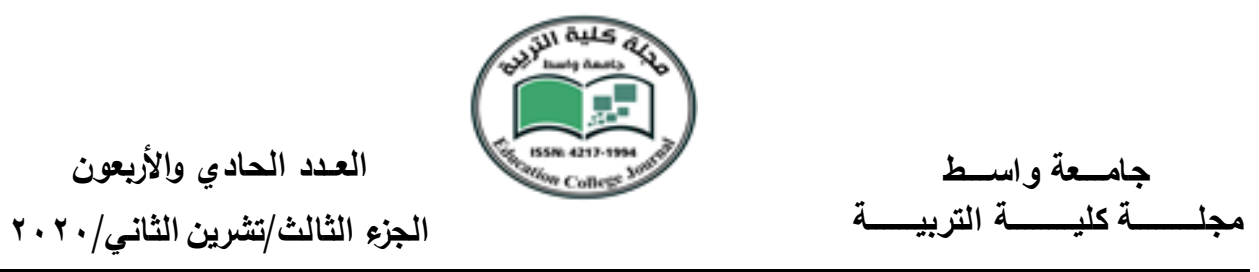

The aesthetics syntactic composition which is the phenomenon deletion in the poetry of Nizar Qabbani Professor and lecturer...

Dr. Raeda Ali Ahmad Assi. Arabic Department, Literary criticism She is a Lebanese writer and critic.

\section{Research summary}

Language is closely related to creativity, because language is the creator's first and last obsession. It gives literary work the condition of its existence, survival, distinction and uniqueness.

The creative writer wrote to deposit his own language, is interested in exploding the energy of the hidden and charged language in the field of possibility in order to create a literary discourse, that makes him establishing on effective vision and employing it in form, fabric and industry, so its relationships and structures grow in itself, and it derives its symbols, dimensions and connotations from itself, thus, it transforms from a means aiming to fulfill a purely communicative goal to the means that surpasses the ordinary and breaks the monotony of the relationship between the signifier and the signified. This is known as rhetoric.

Rhetoric is the art of literary expression and a rule at the same time, as well as being a critical tool used in evaluating in evaluating the individual style. It monitors the dynamics of language development and its regeneration according to the nature of the creative experience that requires to study the language in the diversity of its functions, the multiplicity of its levels and its different methods.

The phenomenon of deletion is one of the many phenomena of language, and it is a grammatical and rhetorical phenomenon, which the ancient and modern grammarians took care of, and gave it great attention. As it deepens the meaning, means significance and highlights the aesthetics of grammatical structure and literary expression. Nizar Qabbani treated language as an artistic phenomenon and resorted to the phenomenon of deletion to get the language out of its traditional dictionaries, he gives it suggestive energies and new connotation.

Keywords language, creativity, rhetoric, grammatical aesthetic, criticism, the phenomenon of ellipses. 
العدد الحادي والأربعون

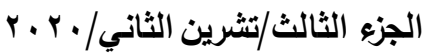

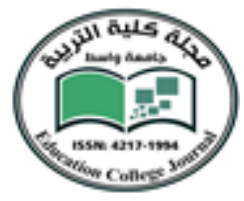

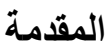

كانت البلاغة النقليدية تتولّى مهمة كثف الجمالي، ونواحي الإبداع، في العمل الأدبي لحقب

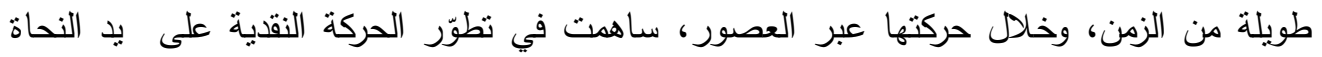

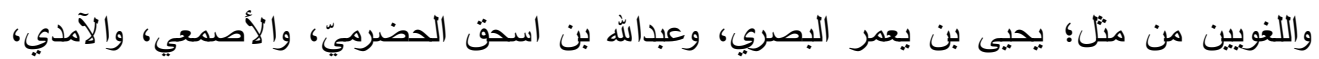

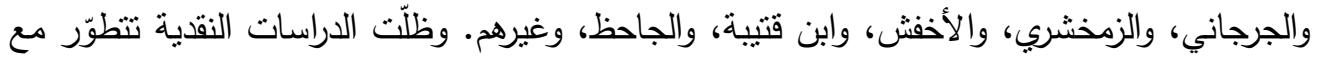
تطوّر الحياة السياسية والفكرية والنقافية، شأنها شأن كلّ العلوم الإنسانية والحضارية لتصبح أدواتها الحديثة قادرة على الإحاطة بأبعاد التجربة الفنية الكاملة في وقتتا الحاضر • والذي دفع إلى اختيار هذه القضية اللغوية الإيمان بأهمية اللغة في الحياة، فاللغة التي كانت التهادية أداة فهر

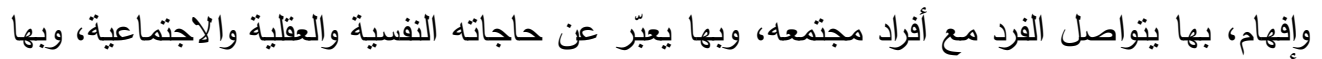
يكثف عن المعنى، ولأنّ اللغة لم تعد ترسم أبعاد وجود الإنسان فحسب، إنما تعبّر عن هواجسه وقلقه الأئم.

كما لم تعد اللغة أصوات فيزيولوجية فحسب، بل أصبحت أولويتها للفكر والدلالة (لطفي،

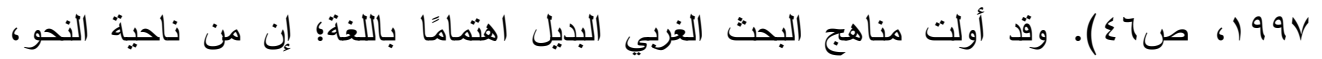

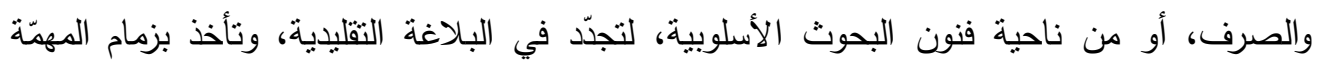
التحليلية، وهذا ما تأثرّ به الألسنيون المحثثن، ورنطوا التظم الجملة بدلالتها، لأن العلاقة بين النظم

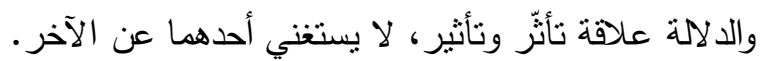

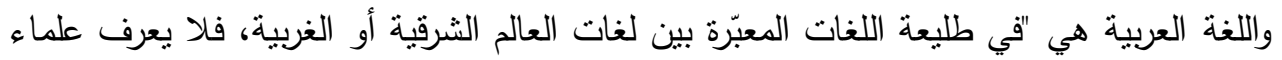
اللغات لغة قوم تتراءى لنا صفاتهم، وصفات أوطانهم من كلماتهم وألفاظهم كما تتراءى لنا أطوار

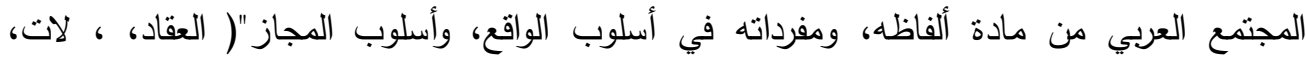
ص. ( والبلاغة العربية ظلّت لمدة طويلة تدور في فلك البلاغيين التقليديين، ما جعلت معظم بحوثهم

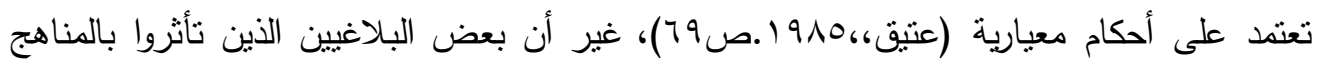
الغربية، أخذوا منها ما يتلاعم وهوية النص العربي وبيئته. وقد وجدنا في بحوثهم تنوع في طرائق

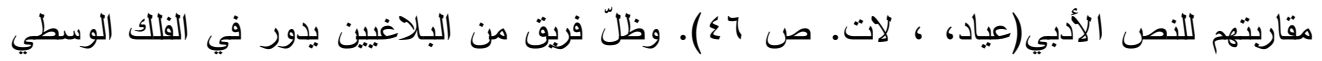

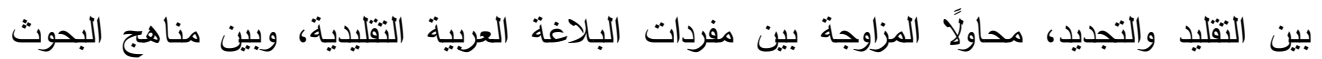

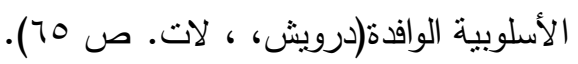


العدد الحادي والأربعون

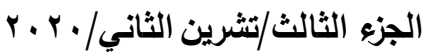

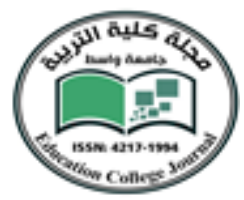

كانت قصائد نزار قباني محور الدارسين، والباحثني، تناولوها قراءة تحليلية، وأسلوبية، وجمالية،

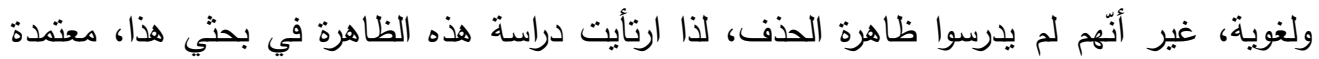

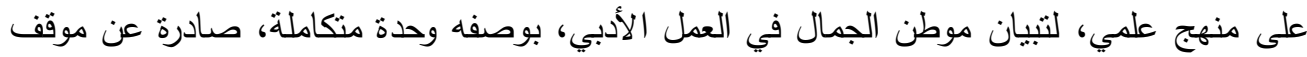
شعري واحد، بشحنته الفكرية/ الانفعالية الدالّة على الحركة اللغوية، في تركيبها ودلالتها.

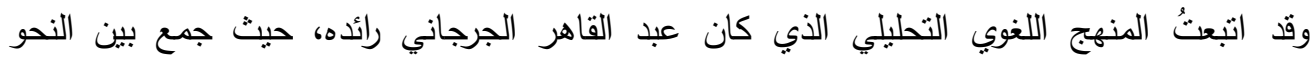

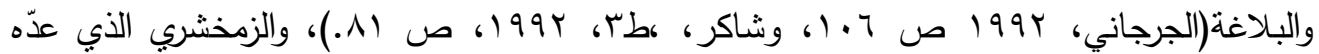

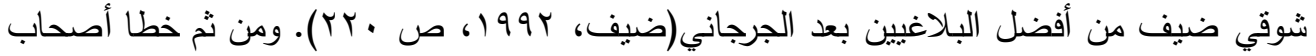
الفلسفة الجمالية خطوة منقدّمة في فهم البلاغة العربية وجمالياتها، والمحدثون نظروا إلى البلاغة نظرة

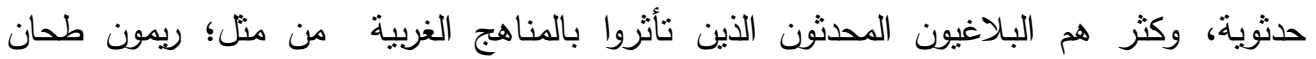

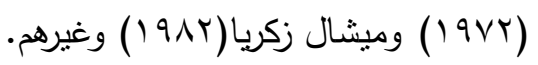
هذا ما جعلني أتتاول ظاهرة من ظواهر اللغة العديدة كالزيادة والتقديم والتأخير والاستبدال وهي ظاهرة الحذف في شعر نزار قباني، معتمدة في بحثي هذا على الأخذ من المناهج الغربية ما يتتاسب

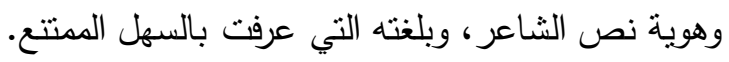

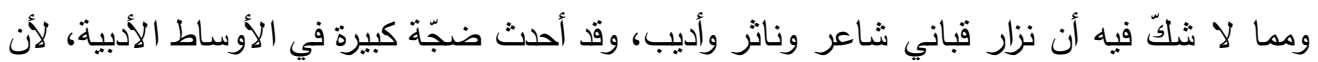

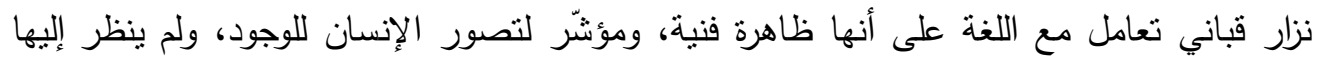

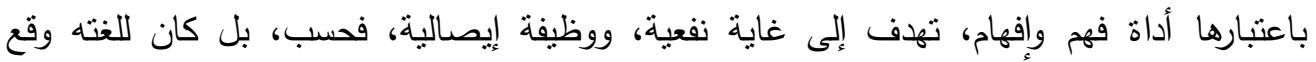
تجديديّ، خرجت عن مفهومها القديم. فالكلمة عند نزار قباني لم تعد مجرّد أصوات تزجيها قوى فيزيولوجية، أو تولّدها ظواهر عرضية،

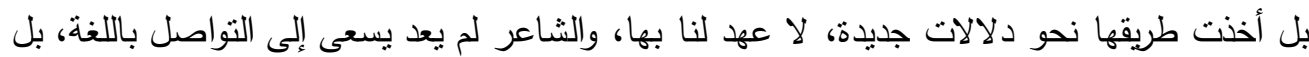
كان يسعى إلى نوصيل اللغة ذاتها، لذا نجده قد حرّر اللغة من معاجمها التقليدية، وأثنار خلفه

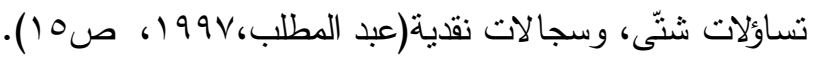
من هنا جاء هذا البحث ليطرق بابًا جديدًا في شعر نزار نثرًا، وشعرًا، وجماليات النحو، ولنفتح المزيد

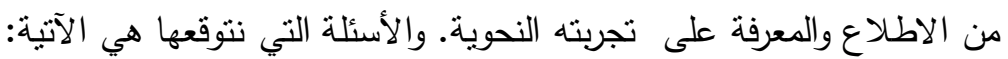
ما مدى ارتباط لغة نزار قباني بالجذور البلاغية العربية؟

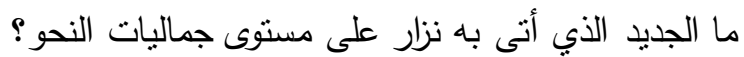

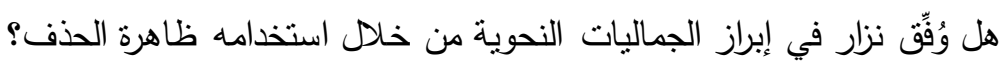


العدد الحادي والأربعون

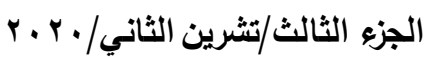

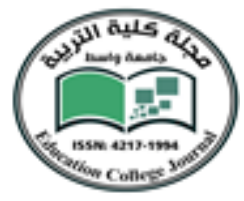

أما الهدف من هذا البحث فهو نطبيق نقنية الحذف على نماذج من شعر نزار المختارة، والكثف عن كيفية توظيفه في النص الثعري، وإكسابها قيمة فنيّة، وجمالية رفيعة. أما أهية البحث فهي في تقنية الحذف، ومحاولة الكثف عن عندية خبايا اللغة النزارية، واتصالها بجذورها النقدية البلاغية العربية. على أمل أن يكون جديدها في الدرس النطبيقي الذي يتوخّى إبراز جماليات

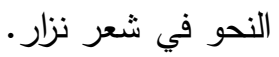
ولأنه لا بدّ لي أن أجمع بين النحوي والبلاغي في صياغة جديدة، وإيجاد منهج نقدي جديد، لأنّ النّا

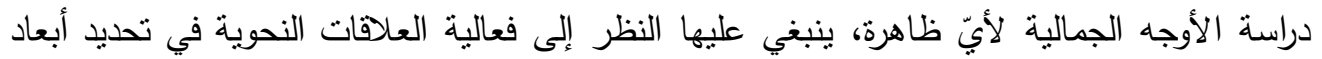
هذه الظاهرة. ولأثّنا لا ندرك العطلية الإبداعية، إلا من خلال التراكيب النحوية، فالعلاقة بين الإبداعي

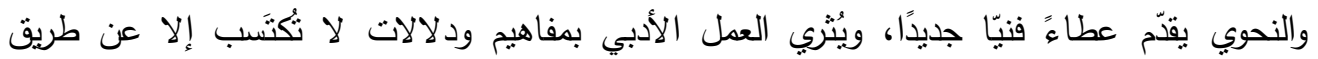

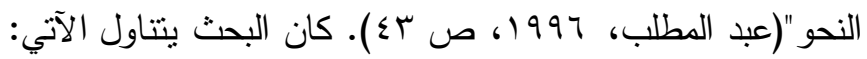
أولاً حذف المسند إليه من الجملة الاسمية. ثانيًا حذف المسند إليه من الجملة الفعلية. ثالثًا حذف الفه

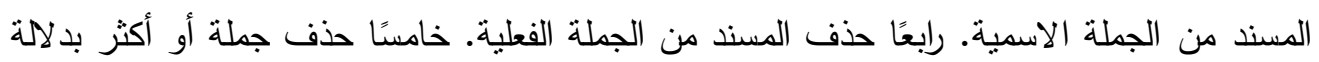
الفاء. سادسًا حذف الدفعول به. سابعًا حذف المضاف. ثامنًا حذف الهضاف إليه. تاسعًا حذف الفا الصفة. عاشرًا حذف الموصوف. حادي عشر حذف الجار والمجرور. الجملة في النحو قليمًا وحليثًا

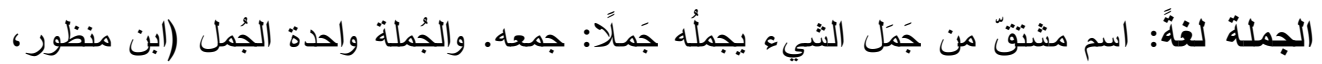
جمل) والجُملة جماعة الثيء، واعتُر فيها معنى الكثرة، فقيل لكلّ جماعة غير منفصلة "جملة" ومنه

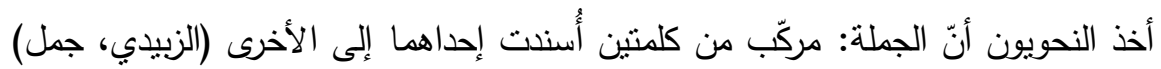

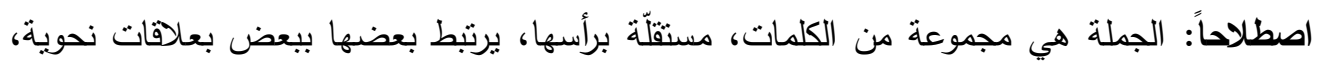

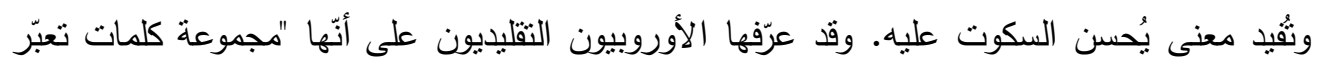

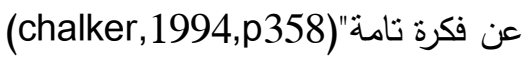
اختلف القدماء والمحدثون حول تعريف الجملة، وتصنيفها بين اسمية، وفعلية، وشرطية، وظرفية، وجهة تداخلها (الجرجاني//

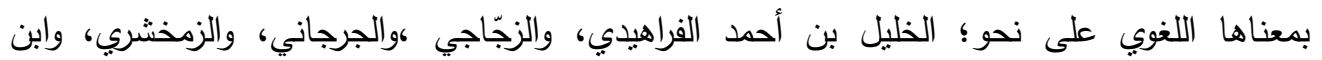

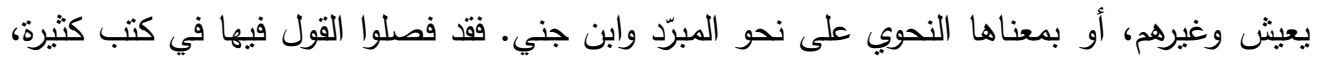

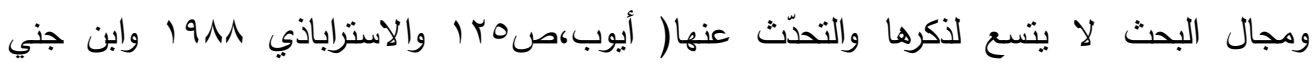
997) ص (1/1/ ). 
العدد الحادي والأربعون

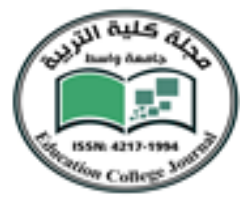

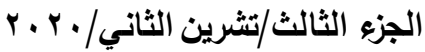

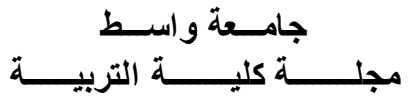

وبعد دراسة الجملة من مجموعة باحثين ثبيّن أنّ الألسنيين والمحثثين رفضوا التعريف القديم

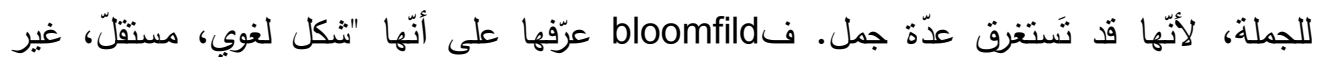
محصور بمقتضى، أي نركيب نحوي، في أي شكل لغوي أكبر منه"(bloomfild.1950.p170).

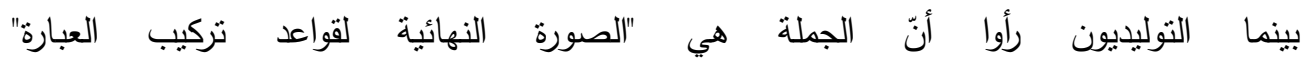
أما الوظيفيون فقد رأوا أنّها "قول تتبع فيه جميع العناصر مسندًا واحدًا، (huddleston,1986.p97)

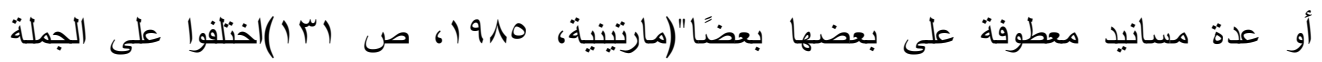

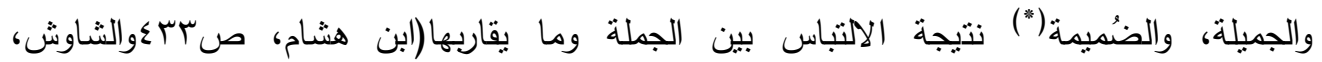

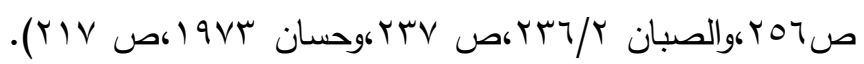
وبمجمل القول أن ألفاظ التركيب عند علماء العربية قد نكون مؤتلفة أو غير مؤتلفة، فإذا لم تفـ

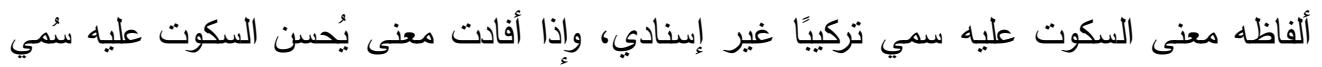
تركيب إسنادي، وسُمي جملة، والتركيب الإسنادي مُكوّن من مسند ومسند إليه إليه، والكلام عندهم عملية

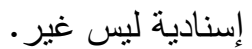
والإسناد في دراسة الجملة سنّة قديمة منّبعة عند النحاة والبلاغيين العرب، وهم متفقون على أن

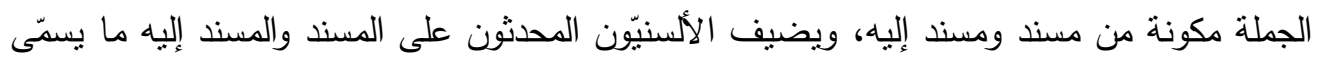
الفضلة، ويرون أن التراكيب الأساسية في اللغة العربية هي تلك التي اتفق عليها القدماء ويُضاف

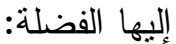
التراكيب الأسمية = مسند + مسند إليه + فضلة

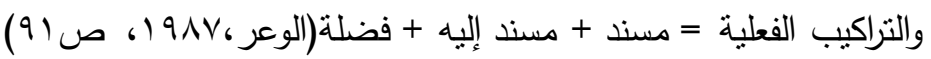

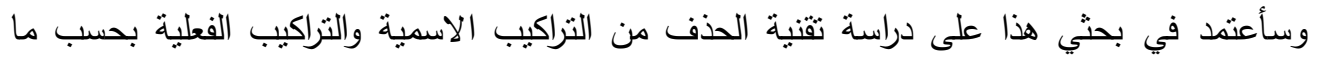
اتقق عليه القدماء والمحدثن في ديوان نزار قباني . الحذف:

لغةً: حذف الثيء بحذفه حذفًا: قطعه من طرفه، والحجام بحذف الشعر ، والحذافة: ما حذف من

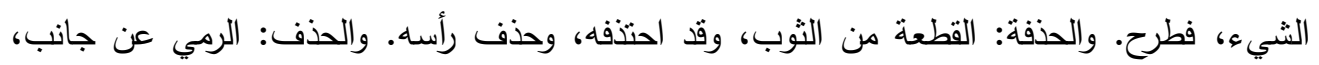

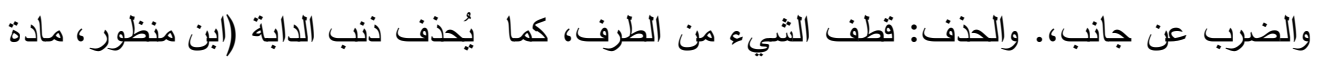
حذف). اصطلاحاً: هو ظاهرة لغوية عامّة نشترك فيها اللغات الإنسانية، حيث يميل الناطقون إلى بعض

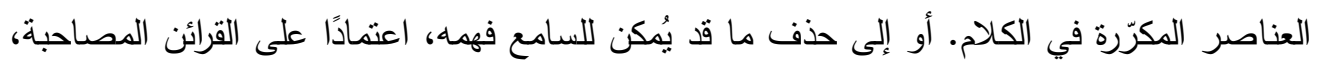


العدد الحادي والأربعون

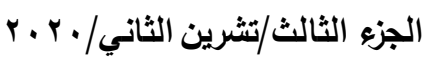

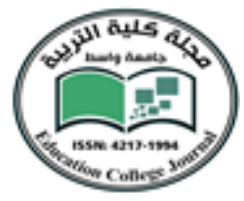

حالية كانت أو عقلية، أو لفظية، كما قد بعتري الحذف بعض عناصر الكلمة الواحدة فيسقط منها

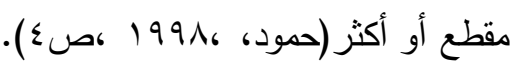

فالحذف هو إسقاط جزء من الكلام، أو كلّه، للديل على المحذوف، وإن كان لغير دليل، فهو

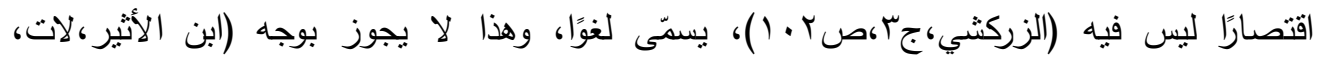

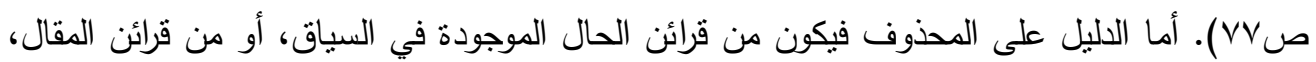

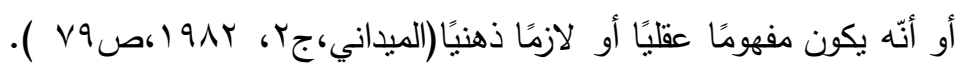

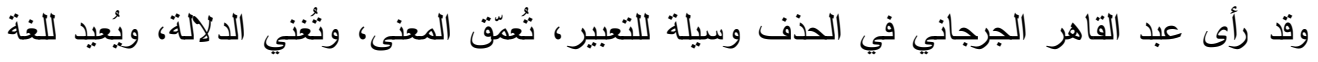

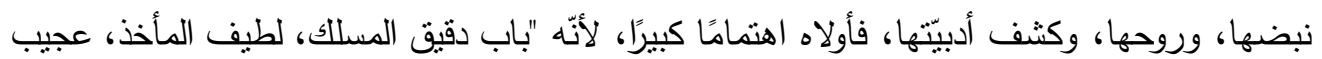

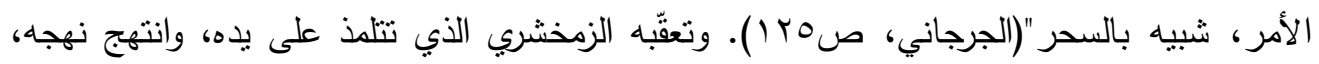

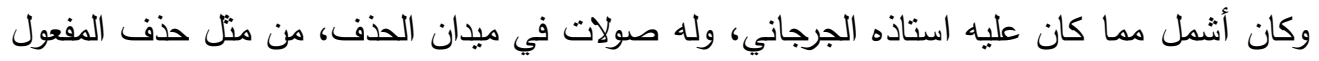

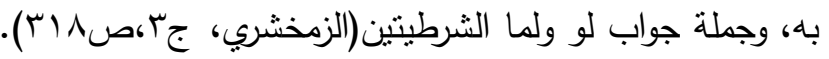

$$
\begin{aligned}
& \text { أولا - حذف المسند إليه في الجملة الإسمية }
\end{aligned}
$$

درس النحويون حالات عديدة في تقنية حذف المسند إليه، في الجملة الإسمية، وبينّا فوائد

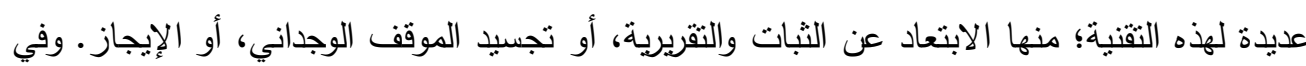
بحثا هذا، سنعرف كيف استثر الثاعر هذه التقنية في شعره، محاولين إدراك النواحي الجمالية فيه.

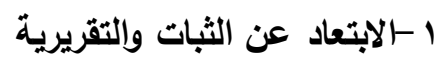

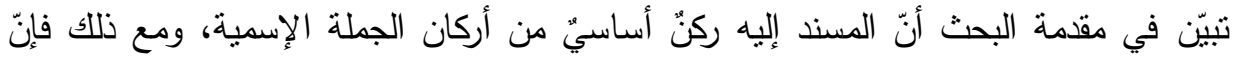

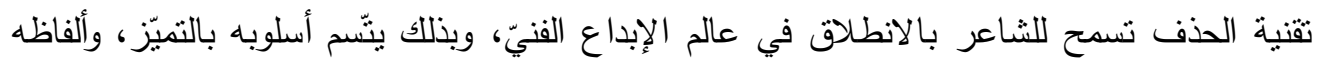

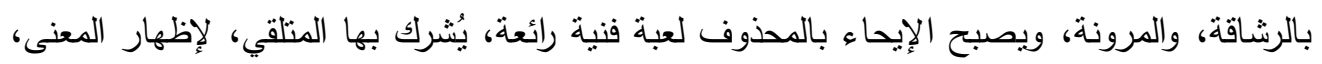

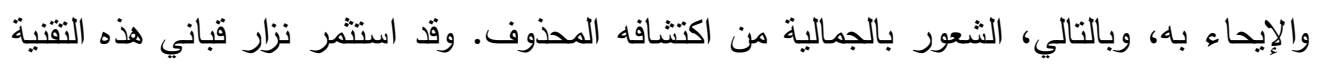

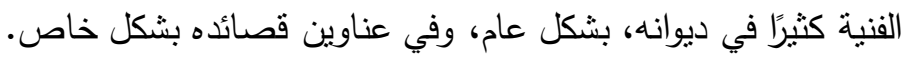

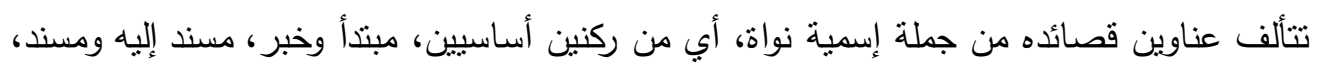

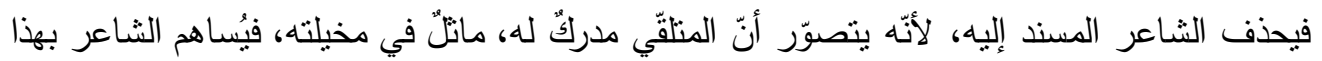

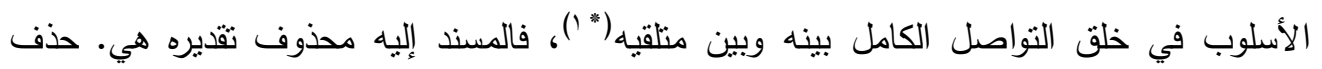

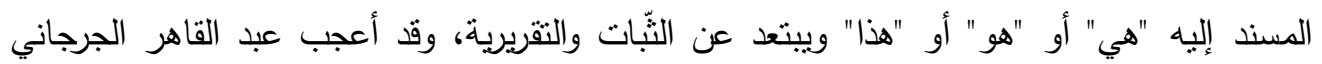

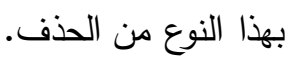

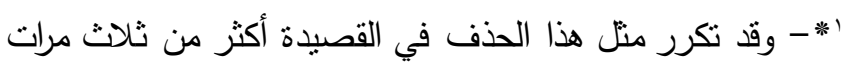


العدد الحادي والأربعون

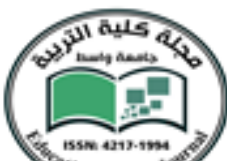

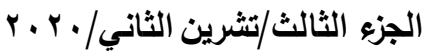

جامسـعة واســ

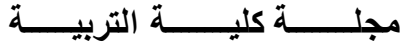

\begin{tabular}{|c|c|}
\hline التقدير & 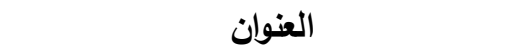 \\
\hline هي بلقيس - رسالة إلى ناصر & بلقيس - إلى ناصر 1-r - r- ع. \\
\hline هوّلاء المـهرولون & المهرولون \\
\hline 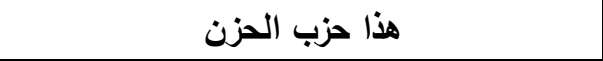 & 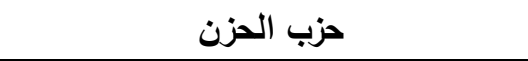 \\
\hline هذا المهرّج & المهرّج \\
\hline هذه القس - هذه وصايا إلى امرأة & القد - وصايا إلى امرأة \\
\hline هذه طريق واحد - هذه رسالة حبّ صغيرة & طريق واحد - رسدالة حبّ صغيرة \\
\hline هذه أحزان الأندلس - هذا كتاب الحبّ & أحزان الأندلس - كتاب الحبّ \\
\hline أنت أو هذا عبد المنعم - هذه غرناطة & عبد المنعم رياض - غرناطة \\
\hline هذه مورفين - هذا أحلى خبر & مورفين - أحلى خبر \\
\hline هذا عزف منفرد على الطبلة - هذه قطتي & عزف منفرد على الطبلة - قطتي الشامية \\
\hline هذه القصيدة الامشقية- هي قارئة القتجان & القصيدة الدمشقية - قارئة القتجان \\
\hline المشهُ خبر وحشيش وقمر أو (غير ذلك) & خبر وحشيش وقمر \\
\hline هذه حبلى أو (امرأة) & حبلى - - - \\
\hline رسالة إلى صديقة جليدة - رسالة إلى تلميذة & إلى صديقة جديدة - إلى تلميذة \\
\hline هي القبلة الأولى أو هذه & القبلة الأولى \\
\hline
\end{tabular}

وقد يحذف المسند إليه للغاية نفسها يقول: "كانت حبييته وزوجته. كانت مزيجًا رائعًا (ق. بلقيس) التقدير: كانت بلقيس حبييته، وكانت بلقيس زوجته. فالمسند إلبه محذوف تقديره هي. حذف المسند إليه "هي" ابتعادًا عن الثبات والثقريرية، وقد أعجب عبد القاهر الجرجاني بهذا النوع من الحذف. ومن منل ذللك يقول: أنا مسؤول عن كلّ قصيدة حبّ كتبتها/ وانتهاء من الوصول إلى جبل طارق / وانتهاء بمغادرة قصر الحمراء/ مسؤول عن سيوف بني الأحمر/ واحدًا واحدًا وعن تتهّّاتهم واحدًا واحدًا" (ق. قصبدة حبّ). والتقدير: (أنا) مسؤول عن سيوف بني الحمر. عمد الثاعر إلى حذف المسند إليه (أنا)، لأنّه معروف من سياق الكلام، ولا داعي لذكره. فالحديث المسهب عن (أناه) تأكيد على دوره، كونه إنسانًا عربيًا مسؤولاً عن ضياع المجد العربي، في اسبانيا، ولأنّ السامع عرف من السياق أن الثاعر يتحدث عن نفسه، فلا مسوغ لغوي لتكرار ضمير المتكلم المفرد العائد إلى الثاعر في السياق. 
العدد الحادي والأربعون

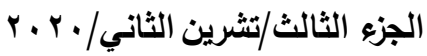

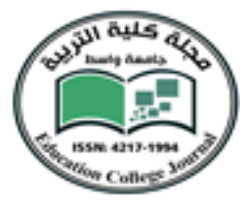

كما يقول في موضع آخر : "ما زال للشعر القديم/ نضارة/ أما الجديد/ فلا هناك جديد/ لغة بلا لغة/ وجوق ضفاد ع/ وزوابع ورقية/ ورعود" (ق. طعنوا العروبة).

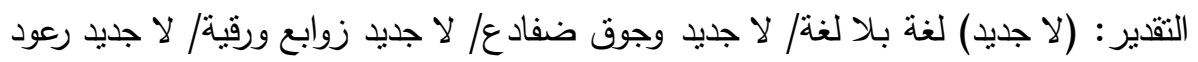

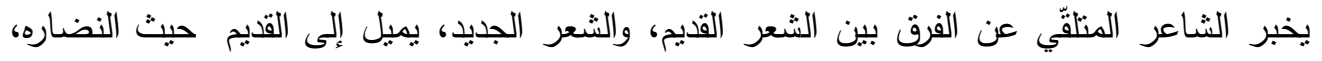

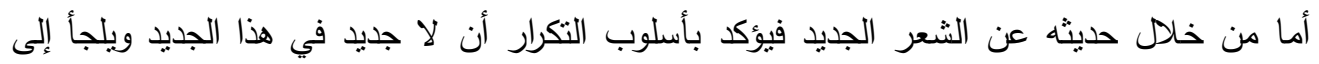

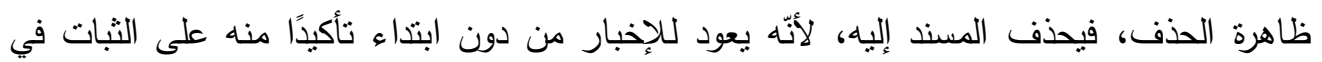

المخيّة.

\section{r r تجسيد الموقف الوجداني}

تجيش المثاعر في نفس الثاعر ، وتصل حدّ الغضب العارم في موقف انفعاليّ حادّ، فيغلي دمُه في

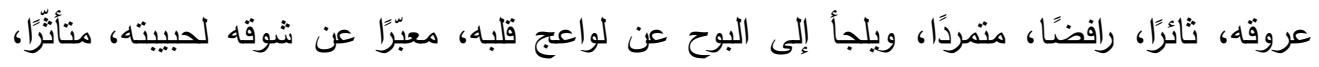

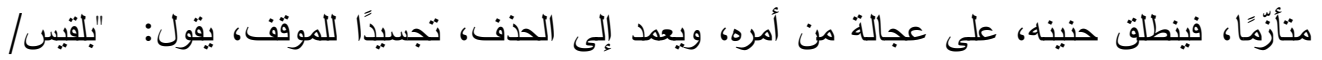

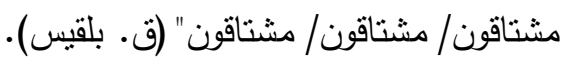
ينادي الثناعر بلقيس بحرف النداء المحذوف "يا"، ليأتي بعده المسند (الخبر)، من غير

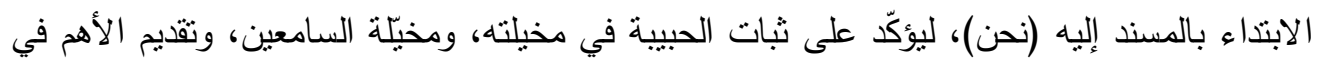

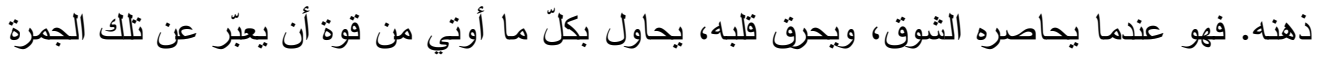
الحارقة التي تعتمل في نفسه، فيبدأ من غير تقديم، ويكرّر الخبر ثلاثل مرات متتالية لبفرغ الثحنة العاطفية التي ضاق صدره بها. وفي مقام الغضب نراه على عجلة من أمره فيبدأ بالخبر، لما له من أهية، حاذفًا المسند إليه.

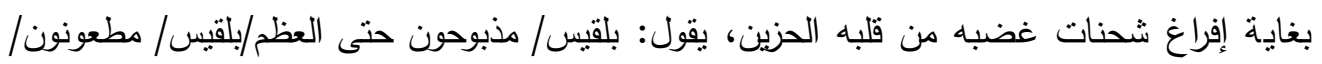
مطعونون في الأعماق (ق. بلقيس). نكاد نسمع صرخته، وثورته، ورفضه، حيث لم تحتمل سهام غضبه أن أن يبدأ ب(نحن) المسند إليه،

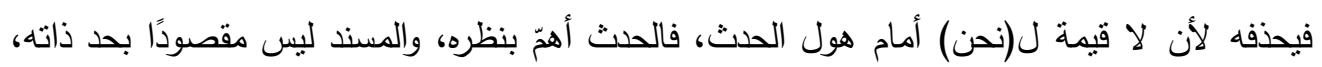
إنما المقصود هو ذلك الخبر الدال على نلك الصفات التي ذهب إليها مباشرة، وهي الإخبار عن التهن حالته الانفعالية، وعن ذلك الغضب المرجل الذي يغلي في صدره (مذبوحون - مطعونون).

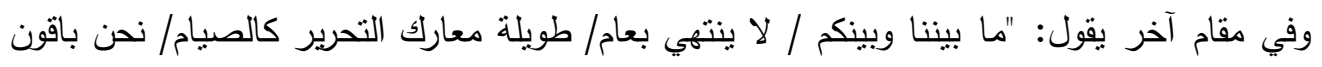

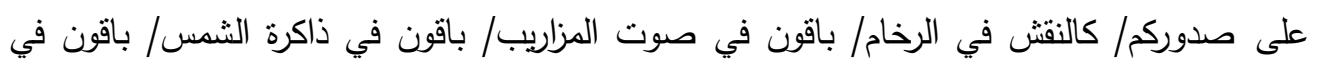

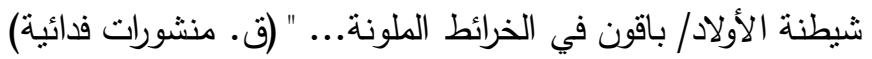


العدد الحادي والأربعون

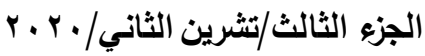

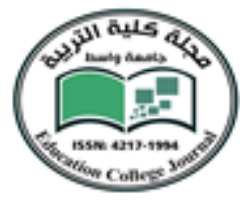

عمد الثاعر إلى حذف المسند إليه في هذا السياق تسع عشرة مرة، لتجسيد الموقف الوجداني

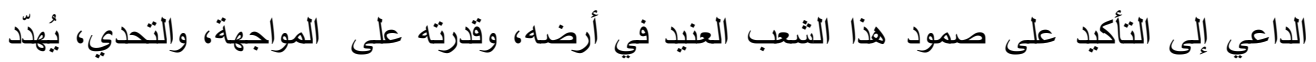
العدو بصموده، وبإصراره على الحباة المنبعثة من جذور الأرض، وما فيها، ومن عليها، إثارة إلى لى لئى

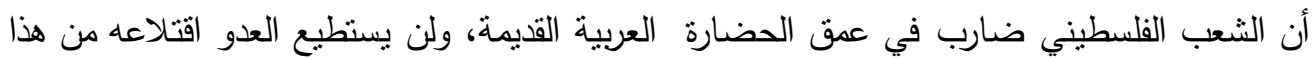
التاريخ و والجغرافيا المتجذرَين في الأرض مهما ظلم واستبّ. وفي منل هذا الموقف نسمعه يتغزّل بحبييته يقول: "عينالك كنهري أحزان/ نهري موسيقى،

لوراء وراء الأزمان/ نهري موسيقى قد ضاعا/ سيدني وأضاعاني" (ق. نهر الأحزان).

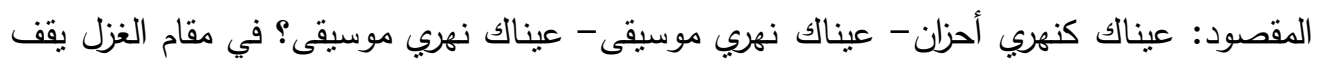

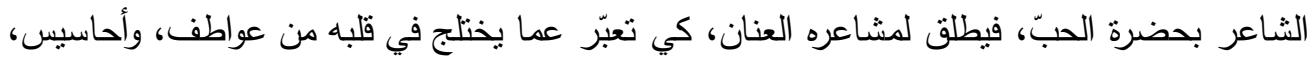
ويترك اللغة تتساب على رسلها حاذفًا ما يخفّف من شحنته العاطفية، فيسقط المسند إليه تاركًا الخبر فيران

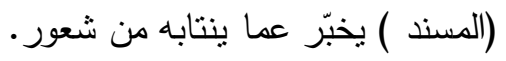

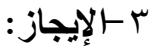
وهو وضع المعاني الكثيرة في ألفاظ أقلّ منها، وافية بالغرض المقصود، مع الإبانة والإفصاح، وينقسم إلى قسمين؛ إيجاز قصر ، وهذا لا يعنينا، وإيجاز الحذف، وهو المقصود في بحثنا

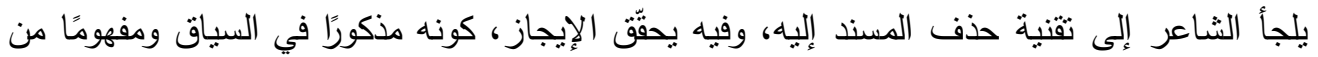
خلاله، فلا حاجة لإيراده، يقول: "السبد موجود فينا/ موجود في أرغفة الخبز ../ مرسوم فوق نجوم الإنانية

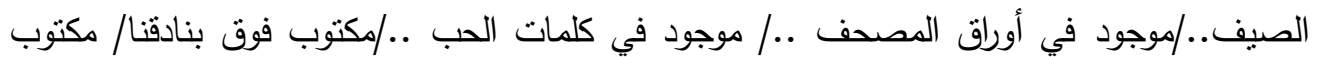

$$
\text { فوق تحدينا" (ق. إلى ناصر الهرم الرابع). }
$$

لقد حذف الثاعر المسند إليه (السيد)، لأنه معروف من سياق الكلام، مفهوم، فلا حاجة لذكره. فالثاعر يهتمّ بالصياغة الشعرية، ألفاظه تتساب رقيقة، يحذف المسند، ولحذفه فوائد جمالية على الى المستوى البلاغي، تكمن في التأكيد على وجود السيد عبد الناصر بين محبيه، وعلى إحساسه بالفخر

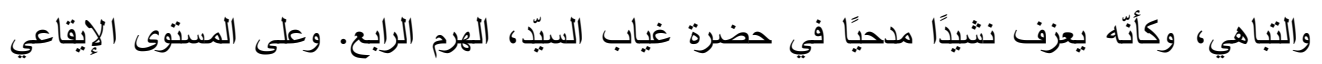
يبدو أن الثاعر يحقّق التجربة في أقصى غايتها، ويطلق اللحظة الإيقاعية التي تفجّر الاختزان، والاثتزان، ويظهر الانفعال على شكل نشيد فخري، يملأ الصدر عزة، وعنفوانًا، وكبرياء.

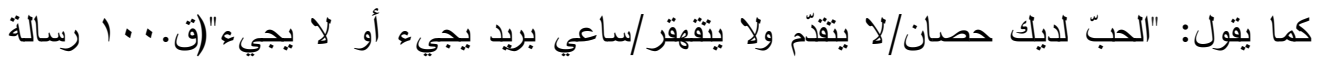


العدد الحادي والأربعون

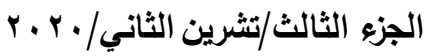

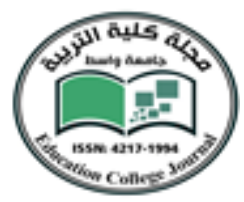

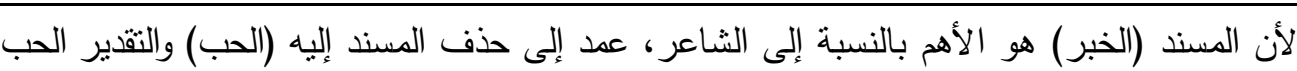

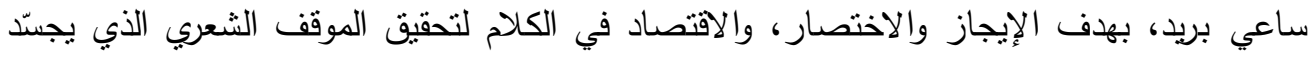

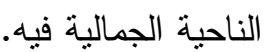

ومن منل ذلك يقول: "رسالتك في صندوق بريدي فلّة بيضاء/ حمامة أليفة../ شمس أفريقية" (ق...1. (سالة حب).

للغاية نفسها حذف الثاعر المسند إليه من حمامة بيضاء والتقدير رسالتكاء حمامة بيضاء. ذكرها في المرة الأولى، وحفاظًا على أيقاع المشاعر لديه، عمد إلى حذف المسند، وابتعد عن التكرار، لانثغاله

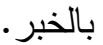

ثانياً - حذف المسند إليه من الجملة الفعلية

المسند إليه (الفاعل) عمدة في الجملة الفعلية، وركن أساسي من أركانها، وقلّما نجد من الباحثين مَن أهتّ بدراسة حذفه، ولكن هذا لا ينفي توقف بعضهم عن حالات حذف الفاعل، وإدراك أبعاده

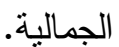
وعلى الرغم من ندرة وروده في شعر نزار، إلا أنتا سنحاول الكثف عنه، وإظهار دلالته وجماليته. وقد حقق حذف الفاعل في الديوان فوائد كثيرة منها: 1 - الإيحاء بكثرة الفاعلين

إذا ذكرنا المسند إليه في الجملة الفعلية، عرفنا من قام بالفعل، وبالتالي، حصرنا الحدث بفاعله،

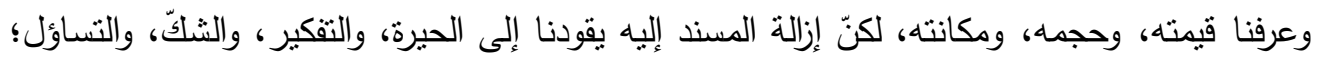
من فعل الفعل ؟ ومن قام بالفعل؟ وبهذه التساؤلات، يغيب عن خيالنا قيمة الفاعل، كما يختقي إدراكنا

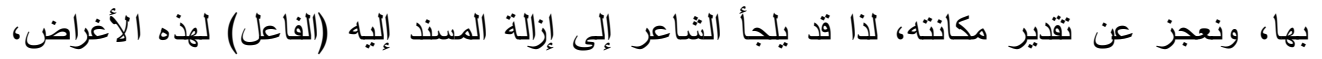

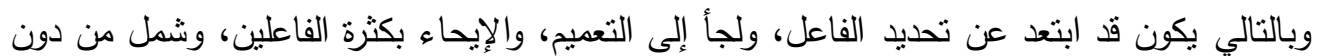

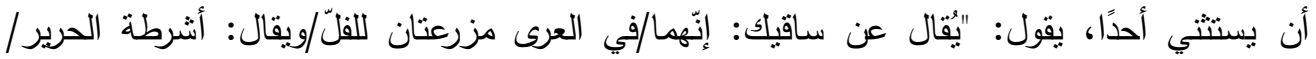

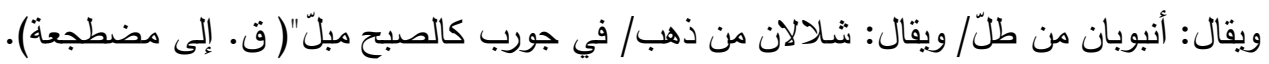

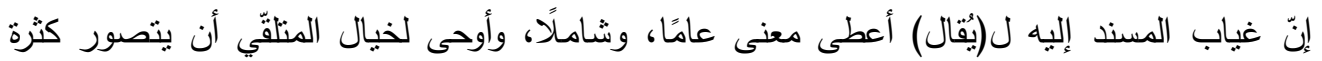

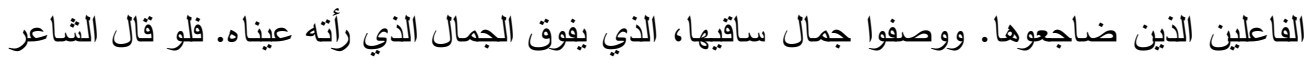

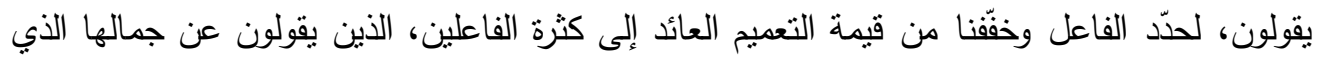
فاق الوصف، وبالتالي، ابتعد عن تحديد الرجال الذين قاموا بفعل المضاجعة. ولكن حين يغيّب الفاعل

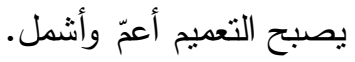


العدد الحادي والأربعون

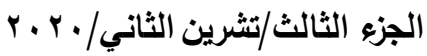

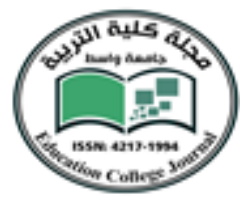

r- r إحكام بناء الصورة

قد يُحذف المسند إليه من أجل التركيز على أحداث المشهد، لأنّ غاية الثاعر تكون في إحكام

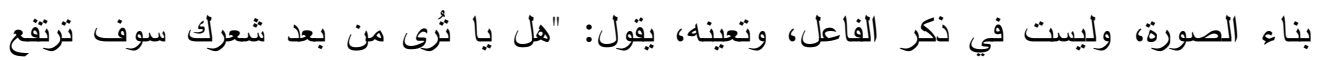

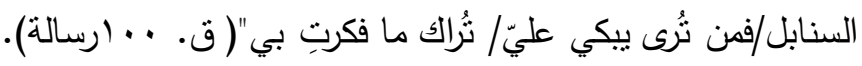

فمن ذا الذي يرى، وماذا يتوقع الثناعر؟ لا نعرف من قام بفعل النوقع، لذا حذف الثاعر المسند إليه

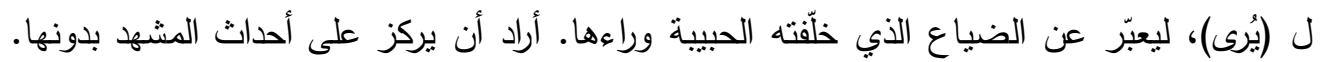
يشكّك بعودة الحياة إلى طبيعتها، وينساءل عن معنى الجمال من بعد الحبيبة، ومعنى الحياة بدونها،

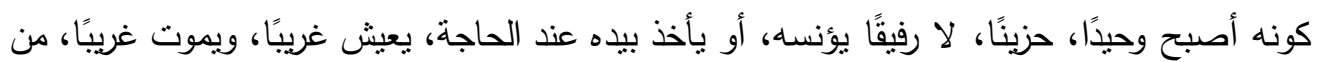

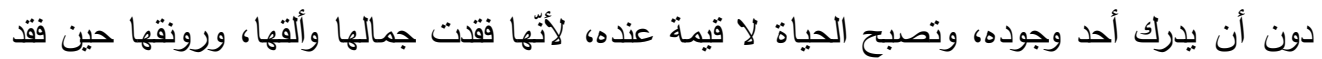

حبييته.

ومن منل هذه المقام يقول الثناعر: "هل صار زيت الجاز في بلادنا مقّسًا/ وصار للبترول في

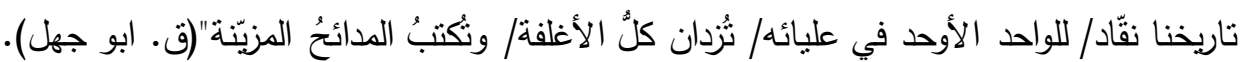

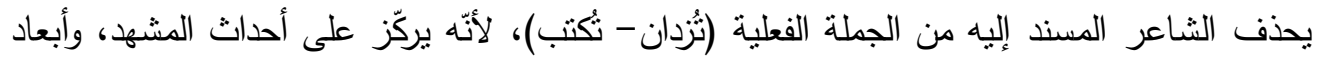
الصورة، فمن أجل الواحد الأوحد ثقام هذه الاحتفالات، وتهدر الأموال، وتُريّف الحقائق، ويُزوّر التاريخ، من يفعل كلّ هذه الأفعال، إن لم يكن هذا الواحد ذا سلطان قويّ جبّار، يضرب بعصاه الآداه

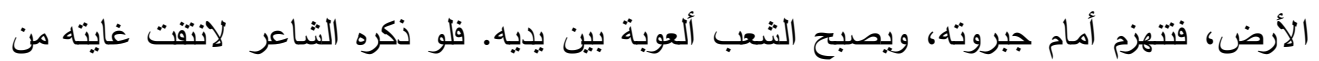
التركيز على مشهد هذا الواحد، ووحشية عمله.

\section{r - تأكيد علاقة الفعل بمفعوله}

يُحذف الفاعل لوجود علاقة بين الفعل ومفعوله، وقد تتحقّق هذه التقنية في باب المدح أو التهّمّ والسخرية، ففي مقام التهكّم، يقول: "أحاول رسم بلادي، تُسّىى مجازا بلادَ العرب"(ق. متى بعلنون وفاة

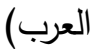

أخفى الثاعر المسند إليه من الجملة الفعلية (تُشمّى)، لأنَّه يثير السخرية والتهكّم، فالذي يُستّي بلاد

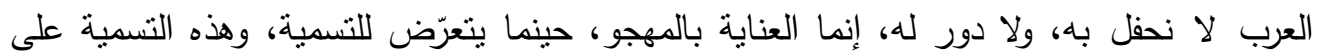
سبيل المجاز، وليست الحقيقة، لأنّ الحقيقة خلاف ذلك.

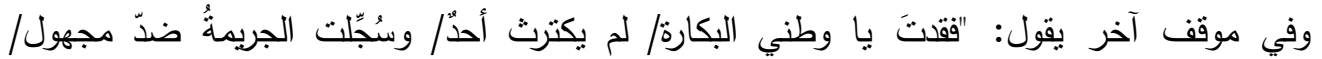

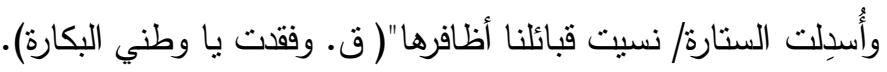


العدد الحادي والأربعون

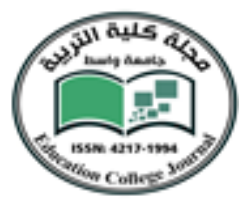

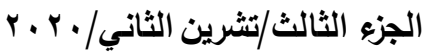

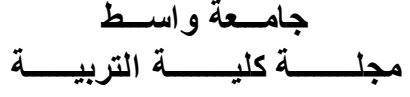

من الواضح أن حذف الفاعل هنا جعل العلاقة بين الفعل ومفعوله علاقة راسخة، فلو قال الثاعر إنّ التّا القبائل اغتصبت الوطن، وتسجلت الجريمة ضد مجهول، وأسدل المعنيون الستارة، لانتفى تحقيق

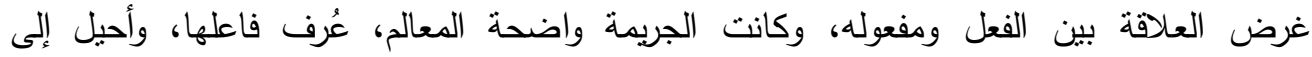

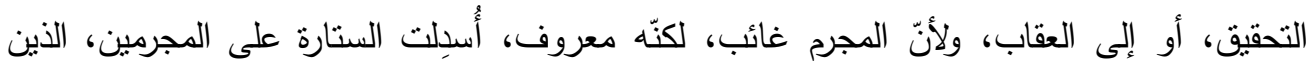

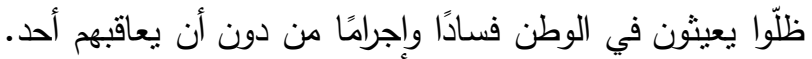

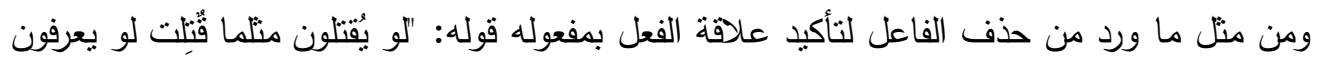

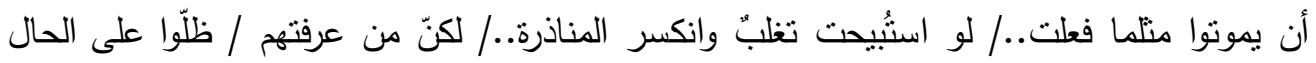

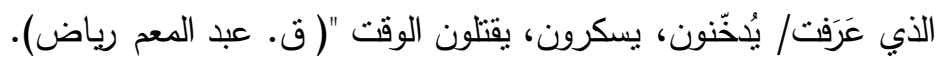
القاتل هنا معروف يُدرَكّ بالمخيّلة، وليس موجودًا بل محذوف، تقديره كلّ الذين تآمروا على عبد

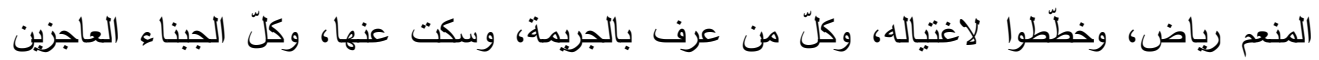
الذين هربوا من المواجهة، فهنا أكّد الثاعر علاقة القتل، وغيّب الفاعل لتتحقّق غايته من تلك العلاقة.

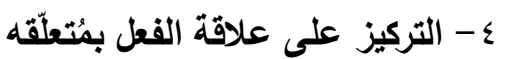

قد يُحذف الفاعل بهدف تركيز الاهتمام على علاقة الفعل بمتعلّه، لأن الثاعر يريد أن يجعل التفكير محصورًا بهذه العلاقة، ابتعادًا عن التثّتت الذهني، والذهاب بالتفكير إلى أمور بعيدة، يقول:

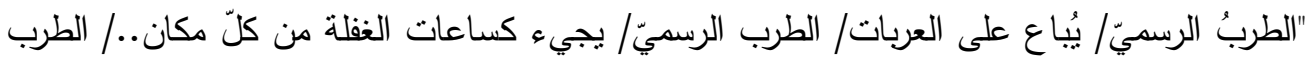

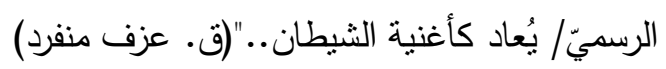
إنّ غرض الثاعر هنا ليس الفاعل بحد ذاته، إنما العلاقة بين الفعل (يُباع) وشبه الجملة الجار والمجرور (على العربات) المتعلقة به، ونلك لاحتقار عملية البيع، وطريقتها. وكنلك بالنسبة إلى حذف لاعن الفاعل في الجملتين التاليتين (يجيء كساعات الغفلة) و (يعاد كأغنية الثيطان) حذف الفاعلة الفاعل للتركيز على تلك العلاقة بين الفعل، وشبه الجملة، التي تمثلت في مقام السخرية والتهكّم.

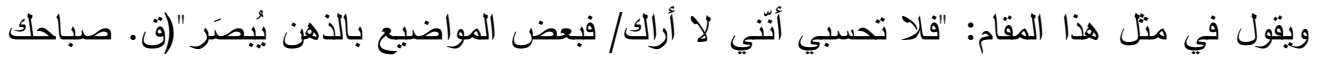

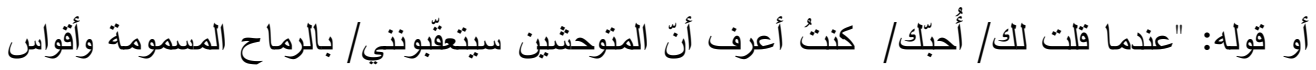

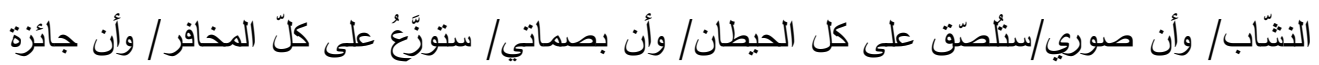

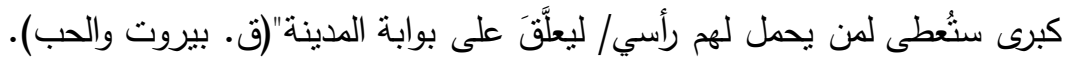


العدد الحادي والأربعون

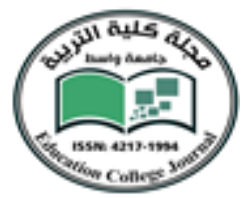

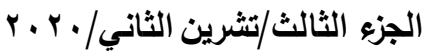

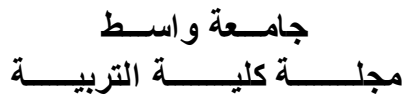

حذف الثاعر الفاعل لوجود علاقة بين الفعل (يُبصر) ومتعلقه (بالذهن)، ففي هذه العلاقة، يفخر

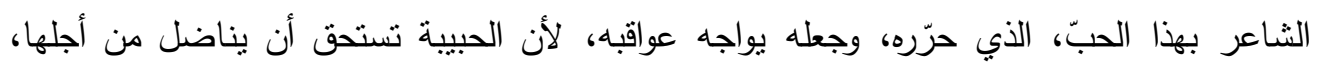

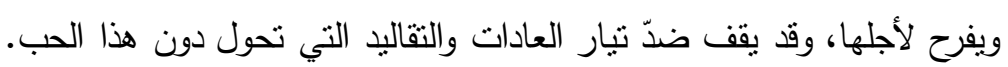
فمن باب الفخر دخل على تقنية الحذف، ولو قال أبصره بالذهب لخفّت هذه العلاقة، إذ من المككن

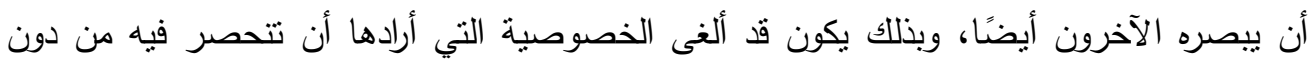
غيره.

والعلاقة بين (ستُلُصق) ومتعلقه (على الحيطان) وبين الفعل (ستُوزّع) وبين متعلقه (على كل المخافر)

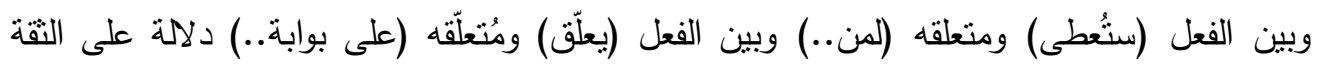
بالنفس، والتحذّي لخوض معركة شرسة، قوامها طرفان متعارضان، الحبيب الذي تصغر أمامه

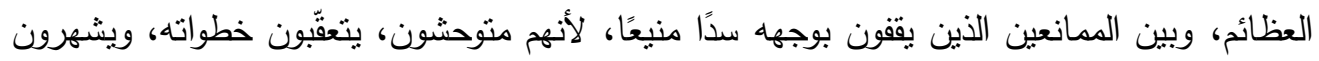

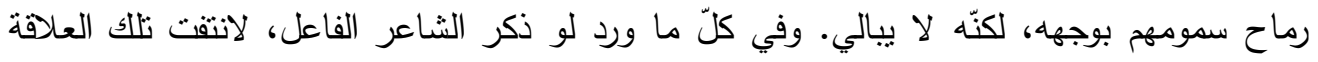
العميقة بين الفعل ومُتعلّقه. ه- الإيحاء بعظمة الموقف

يقول الثاعر : "لا ترفع الصوت/ فأنت آمن../لا تناقش أبدا مسدسًا/أو حاكما أو فردًا../كن بلا

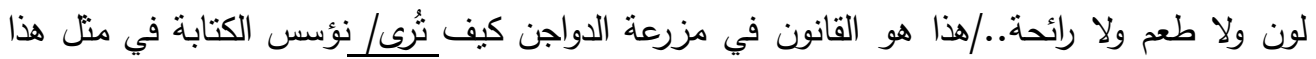
الزمن الصغير"(ق. أبو جهل). لحذف الفاعل في (ترى) مساهمة قوية في تأكيد الايحاء بعظمة الموقف، فالشاعر يخاطب الاسكندر

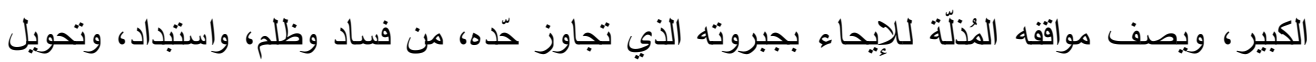

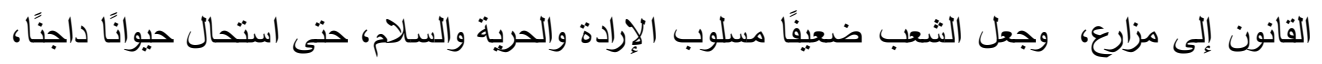

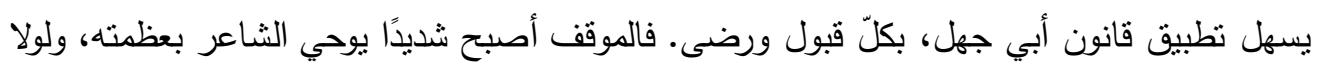

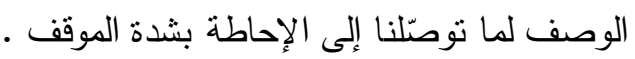

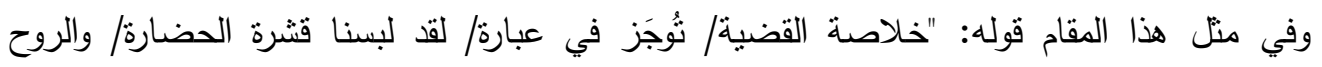
جاهلية"(ق. هوامش على دفتر النكسة). من ذا الذي أوجز هذه العبارة ؟ لقد غيّب الثاعر الفاعل في (توجز) للتأكيد على ما تضيفه على التى

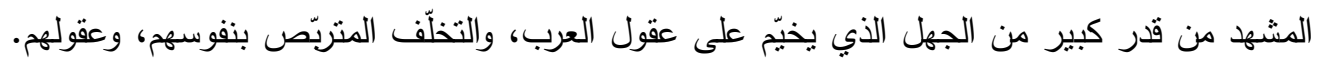

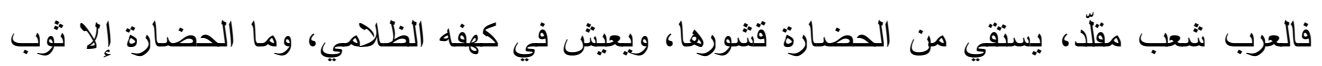


العدد الحادي والأربعون

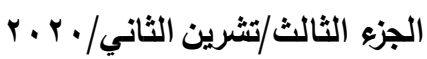

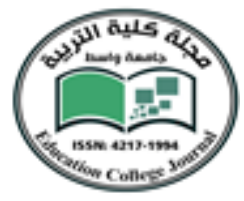

مزيف تختبئ فيه تلك الروح الجاهلية، لذا من السهل أن يحذف الثاعر المسند إليه، ويركّز على الموقف الذي أوحى إليه. - اليه فلو ذكر الثاعر الفاعل الذي يوجٍز العبارة لاستثنى مِن الأعراب مَن هم في مقام رفيع من الفكر والعقل الوقاد، وهذا ما لا يعنيه، لأنه يخفّف من جلال الموقف، وعظمته، ويجعل المشهد قريبًا من إدراك المتلقي مفهوم الحضارة. 1 - تعميق دلالة النفي في الفعل

لحذف الفاعل في هذا الدقام أثر كبير في تأكيد الدلالة وتعميقها يقول: "أريد أن أهديك كنوزا من

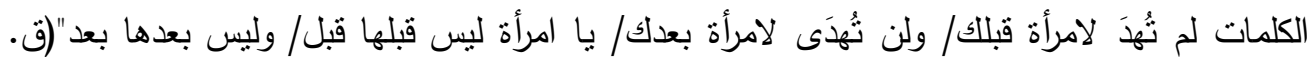

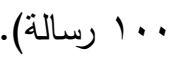

المسند في أهديك معروف، وقد ذكره الثاعر لأنه يعود إليه(أنا) أهديك ليميز نفسه عن الآخرين،

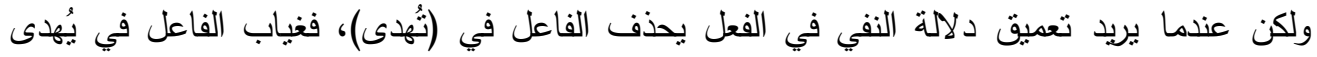
جعل النفي مسلّطا على الفعل، ليفيد نفيه على وجه الإطلاق. فلو قال يهديك الشعراء لكان من الممكن أن تعجب بكلمات الشعراء أكثر منها إعجابًا بكلماته، وجعل نفسه في مقام الآخرين، وهذا ما لفا لا يريده، إنما أراد أن بحصر الجمال، وكنوزه فيه وحده من دون الناس جميعًا، فالهية التي يهديها

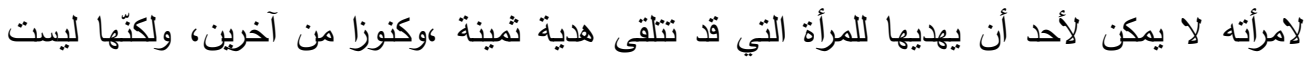
بقيمة هديته أو بحجمها، أو بمدلولها.

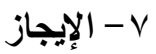
الإيجاز تقنبة معروفة متحقّة في كلّ أنواع الحذف، وقد تكون في بعض الحالات كأنّها الفائدة،

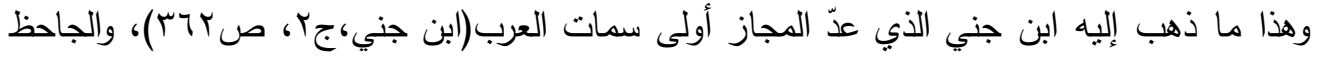

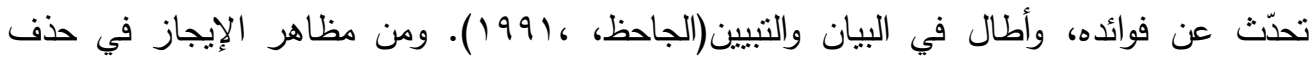

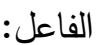
1 - حذف الفاعل للعلم به. يقول: "وهي بمهذها نُبَح عن الكلمات/ وعن آلاف الثشيدات دُفنّ بغير أسماء/ بمقبرة النقاليد" (ق. حوار مع يدين ارستقراطيتين). ذكر الثاعر عبارة ثُدبح، وقد حذف الفاعل منها، ولكن في العبارة الأخيرة ذكر النقاليد

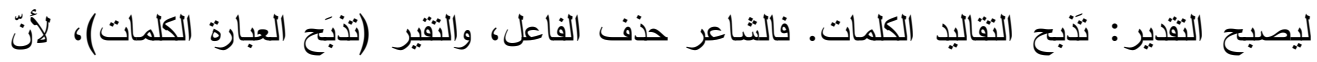

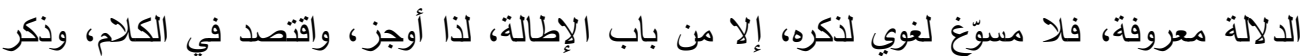

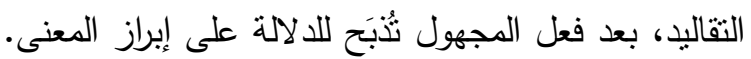


العدد الحادي والأربعون

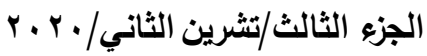

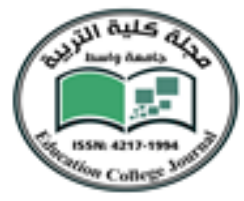

r- حذف الفاعل لسابق ذكره في السياق يقول: "شكرا لكم/ فحبيبتي قُتَتَ وصار بوسعم/ أن تشربوا

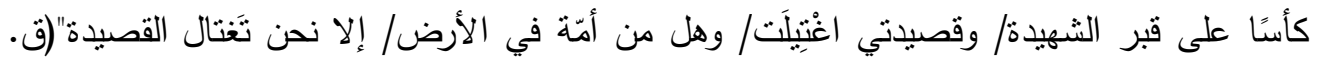
بلقيس). حذف المسند إليه أي الفاعل في (قُتلت) و (اغتيلت) لأنّه أراد التعميم، فالقتل والاغنتال قام به

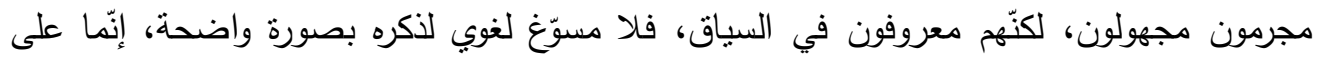

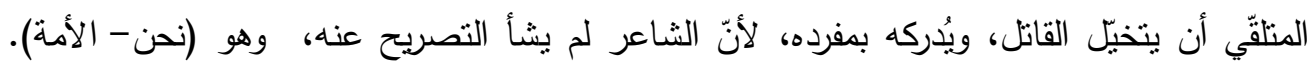
وهذا الحذف يدخل في باب الإيجاز والاختصار . ثاثثاً - حذف المسند في الجملة الاسمية

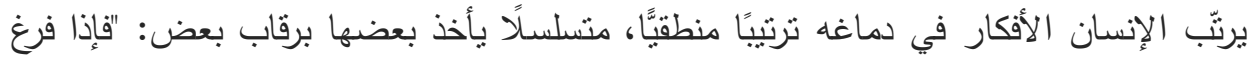

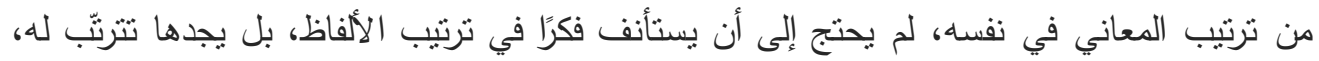

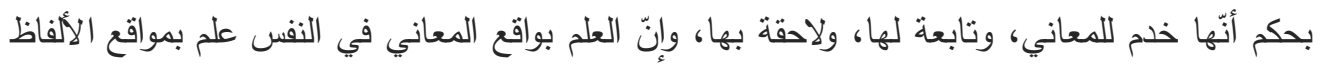

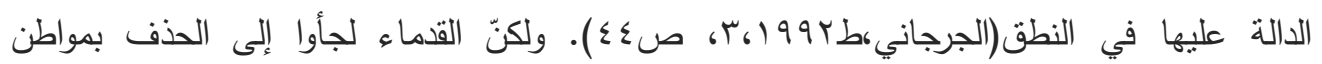
عديدة، وردّوا المحذوف ضمن ما يفرضه المنهج النحوي من غير البحث عن القيم الجمالية المنتبّة

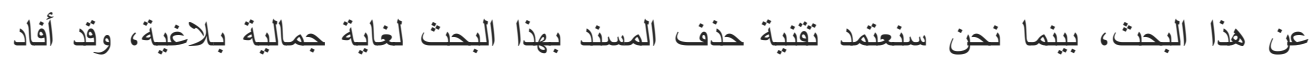
حذف الخبر في ديوان الثاعر فوائد كثيرة منها: 1- الإيحاء بنفي المبتدأ

المبندأ اسم صريح، ومؤول بالصريح، يأني في بداية الجملة الاسمية، ويليه الخبر، بإسناد الخبر

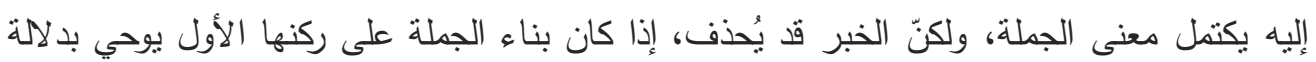

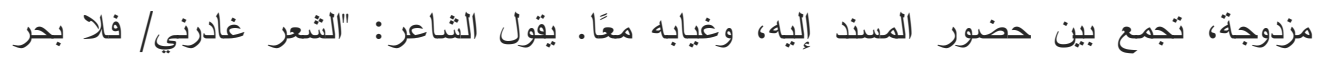

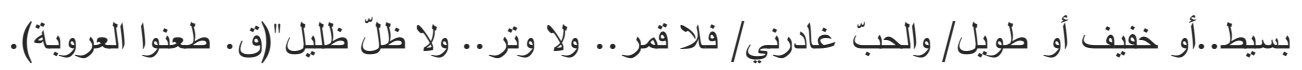

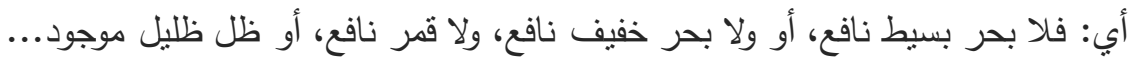

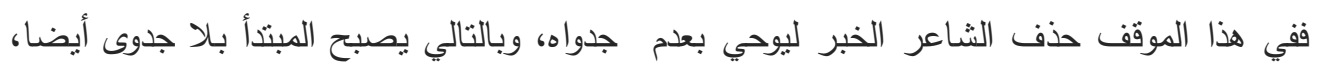

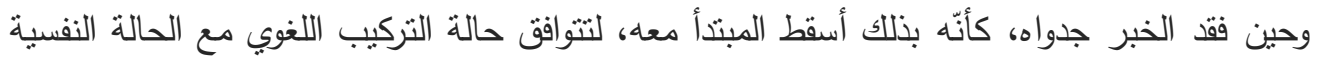
للثاعر فلا جدوى من شيء كون الأهم بالنسبة إليه غادره.

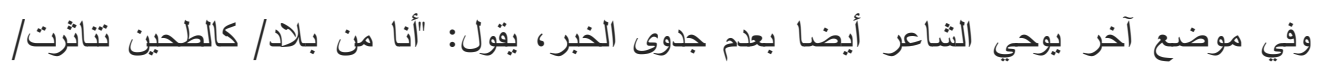
مزفًا/ فلا ربّّ.. ولا توحيدُ"(ق ـ طعنوا العروبة). 
العدد الحادي والأربعون

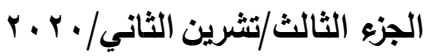

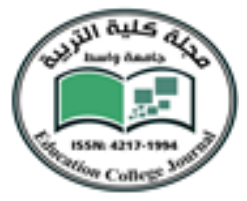

أي: أنا من بلاد نتاثرت مزقًا، فلا ربّ بحمي أو يدافع أو يقي، ولا توحيد نافع. لذا حذف الثاعر

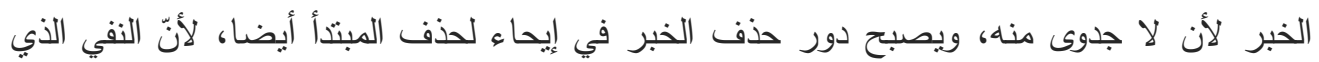
حقّه حذف المسند أوحى بحذف المبندأ معه.

r- تجسيد صفة المبتدأ

تحت ثأثثير الانفعال يُقتّم الثشاعر كلامًا بني على المبندأ، لا تسنطيع اللغة أن تقدّم له خبرًا،

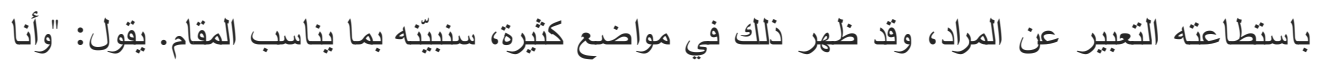

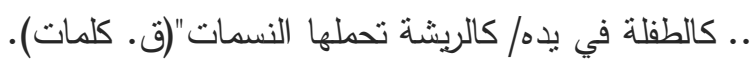

حذف المسند من الجملة أي خبر المبتدأ (أنا) محذوف، وكان افكان لحذفه فائدة في تجسيد صفات المبتدأ، فأنا بريئة، خفيفة، ولأنّ الثاعر لم يجد كلمة جامعة لهذه الصفات حذف المسند، وجعل الجار

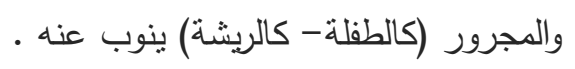

كما يقول: "لماذا نكلّفين صوتلك/ أن يغتالني مرّة أخرى/ إنتّي رجل ميّت/ والميّت لا يموت مرتين/

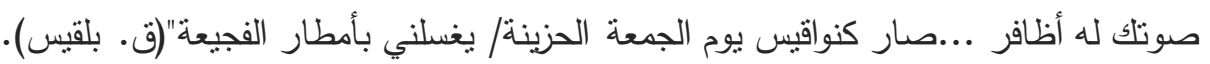
التقدير: صوتك قوي جارح حزين فاجع أو غير نلك. فالصفات التي تسنطيع التعبير عن التأثير السلبي الذي يتركه صوتها في نفسه كثيرة، لذا حذف المسند (الخبر) في هذا السياق، وأستبدله بصورة الأظافر والنواقيس. ويقول أيضًا: 'قلبي، كمنديل سفر/ كطائر/ ظل قرونًا ضائعًا تحت المطر"(ق. الدخول إلى الى هيروشيما). الثقدير: قلبي (طائر) كمنديل سفر أو غير ذلك يلوح على سبيل المثال. حذف الثاعر المسند

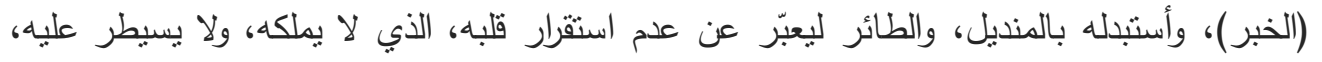
لأنّّه حرٌ طليقُ لا قرار له ولا موطن. r- تعميق بناء الصورة الفنية

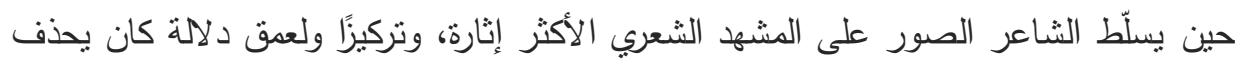

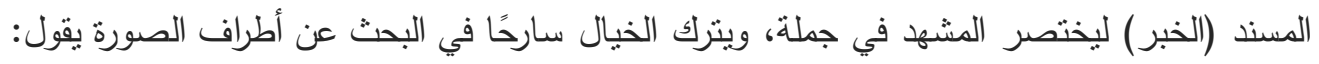

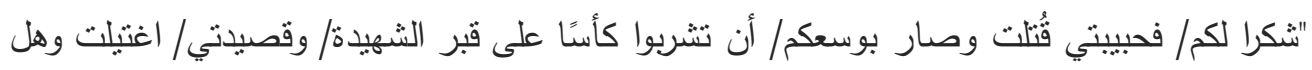

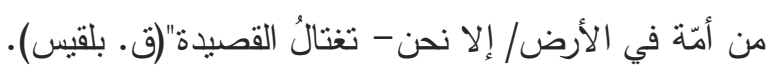

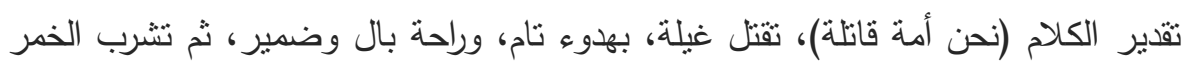

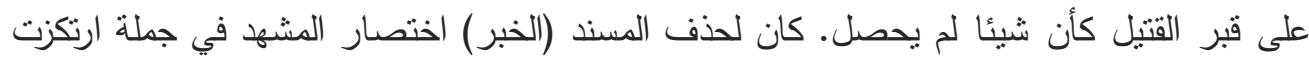


العدد الحادي والأربعون - (العي

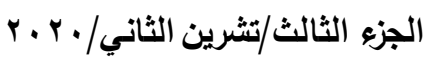

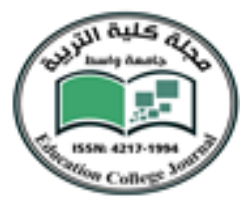

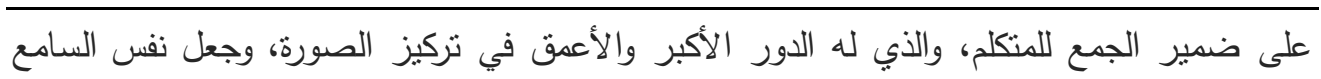
حرّة في تخيّل مقدار الجرم الذي ترتكبه الأمّة في حقّ أبنائها.

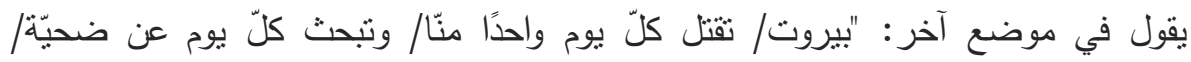

$$
\text { والموت../ في فنجان قهوتتا/ وفي مفتاح شقتّتا/ وفي أزهار شرفنتا" (ق . بلقيس). }
$$

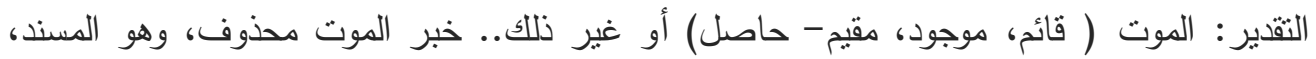

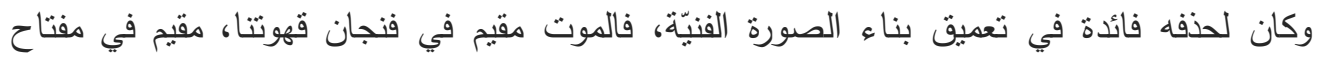

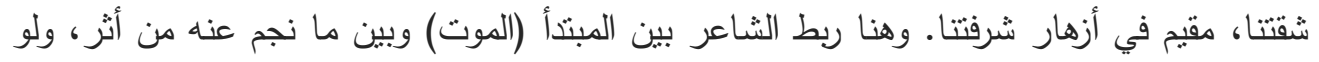
ذكر الخبر لضعفت قوّة الربط بين الطرفين، وبالتالي خفّت الصورة الشعرية.

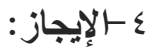

قد يحذف الثاعر المسند (الخبر) تلبية لإسراع الأحداث أو الصورة التي نتوارد في ذهن السامع من مثل قوله: "بلقبس/ فلكلّ دبوس صغير قصدّة/ ولكلّ عقد من عقودك قصتان" (ق .بلقبس).

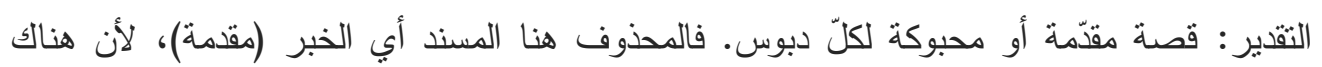
علاقة بين المبندأ والمدذوف (الخبر) لوجود ما سدّ مسذّه الجار والمجرور، وفي ذللك اختصار الكلام

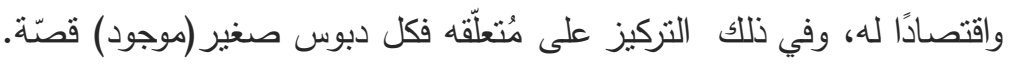
رايعاً - حذف المسند من الجلمة الفعلية

قد يُحذَف المسند من الجملة الفعلية لأغراض كثيرة منها: حذف الفعل وحده، عندما يكون الفاعل منفصلًا عنه، وكان يحمل حذف الفعل قيمًا بلاغية عديدة. وقد يحذف المسند والمسند إليه معًا، فيدخل في نطاق حذف الجملة التي يبقى في السياق، ما بدلّ البّل

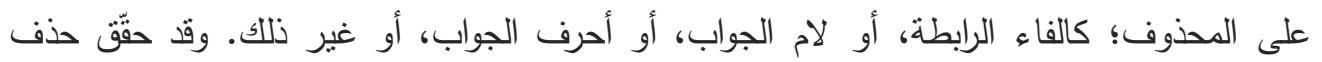
المسند في الديوان فوائد كثيرة منها: 1 - المعتق دلالة الموقف الوجداني

أحيانا الموقف الوجداني الذي يكون فيه الثاعر يدعوه إلى حذف المسند أي (الفعل) من الجملة

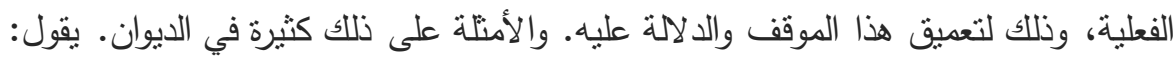
"حتى الطيور تثرّ من وطني/ ولا أدري السبب/ حتى الكواكب والمراكب/ والحبّ حتى الدفاتر "(ق. رسالة من نتحت الماء) . 
العدد الحادي والأربعون

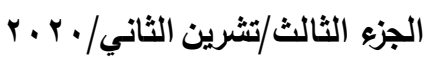

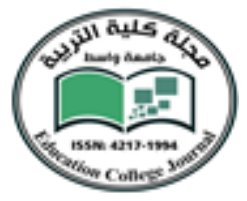

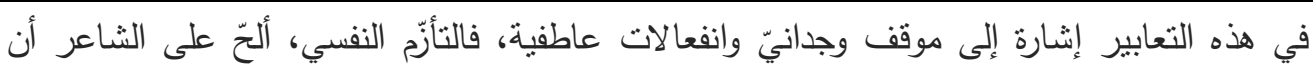
يرسم مشهر سوداوي، وصورة مأساوية، فيلجأ إلى حذف المسند حتى الكواكب والمراكب والحب لفي (تفرّ) حنى الدفاتر (تفرّ) تلبية لذلك الموقف يسيطر على الثاعر الشعور باليأس والألم والحسرة. لذا غيّب الفعل (تقرّ) ووجّه الأبصار إلى التركيز على صورة المسند إليه، فنراه يذكر الفعل مرّة واحدة، ويتعمّد إخفاءه مرتين، كي لا يتوه ذهن السامع

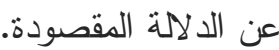

فالقيمة في هذه العبارة ليست للمسند بل للمسند إليه (الكواكب، والمراكب، والحب، والدفاتر )ليشير إلى

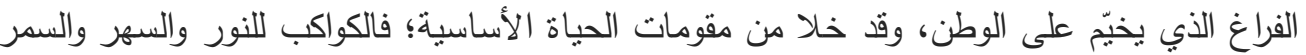
والراحة والفرح. والمراكب لحركة الناس، وعملهم وذهابهم وإيابهم وهذا يدلّ على الحياة والازدهار والثقّم والنطوّر المستمرّ . والحبّ دلالة على الالفة والتعاون والعائلة وترابط المجتمع. والدفاتر دلالة على التقدّم العلمي والفكري والثقافي. وحين حذف الثاعر الفعل كان هدفه التركيز على الفاعلين، لأنهم الأهمّ في ذهنه من الفعل

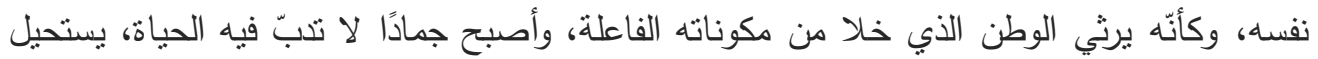
أرضًا قاحلة جامدة ميّتة لا نبض فيها، وبالتالي يفقد قيمته وهويته ومكانته.

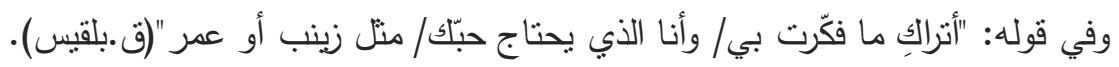

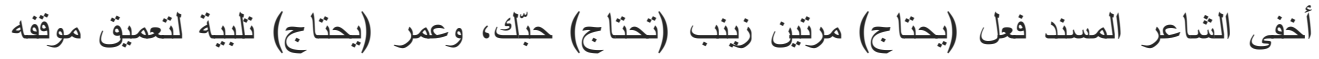

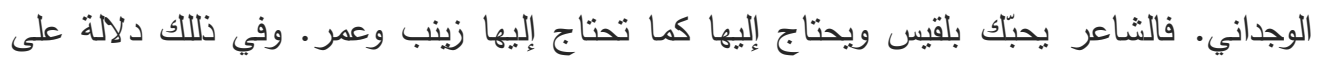

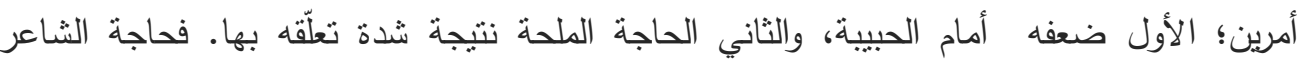
لحبيتها وتعلقه بها حالة ثابتة راسخة ومؤكّة، لا ريب فيها. لذا يدلّ حذف الثاعر المسند فعل (يحتاج) على تعميق موقفه الوجداني، فعلاقة بلقيس بزينب وعمر

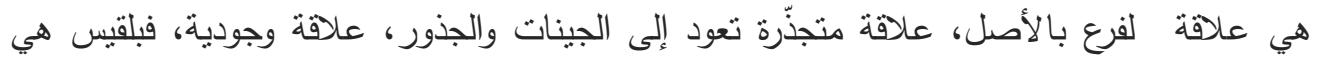

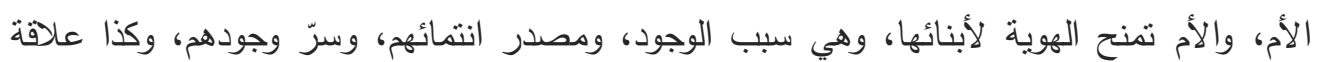
نزار بالحبيبة علاقة وجودية، وعلاقة أمومة وعلاقة هوية وانتماء.

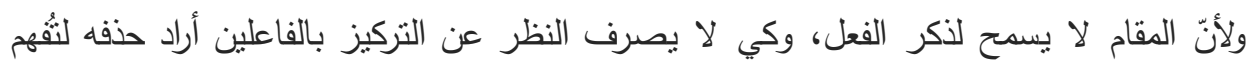

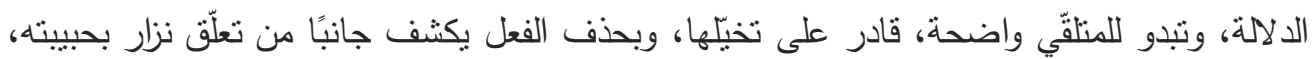

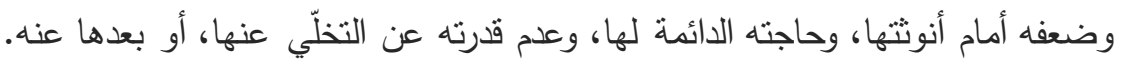


العدد الحادي والأربعون

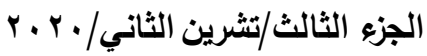

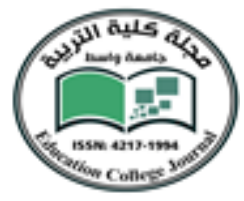

وفي موضع آخر يجسّد الحذف للفعل حالة من الاضطراب الداخلي، والثنكّ المستمرّ الذي يزداد

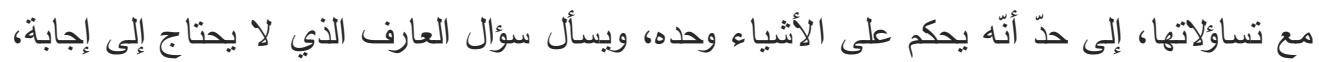

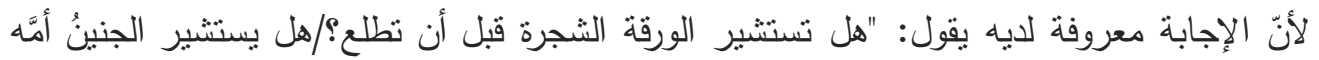

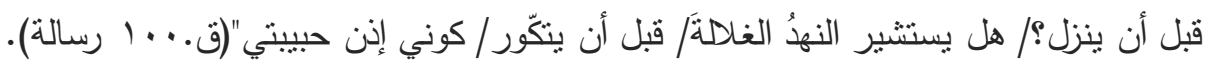

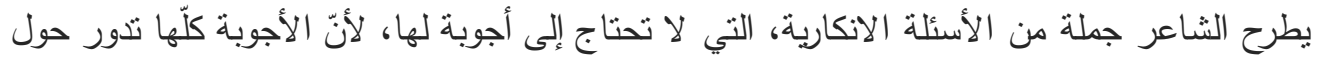

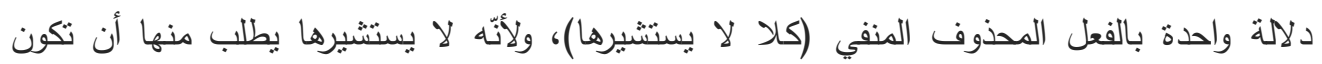

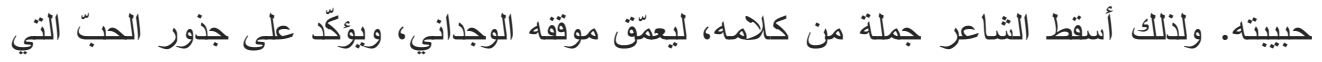
لا يمكن أن تضطرب إزاء رياح التقرقة العاتية. وفي موضع آخر يقول: "كميس الهوادج.. شرقية/ ترشّ على الثمس خُلو الحِدا/ كدندنة البدر فوق سرير "(ق. ورقة إلى القارئ). التقدير: (تسير) كميس الهوادج. من خلد الموقف نعرف أن المسند المدذوف يدلّ على هدوء

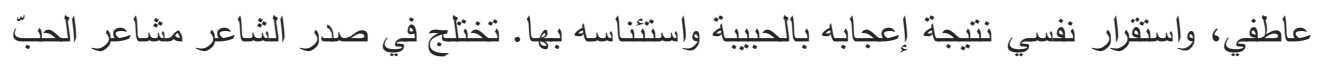

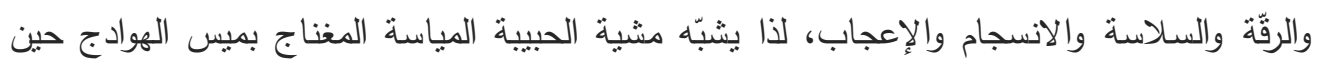
تسير، ولكي يلفت انتباه السامع إلى تلك المشية حذف المسند (تسبر) وحصر نظره عليها، ليظلّ لفئل

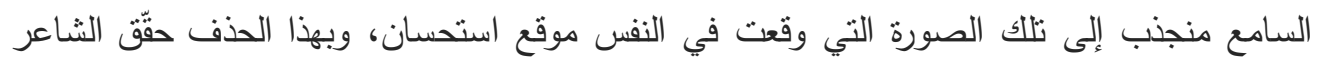

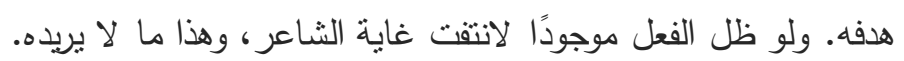

\section{r - توجيه الغناية إلى مُتعلقّات الفعل}

في مواقف كثيرة يمنع المقام الثاعر عن الإطالة للوصول إلى المقصود، لأنّ الإطالة قد تعيق

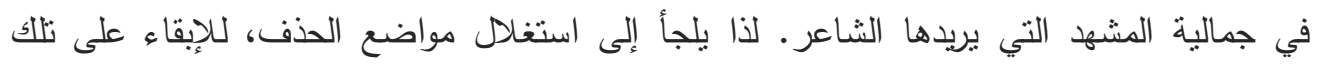

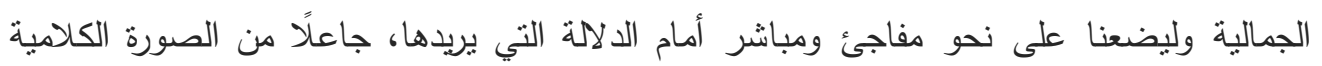

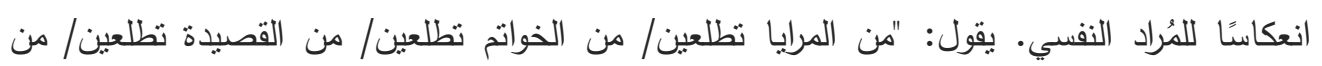

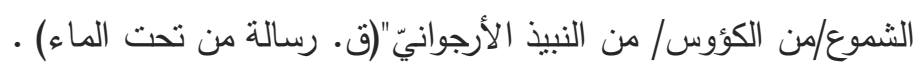
الأصل في الجملة من الثموع(تطلعين)، من الكؤوس (تطلعين) ومن النبيذ (تطلعين).

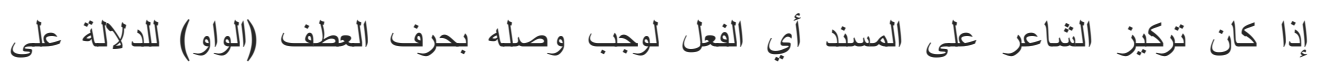
المشاركة والمصاحبة، وبذلك للنع التكرار. غير أنّه حذف المسند للتركيز على ما بعده، وتوجيه

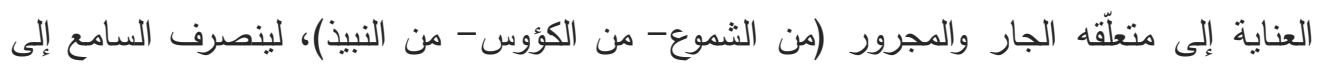


العدد الحادي والأربعون

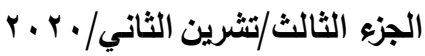

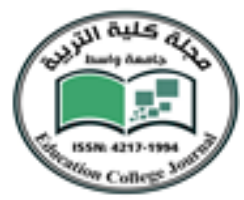

تصوير المشه على الكؤوس والثموع والنبيذ، للالالة على أنّ الحبيبة تقيم في خبال الثاعر ، ثقبم في كلّ ما يدور في خلده، وبذلك يرسم لون الفرح، والراحة، والسمر ، والرومنسية، والحبّ.

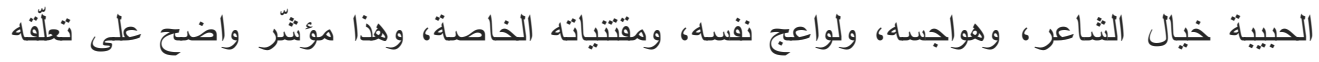
الثديد بها، ورفضه لفقدانه لها، وعدم تقبّل فكرة غيابها. فلو كرّر المسند نطلعين لمال عن غايته نحو غاية أخرى وهذا ما لا يريده. ومن منل قوله: "اسكتي يا شهرزاد/ أنت في وادٍ وأحزاني بواد"(ق. حوار مع امرأة)

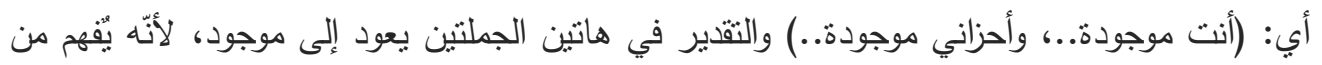

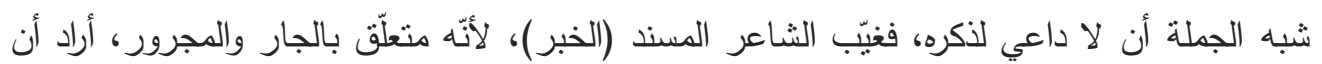
يوجّه العناية إلى هذه المتعلقات.

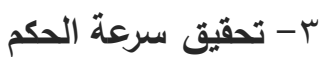

أكثر ما تبرز هذه التقنية في أسلوب الثرط، لأنّ الترابط شديد بين جملة الثرط وجوابه، لذا

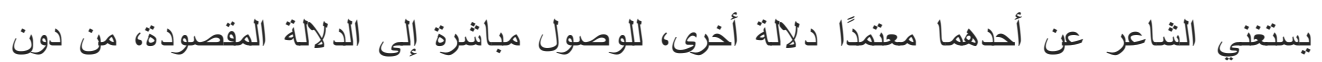

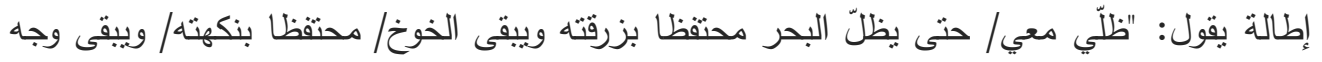

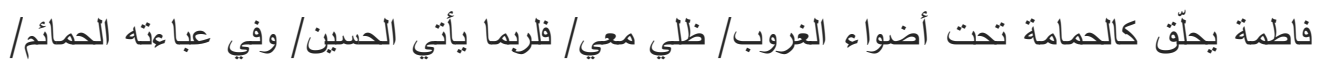
والمباخر والطيوب"(ق. آخر عصفور يخرج من غرناطة).

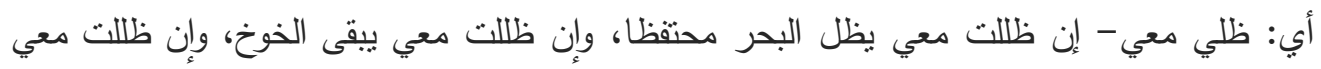

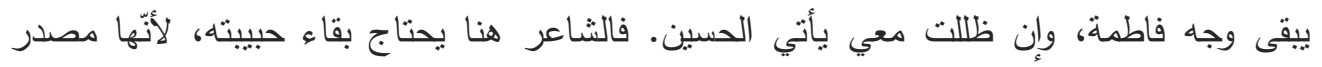

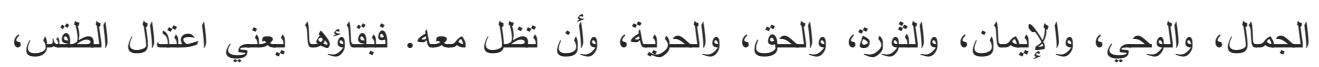

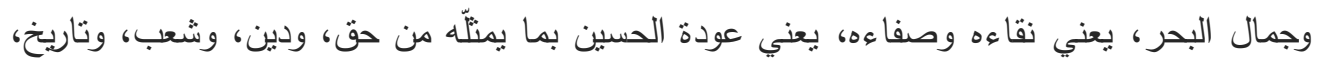
ونصر ، وبقاء وجه فاطمة متعلّق بوجود الحبيبة معه.

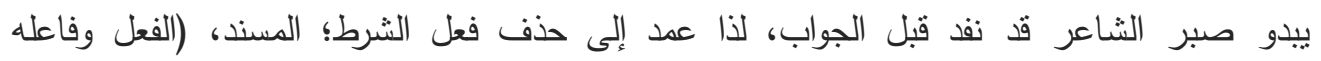

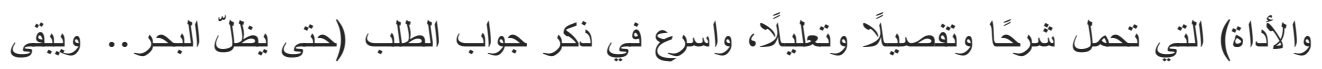

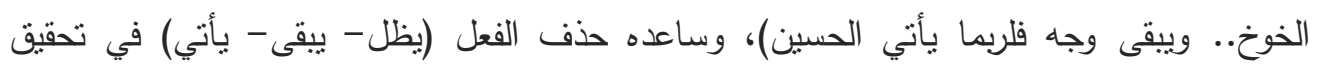
مراده. ويقول في مقام آخر : "اخرجي من شراشف سريري/ اخرجي من فناجين قهوتي../ اخرجي من

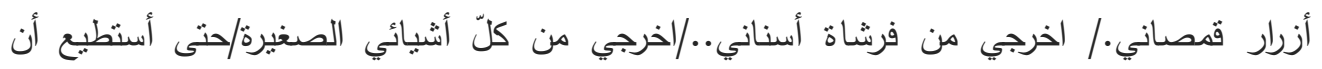
أذهب"(ق. رسالة حب). 
العدد الحادي والأربعون

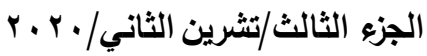

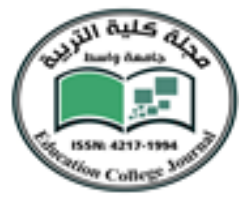

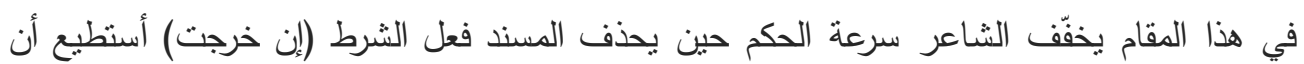

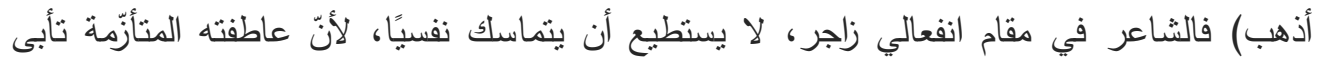
السيطرة على نفسه، ولأنّه لا يملك الصبر ، استعجل في ذكر جواب الطلب (حتى أسنطيع الذهاب) وحذف الأداة، وفعله، وساعده حذف الفعل في تحقيق مراده.

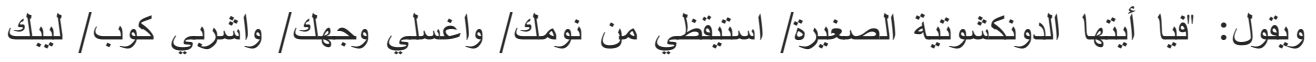

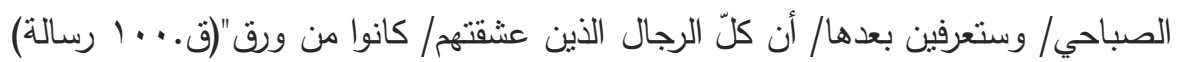

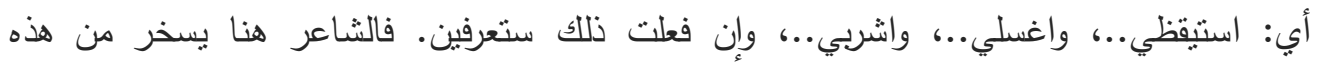

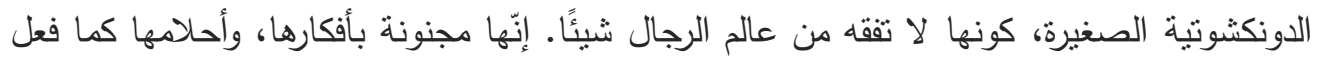
دون كيشوت. مسكونة بأفكار وهمية.

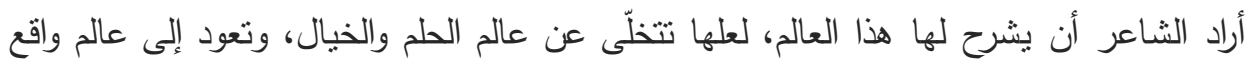

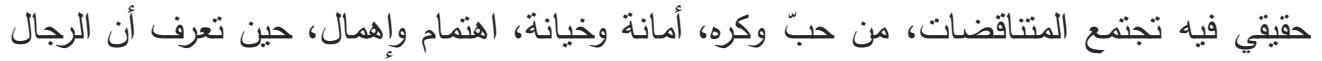
ليسوا تلك الصورة النقية التي ترسمها في خيالها، بل هم طبيعيون، حقيقيون واقعيون.

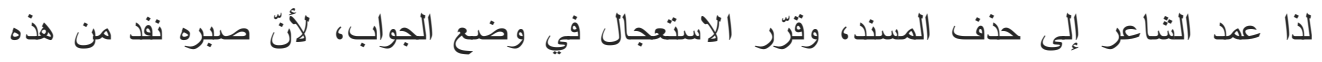

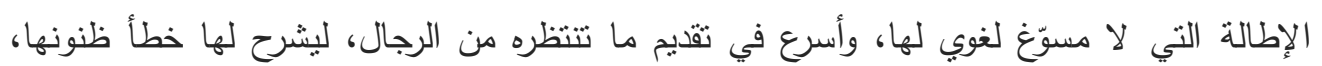

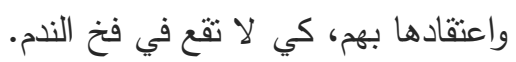
وفي مكان آخر يقول: "لا تسألوني ما اسمه حبيبي/ أخشى عليه شوعة الطيوب..// لا تبحثوا عنه هنا بصدري/ تركته يجري مع الغروب"( ق. لا نسألوني ما اسمه حبيبي).

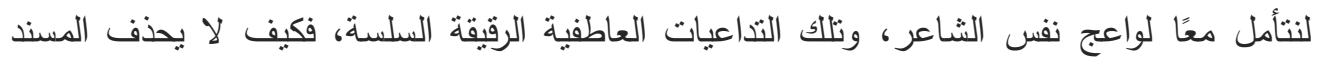

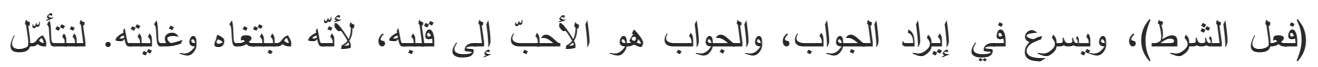

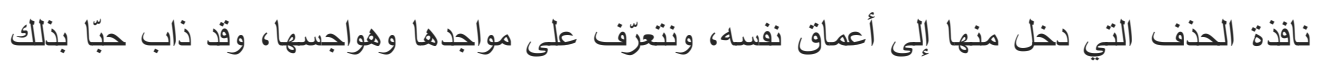

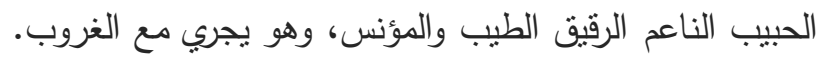

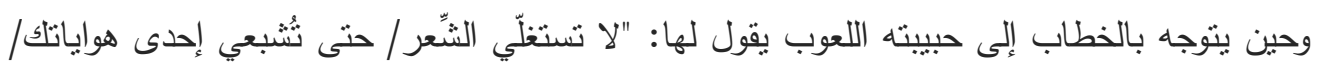
فلن أكون راقصًا محترفًا"(ق. إلى امرأة لا مبالية).

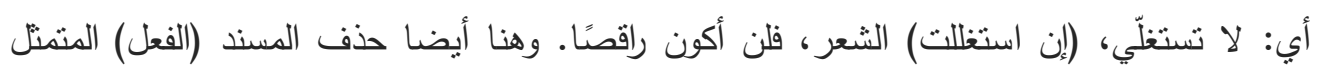

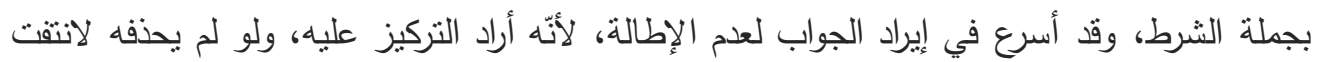

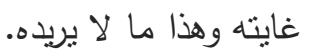


تحدثّا عن حذف المسند في الجملة الفعلية، وتبيّن أنّ الثناعر لجأ إليه لضرورات بلاغية، أراد

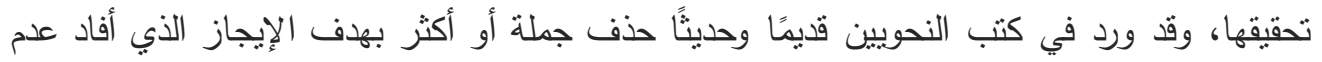

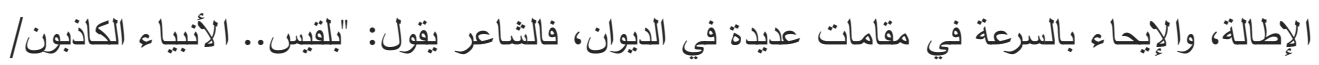
يُقْرفصون/ ويركبون على الثعوب/ ولا رسالة"(ق. بلقيس).

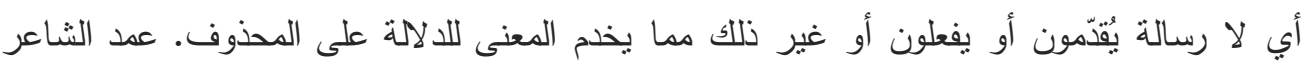

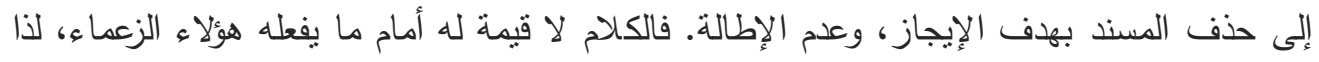

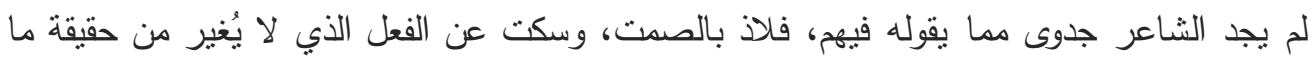
يرى شيئا. ويقول في موضع آخر: "إليّ اكتبي ما شُشتِ.. إني أحبّه/ وأنلوه شعرا/ وما بك ترتابين؟ هل من

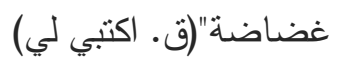

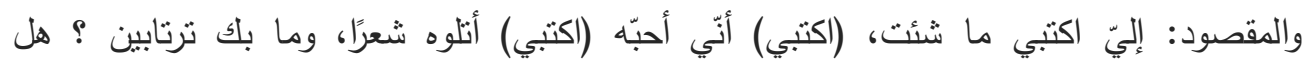

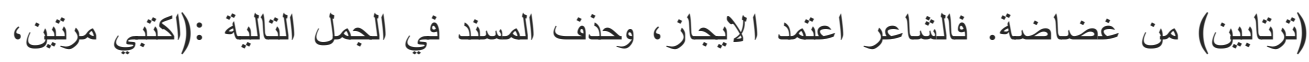

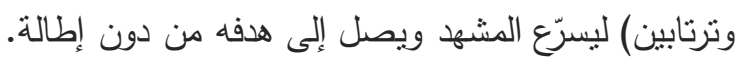

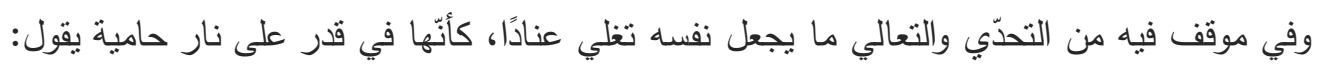

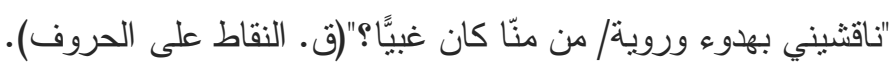

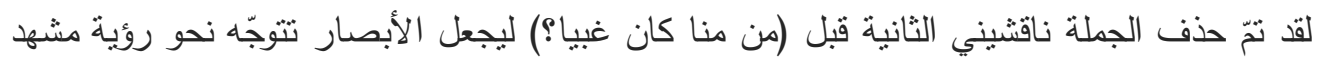

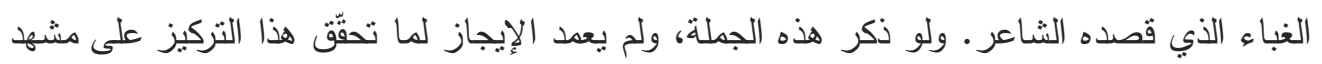

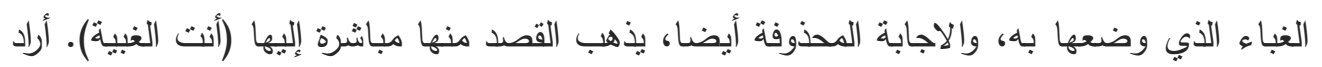

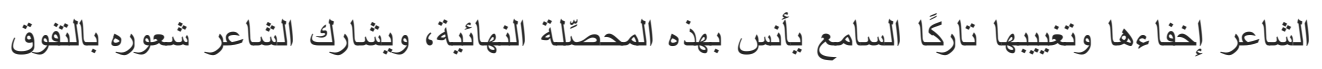

خامسًا - حذف جملة أو أكثر

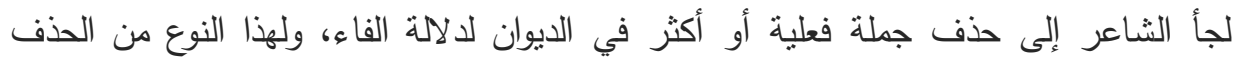

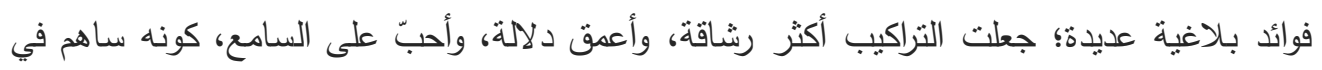

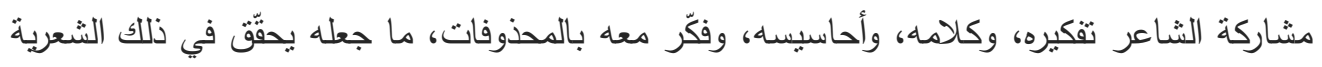

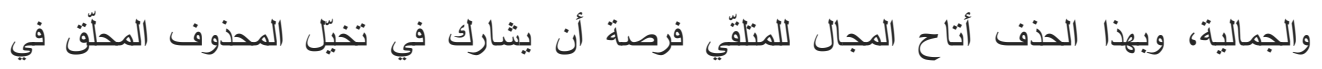

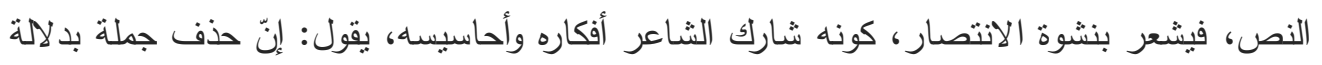


العدد الحادي والأربعون

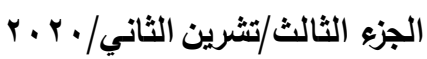

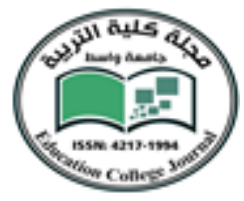

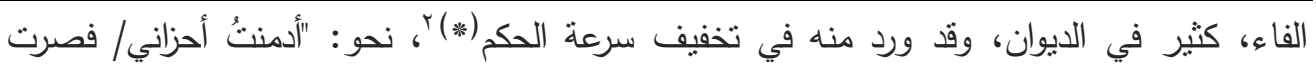
أخاف أن لا أحزنا"(ق. أدمنت أحزاني). المقصود أدمنت أحزاني (لأنتي أدمنت أحزاني) فصرت أخافت ألخاف. حذف الثاعر الجملة التي لها دور

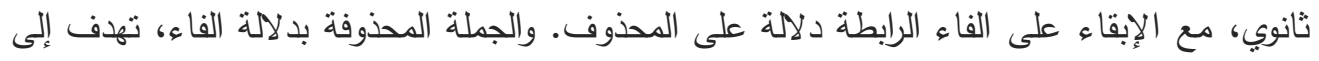

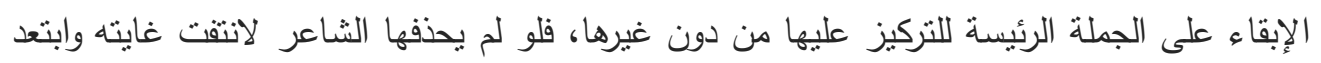
عن مراده وهذا ما لا بريده. ويقول في موضع آخر : "أحبّك برقًا يُضيء حياتي/ وقنديل زيتٍ بداخل صدري/ فكوني صديقة

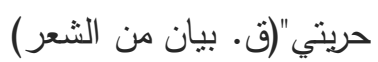
أي: أحبّك برقًا.. أحبّك قنديل زيت.. (لأنتي أحبّك)، فكوني صديقة. استخدم الثاعر أسلوب الثرط،

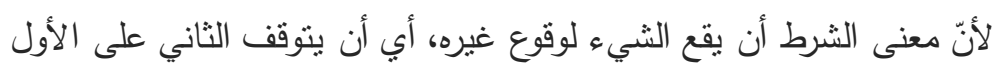

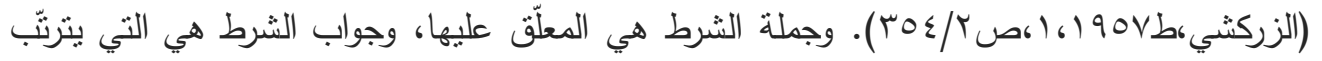

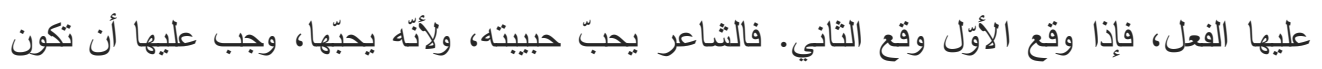

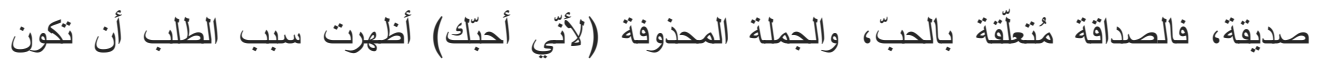
صديقة. وقد حذفها الثاعر بدلالة فاء الجزاء.

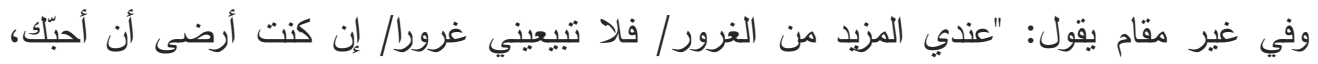

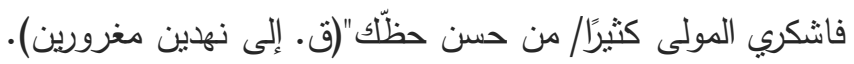

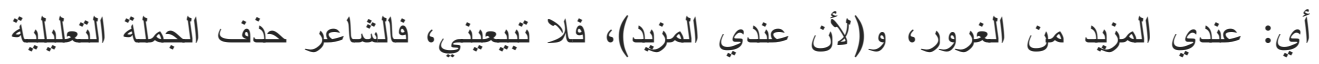

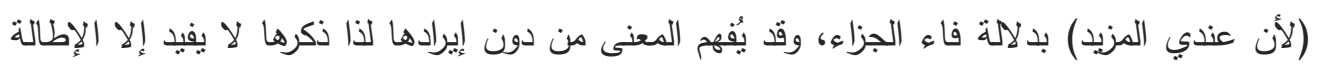
وهذا ما يريده الشاعر.

كما يقول: "طالبت ببعض الثمس/فقالوا رجال الثرطة:/قف يا سيد بالطابور "(ق. الطابور).

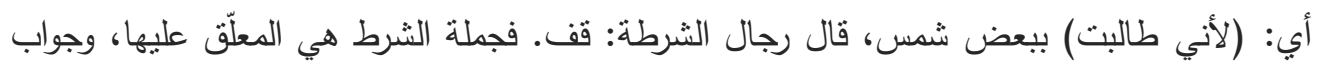

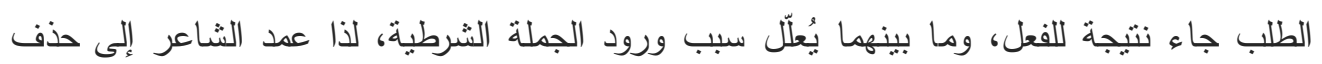
الجملة التعليلية، لأنّ السياق مفهوم من غير ذكرها، وهي سبب الطلب ولا حاجة لذكره.

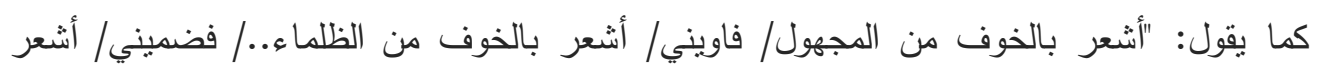
بالبرد فغطيني" (ق. جسمك خارطتي).

r(\%) - ورد نكر من مثله ص ^^ تحت عنوان تحقيق سرعة الحكم، وركزنا على حذف المسند من دون غبره، ونحن لا نقصد النكرار ، إنما أردنا إظهار جمالية الحذف لما هو أكثر من المسند، أي حذف جملة أو أكثر. 
العدد الحادي والأربعون

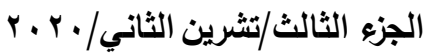

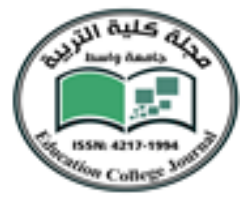

تقدير الكلام أشعر بالخوف، (لأنني أشعر) فاويني.. فضميني.. فغطيّي. يشعر الثاعر بالخواء الروحي، في مقام الضعف والخوف، لا يملك القوة لمواجهة الحياة من دون حبّها وحنانها واهتمامها به. لذا لم يكن الدقام العاطفي يسمح بإيراد الجملة التعليلية التي تسوّغ حاجته إليها وشعوره بها، وتظهر سبب الطلب، فحذفها لعدم الإطالة، وسّرع في الطلب. وبالتالي يكون حذف الجملة قد ساهم في تحقيق هدفه.

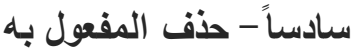
وقف عبد القاهر الجرجاني عند الحذف المفعول وقفات طويلة، ورأى أنّ الغاية منه تكمن في

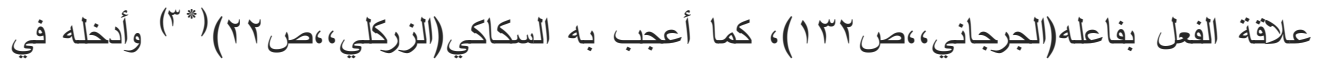

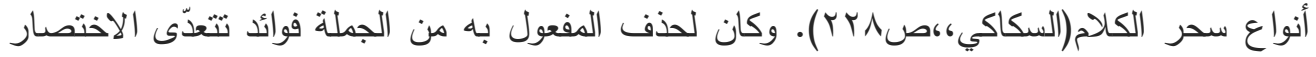
والإيجاز ، وقد وقف نزار قباني عند هذه الفوائد، وهي على الشكل الآتي: 1 - التركيز على العلاقة بين الفعل وفاعله ولانه أراد الشاعر أن يقتصد في الكلام، ويختصر الجملة الفعلية على ركنين أساسيين هما؛ الفعل وفاعله، لذا لجأ إلى حذف الركن الثالث لعلاقة بين الفعل وفاعله، وتكمن فائدة حذفه بعدم تشنّت ذهن

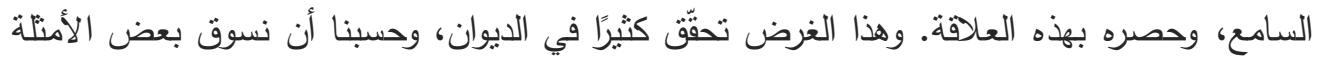

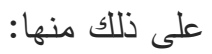
في مقام الألم والفجيعة يقول: "غيرّي الموضوع با سبدتي/ قهوتي فيها غبار / لُغتي فيها غبار / إنتّي أكتبُّ منل الطائر المذعور / ما بين انفجار وانفجار "(ق. حوار مع امرأة) .

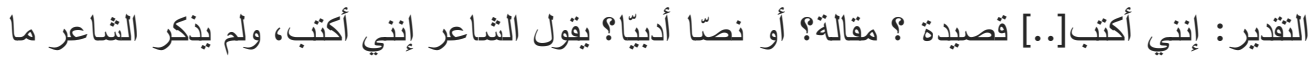

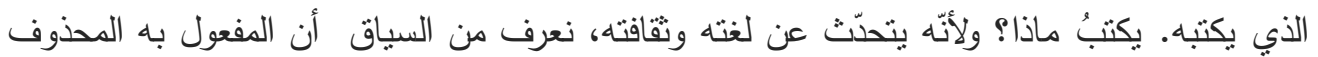

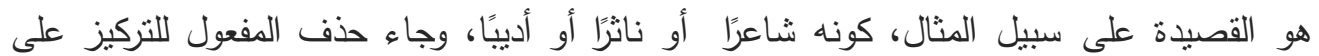
علاقة الفعل بفاعله.

كما يقول في موضع آخر : "تزتعشين أمامه كفأرة مذعورة/ وترمين صورة ماو على الأرض..||

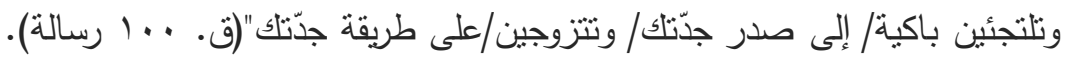

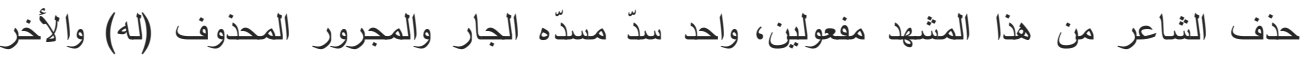
(الرجل) للأفعال (تلتجئين، وتنزوجين).

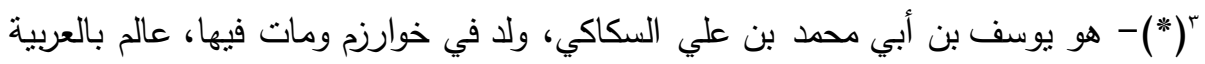

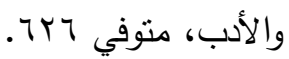


العدد الحادي والأربعون

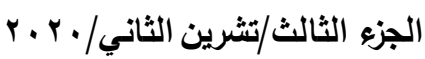

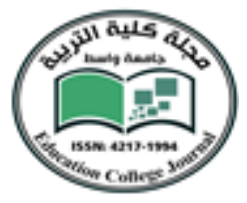

إن الغاية من الحذف إبراز علاقة الفعل بفاعله والفاعل (هي) فالتركيز عليها (هي) وعلى ما تقوم به الهيه من أفعال، للالالة على ضعفها، وعدم قدرتها على المواجهة، وعجزها عن تحرير نفسها من العادات الموروثة الني تعيق تقدّم المرأة وحصولها على حقوقها الاجتماعية والإنسانبة.

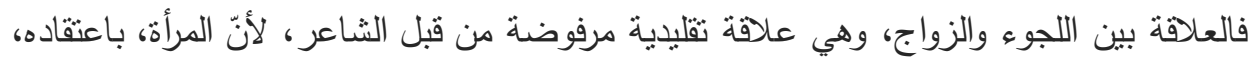

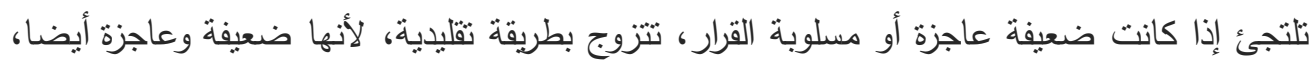

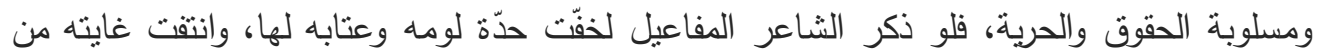
التركيز على تلك العلاقة بينها وبين ما تقعل، وقد يفهم السامع من لجوئها إلى الرجل وزواجها منه

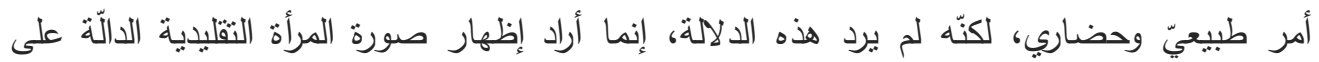
الخوف والضعف والعتاب. أدّى حذف الثاعر للمفعولين غايته في تركيز العلاقة بين الفعل وفاعله.

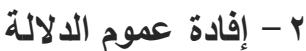

لجأ الثاعر إلى حذف الدفعول لتعميم الدلالة، وتقويتها، وقد ورد هذا النوع كثيرًا في الديوان

$$
\text { يقول: "لي أنت مهما صنّف الواشون، مهما جرّحوا"(ق. أنت لي). }
$$

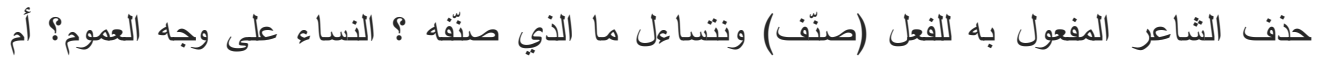
الجميلات منهنّ؟ خفيفات الظلّ، القاصرات، الراثدات؟ عمد الثاعر إلى حذف المفعول به، لأنّه من المحتمل أن يكون الواشون قد صنفّوا النساء، كلّ النساء

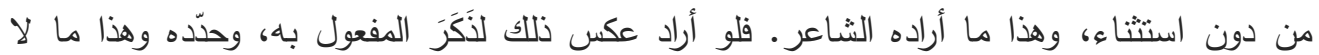
يريده، لأنّ غاية الثاعر في ذلك تعميم الدلالة، وتقوية الدعنى أكثر . ويقول في مقام آخر : "لماذا تخابرين.. يا سيدني/لماذا تعتدين عليّ بهذه الطريقة المتحضّرة"(ق.... رسالة).

حذف الثاعر المفعول به للفعل (تخابرين). ولم يقصد أنها تخابر أحدًا بعينه، ولا يريد أن

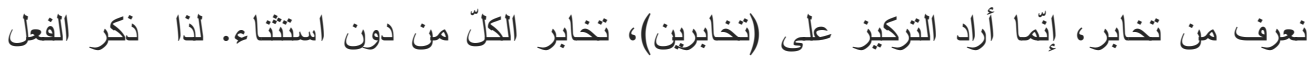

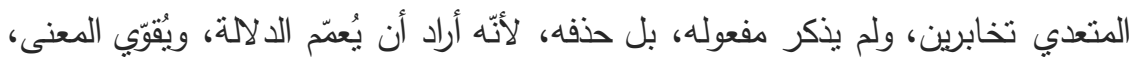

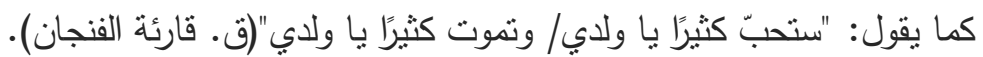
الثقدير ستحبّ من؟؟ زوجتلك حبيبتك، ابنة الجيران، صديقة. ركّز الثاعر على الحب وفاعله، وأهل

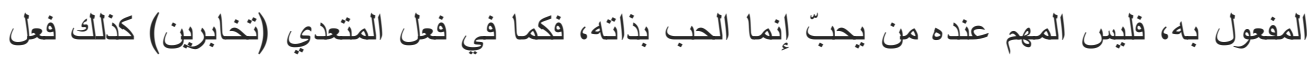
(ستحبّ)، حذف الثاعر المفعول به، لأنّه أراد أن يعطي المعنى قوّة، وعمومية أكثر . 


\section{العدد الحادي والأربعون

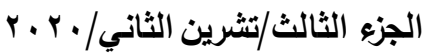

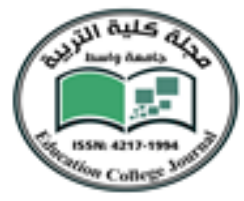

وفي موضع آخر يقول: "لقد مزّ عشرون عاما علينا/ وليس هنالك حزن/.. وأهل السياسة لا يقرأون

$$
\text { ولا يكتبون"(ق. النقب) }
$$

لم يذكر الثاعر المفعولين للفعلين (يقرأون - يكتبون)، بل نركها للقارئ يستتنج أنّ الساسة لا يقرأون

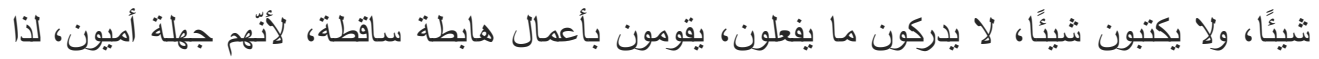
حذف المفعولين (كتبًا- مقالات) وغير ذلك لتحقيق الفائدة المرجوة من هذا الحذف، وهي إفادة عموم الدلالة، وإعطاء المعنى قوّة. ب - تعميق العلاقة بين الفعل ومُتَعَّقهه

قد يعدد الشاعر إلى حذف المفعول به بهدف تعميق العلاقة بين الفعل ومنعلّقه، لأن التركيز ينحصر بهذا المتعلّق وليس بالمفعول، لأنّ غيابه قد يؤدّى إلى إبراز هذه العلاقة على أكمل وجه

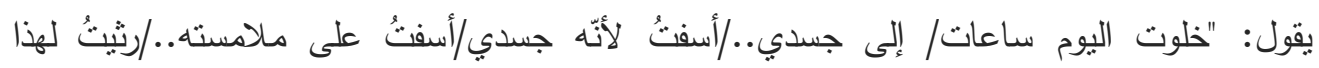
الوحش/ يأكلُ من وسادته/ لهذا الطفل" (ق. يوميات امرأة لا مبالية). حذف الثاعر المفعول به لفعل (أكل) وركّز على متعلّّه (من وسادته). يتحدّث عن جسده في ساعة تأمّل، يأخذ خلوة لساعات ينابعه، يعاينه، يصفه، يذكر أفعاله، وغايته ولونه، يصل إلى رثائه، فيقول

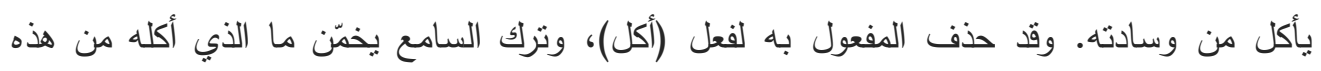
الوسادة، لكنّ الثاعر يهمل المفعول به، ويعد إلى إزالته لأنّ غايته من الفعل منصرفة إلى (من الوسادة). وليس إلى ما أكله، وبذلك يعمق العلاقة بين الفعل (أكل) ومتعلقه (من الوسادة). وفي موضع آخر يقول: "كنت أفرح بصوتلك/عندما يخرج من سماعة الهاتف/ كعصفور أخضر/

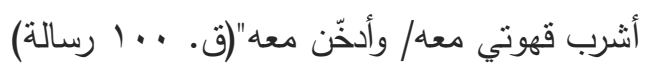

حذف المفعول به لفعل (أدخّن) وذكر منعلقه (معه). والتقدير أدخّن (السيجارة- النرجيلة) ، وغير ذلك، معه. وقد أدّى غياب المفعول به إلى إبراز العلاقة بين الفعل ومتعلّقه، لأنّ المراد من الكلام قيل بوساطة تلك العلاقة. ع - الإيحاء بسرعة الأحداث

إنّ حذف المفعول به للإيحاء بسرعة تعاقب الأحداث، وتواليها غاية دقيقة اعتمدها الثاعر في ديوانه، يقول في مقام السخرية والهجاء: "سأقول في التحقيق/ كيف غزالتي ماتت بسيف أبي لهب/ من الخليج إلى المحيط/ يدمرون../ ويحرقون../ وينهبون/ ويرتشون/ ويعتدون على النساء/كما يريد أبو لهب/ ويأكلون/ ويسكرون"(ق. بلقيس). 
العدد الحادي والأربعون

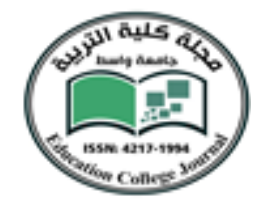

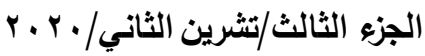

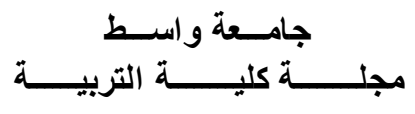

التقدير : ( يدمرون البيوت، يحرقون البلاد، ينهبون الخيرات، يأكلون الأرزاق أو المال أو غيره بريد أبو

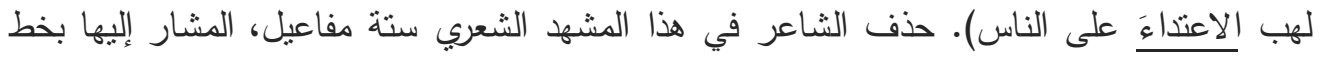

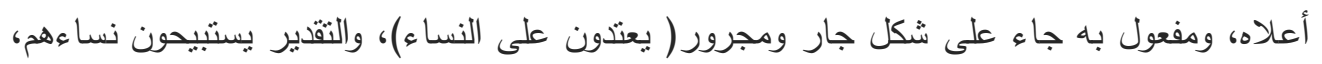
وخمسة (يدمرون، يحرقون، ينهبون، يأكلون، يريد).

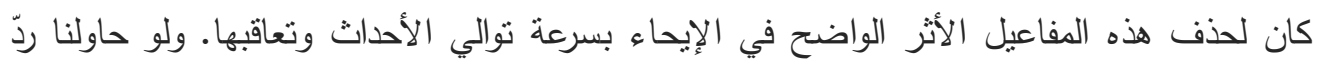

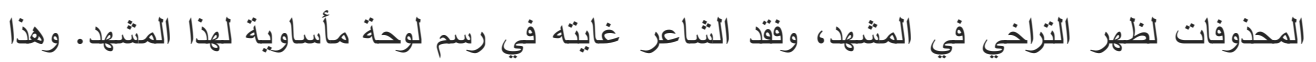
ما لا يريده الثاعر. كما يقول في موضع آخر : "لو قرأوا - يا سبدي القائد- ما كتبت/ لكنّ من عَرَفْتَهم/ظلاوا على الحال

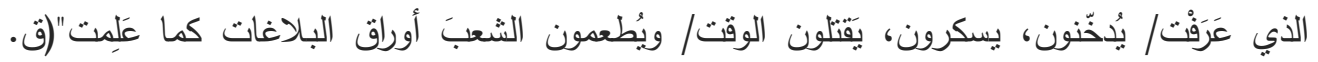

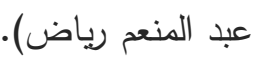
حذف الثناعر مفاعيل الأفعال (عرفت، يُخخنون، عِلتِ). والتقدير يُعرف من السياق(عرفت

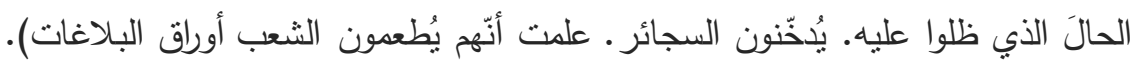

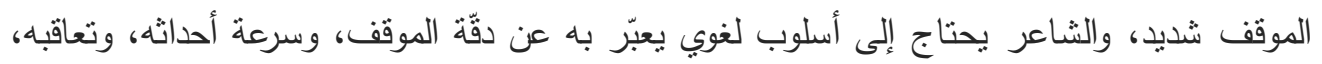

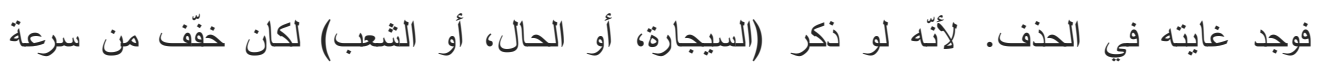
الأحداث. المتتالية، وهذا ما لا يريده.

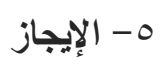

وهي غاية عرفها البلاغيون قديمًا وحديثًا، يلجأ الثشاعر إلى حذف الدفعول به بهدف الإيجاز لأن

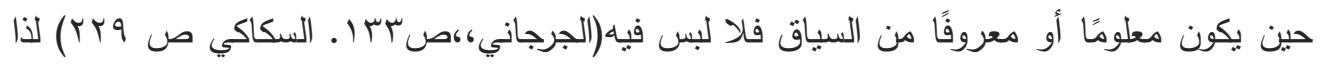

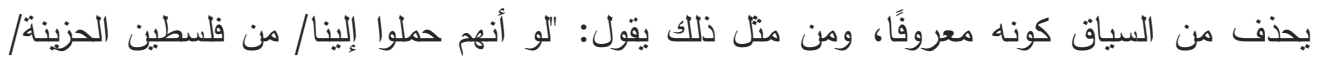

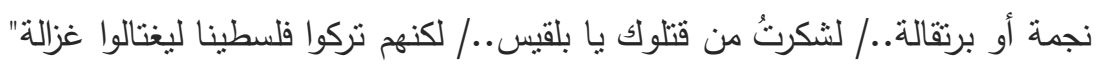

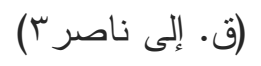

النقدير: نركوا فلسطين ليغتالوا امرأة غزالة. حذف الثاعر الدفعول به لفعل يغتالوا، واستبله في

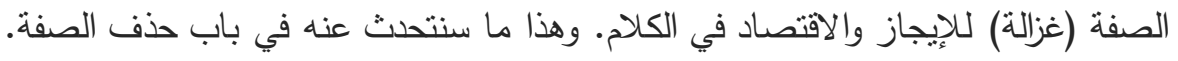

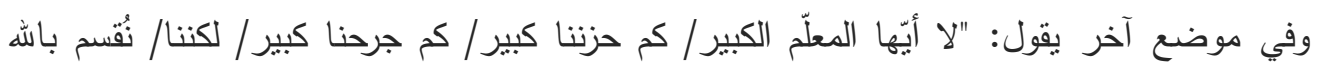

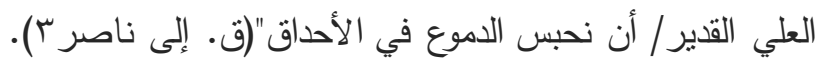


العدد الحادي والأربعون

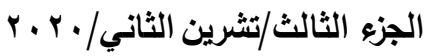

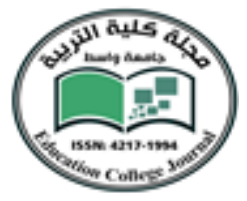

أي نقسم يمينًا بالله. حذف الثاعر المفعول به (يمينًا) من باب العلم به، فالمفعول معلوم، تدلّ عليه العادة اللغوية، كما يوحي به السياق فلا فائدة من ذكره، ولو ذكره الثاعر لاتنقت غايته من الإيجاز ، بالهال وهذا ما لا بريده.

وفي مقام آخر يقول: "والجند في سطح السفينة يشتهون ويسكرون/ فرغن براميل النبيذ ولا يزال الساقطون، ينوعدون"(ق. رسالة جندي في جبهة السويس). تقدير الكلام يشتمونهم، ويتوعّدنهم. حذف الثاعر مفعولين به من هذه العبارة، لأنّ الدلالة واضحة

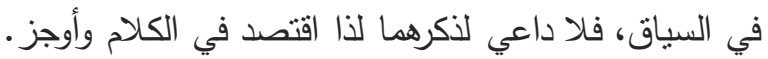

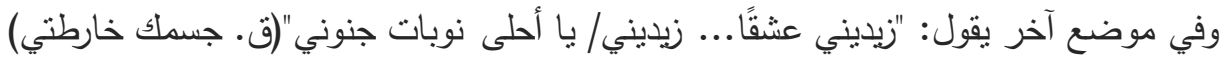

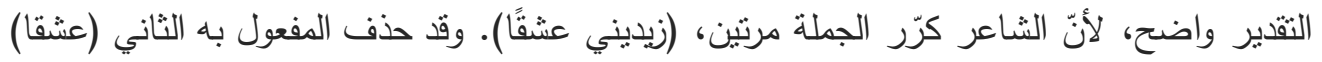
من الجملة الثانبة بهدف الإيجاز، والاقتصاد في الكلام، كونه معلومًا من السياق الأوّل، فلا داعي لهي ل الذكره مرة ثانية.

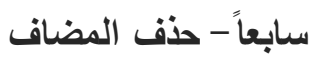
انشغل الكثير من البلاغيين في مناقثة بلاغة حذف المضاف تحت قضية الحقيقة والمجاز، وهل

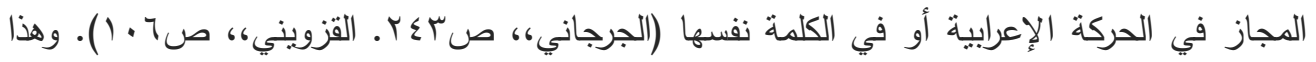

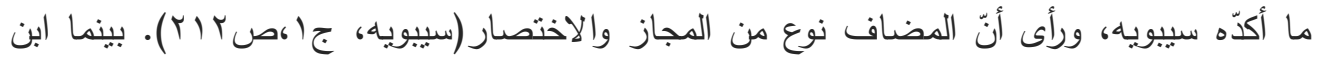

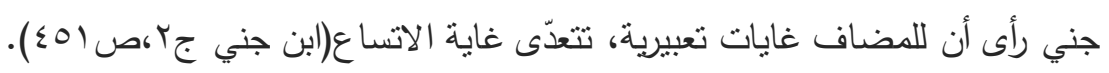

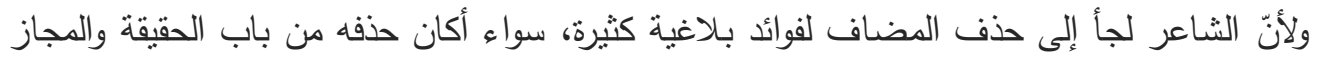

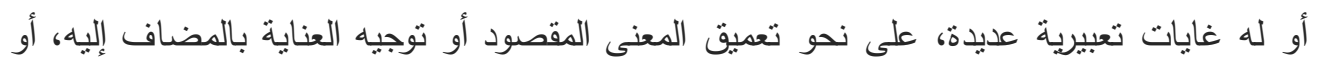

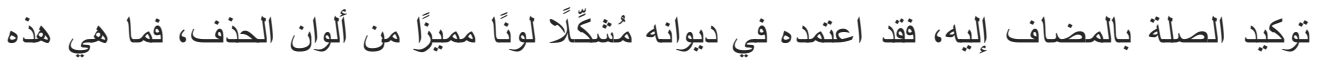
الفوائد، وكيف افاد منها الثاعر لإبراز النواحي الجمالية من هذا الحذف ؟ باعن

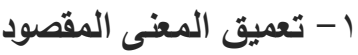

عدّ الثاعر أنّ المضاف قد يخفّف من التعبير عن حدّة انفعاله، لذا عمد إلى حذفه، ليعمّق المعنى الذي أراد تجسيده، يقول: "كيف أهرب منه ؟ أنه قدري/ وهل بملك النهر تغييرًا لمجراه" (ق. ماذا اقول لها) والنقدير : هل يملك مياه النهر تغييرًا لهجراه. حذف الثاعر المضاف (المياه) لفائدة تعميق المعنى، وكأنّ النهر يتجاوز حدوده ومجراه، ويفلت من هذه الحدود، ليسير على رسله كيفما شاء، لذاه يتساءل

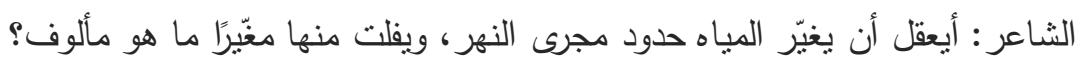


العدد الحادي والأربعون

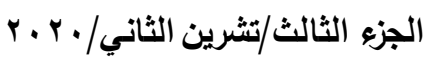

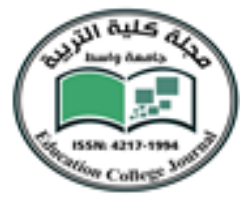

ويقول في مقام آخر : "إنّ الشعر / يجعل كلّ حلم ممكنًا/ وأنا أفكر باختبار الناي/ حتى بأكل الفقراء/

$$
\text { بعدي/ الميجنا"(ق. النقب). }
$$

النقدير: باختيار آلة الناي - فاكهة الميجنا. عدد الثاعر هنا إلى حذف مضافين اثثين (باختيار آلة

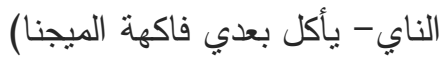
ولهذا الحذف فائدة بلاغية كبيرة، حيث أراد أن يعمّق المشهد، ويلفت النظر إلى شدّة إعجابه

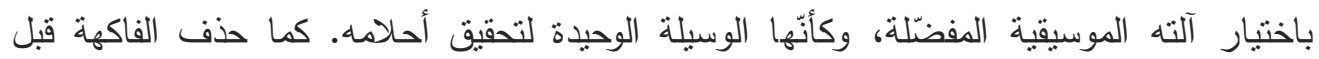

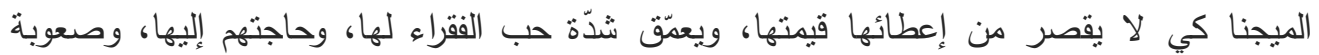
الحصول عليها، على اعنبار أنّها فاكهة الأغنباء بسبب ثنهها الباهظ.

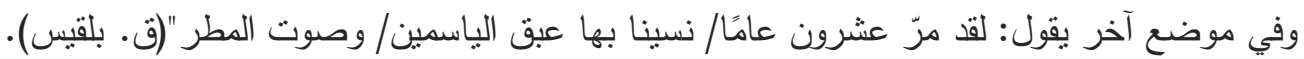
التقدير : صوت مياه المطر • وجّه الثاعر اهتمام السامع إلى المطر، وليس مياه المطر لتعميق مشهر

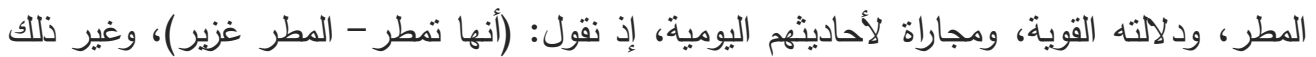
من صفات مياه المطر، ولا يقولون إنها تمطر مياه. يقولون مياه المطر تجرف كذا وكذا .. فالسامع يألف تكرار لفظة مطر، ويحذف المياه بحكم العادة، والسليقة، لذا تجري هذه اللفظة(المطر) على

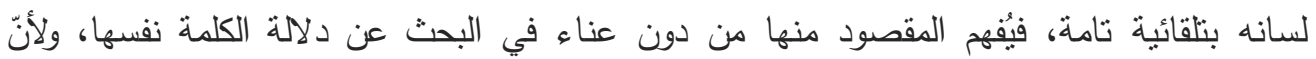
الثاعر أراد تعميق دلالة المطر، وفتحها على كلّ احتمالات كيفية هطول مياهه، حذف المضاف، لناه

$$
\text { وأعطى لما بعده قيمة مضافة. }
$$

ويقول في مقام آخر : "لا أدري كيف أقول الثعر / فحيث ذهبت يلاحقني الساطور "(ق. بلقيس).

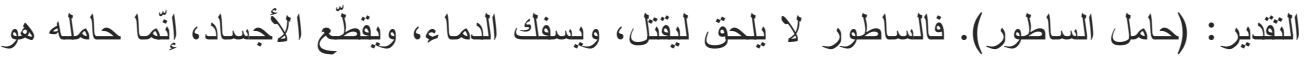

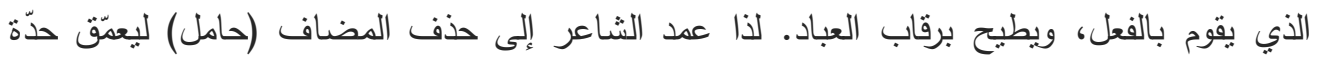

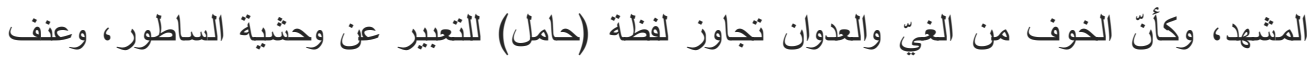
فعله جسديًا ومعنويًا.

\section{r - توجيه الغناية بالمضاف إليه}

قد يهيمن الدضاف إليه على فكر الثاعر، ويحتلّ موقعه في ذهنه، فيلجأ إلى تقنية حذف اليه المضاف ليوجّه العناية بالمضاف إليه، مع إبقاء دليل على هذا الحذف. وفي الديوان نماذج كثيرة

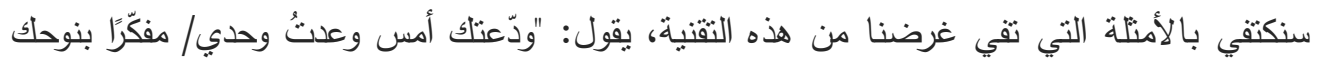
الأخير"(ق. إلى صديقة). 


\section{العدد الحادي والأربعون}

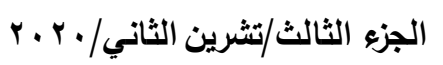

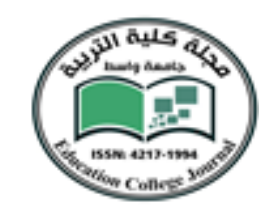

والثقدير : ودّعتلك (يوم) أمس. حذف الثاعر المضاف بفائدة إسراع المضاف إليه إلى ذهن المُتلقّي،

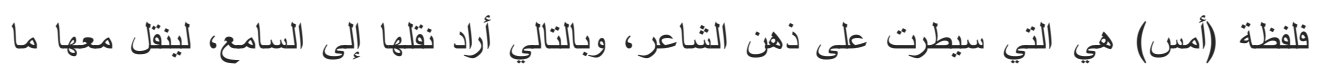

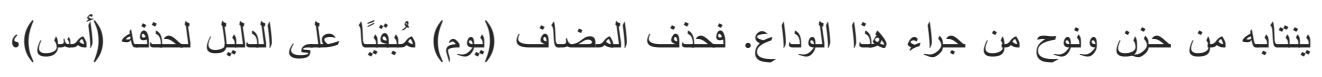
بهدف أن يحتلّ موقع المضاف إلبه في ذهنه.

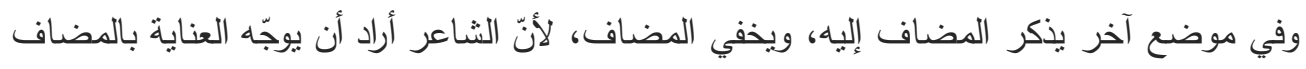
إليه لذا استعجل ذكره حاذفًا المضاف، يقول: "بلقيس: أيتها الأميرة/ ها أنت تحترقين في حرب العشيرة والعشيرة" (ق. بلقيس) التقدير : أهل العشيرة. عدد الثاعر إلى ذكر المضاف إليه (العشيرة) وحذف المضاف (أهل)، لأنّه أراد توجيه العناية إلى العثيرة كلّها، من دون استثناء أحد منها، فاستعجاله بذكر العشيرة جعله يحذف إنف

وفي موضع آخر، يجعل الثـاعر من حذف المضاف المتكرّر في مقطوعة واحدة يولي اهتمامًا خاصًا بالمضاف إليه، للكثف عن انحياز الصورة التي أرادها، وعدم تحقيق العدالة الاجتماعية، وعدالة السماء في آن، فوجّه العناية مباشرة إلى المضاف إليه، ليختصر المشهد الذي يريد التركيز عليه، يقول: "حين وزّع الله النساء على الرجال/ واعطاني إياك/ شعرت/ أنه انحاز بصورة مكثوفة إليّ/ وخالف كلّ الكتب السماوية التي ألّها/ فأعطاني النبيذ وأعطاهم الحنطة/ ألبسني الحربر/ وألبسهر القطن" (ق. .. - (1) رسالة). عمد الشاعر إلى حذف أربعة مضافات أعطاني (شراب) النبيذ، وأعطاهم (أكل) الحنطة، ألبسني (أثواب) الحرير ، وألبسهم (أثواب) القطن. هذا التوجيه بالعناية للمضاف إليه، جعل الثاعر في حالة نشوة، وانتصار، وفرح، وامتلاء رجولي، ورضى، كون الله ميّزه عن سائر أبناء جنسه، وخصّه بامرأة مباركة لا مثنل لها، لأنّ الهه أعطاه لها، أعطاه ومنّ عليه بالعطاء منحازًا إليه.

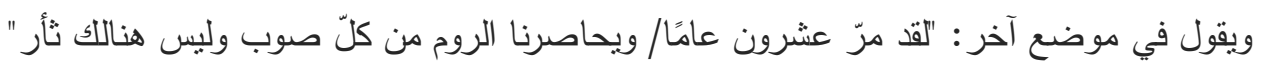
(ق. (النقب)

التقدير : جيش الروم. حذف الثاعر المضاف (جيش)، وليس الروم، ولكنّ الثاعر استعجل بذكر الروم، لأنّه المقصودون في حالة الحصار ، كونهم أعداعنا اللدودين، سواء أكانوا جيشًا أو مواطنين.

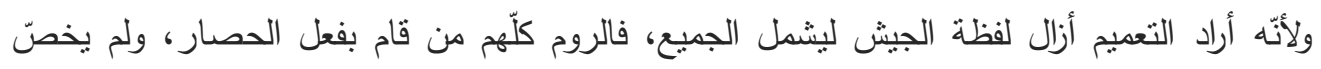
الجيش فقط، هذا ما جعله يعدد إلى حذف المضاف. 
العدد الحادي والأربعون

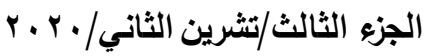

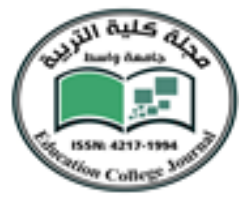

ب - لتوكيد الصلة المعنوية بالمضاف إليه:

إن ذكر المضاف أحيانًا يخفّف من الثُّحنة الثعورية التي يعيشها الثناعر ، ما يجعل ما بخفّة

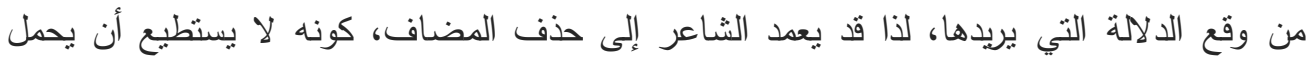
عمق انفعالاته، فيحاول إيجاد صيغ جديدة تفي بالغرض الذي بريد. ومن التراكيب المميزة في شعره نجد بعض النماذج الني أسقط منها المضاف، ليؤكّد العلاقة المعنوية بالمضاف إليه، ومن نلك يقول:

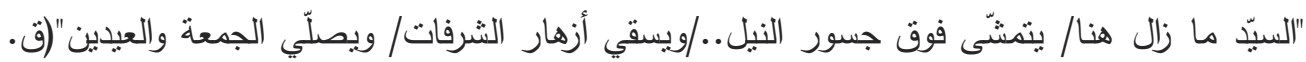

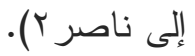
أي: يتمشّى فوق جسور (نهر) النيل، ويصلّي (أيام) الجمعة و (أيام) العيدين. حذف الثاعر المضاف

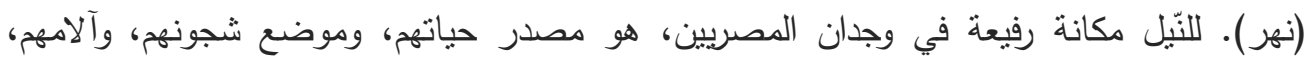

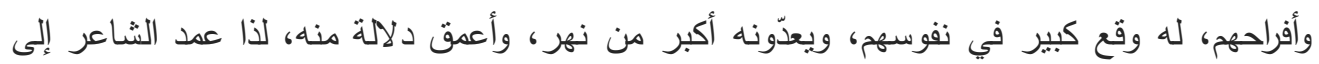
حذف المضاف (النهر) وأعطى المضاف إليه (النيل) قيمة كبيرة، حيث أولاه اهتمامًا خاصًًا وأكّد صلتهم أكثر به.

وكذا بالنسبة إلى المضاف (أيام ) فقد حذفه، لأنّه أراد عدم حصر الجمعة، أو العيد بيوم، أو أثثين،

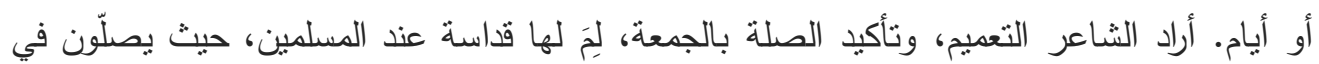

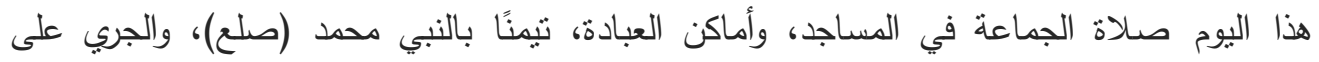

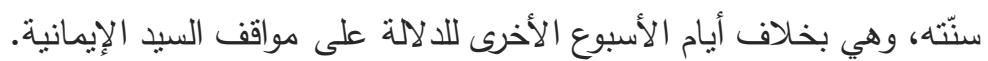

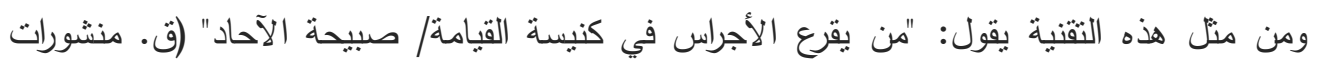
فدائية).

والمقصود صبيحة (أيام) الآحاد. عدد الثاعر إلى حذف المضاف(أيام) لتوكيد الصلة المعنوية

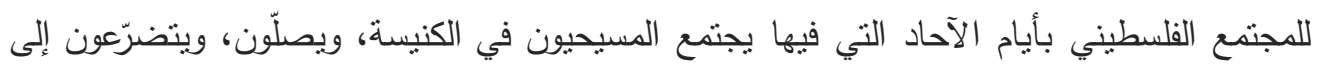

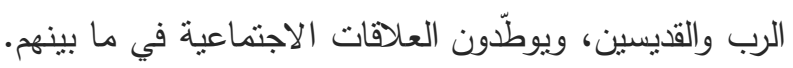

وفي موضع آخر يقول: "نساؤنا/ يرسمن أحزان فلسطين على دمع الشجر "(ق. منشورات فدائية)

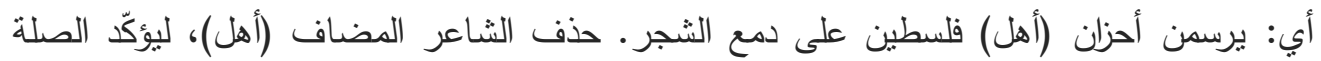

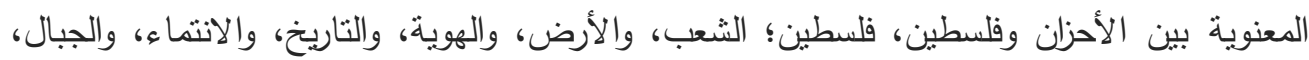

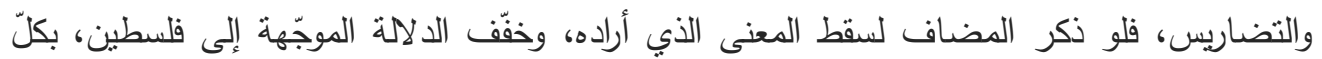
ما فيها، ومن عليها، مِن بشر وحجر وشجر وتاريخ وجغرافيا وذكريات وحضارات، وهذا ما لا يرده. 
العدد الحادي والأربعون

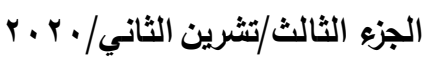
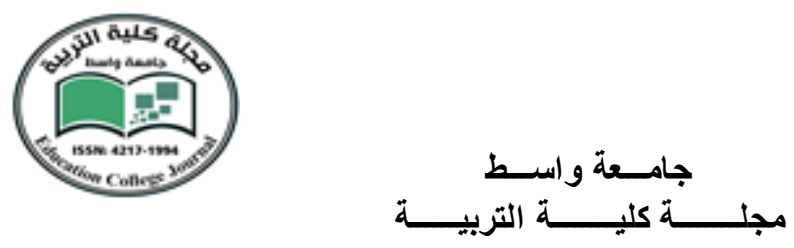

ع - الإيجاز

في واقع الحال أيّ حذف في أية تقنية يضاف إلى فائدتها فائدة الإيجاز ، وقد عرفنا أنّ حذف إنف المضاف من الثقنيات الثلاثة التي مرت أعلاه، فيها من الاختصار والاقتصاد في اللغة، ما يجعلها

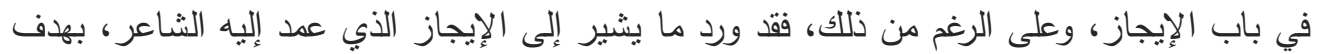

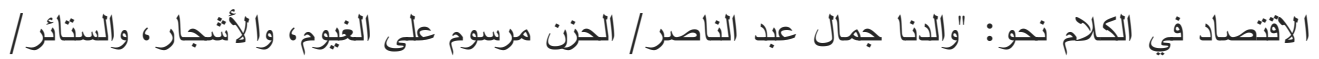

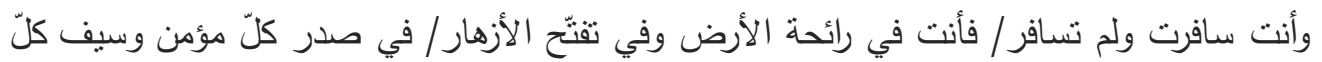

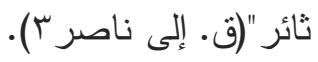

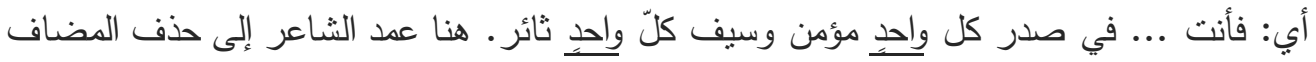
للإيجاز والاقتصاد في الكلام من باب التخفيف لذا حذف المضاف وظلّ على الصفة لأنّ استعماله على هذا النحو كثير. كما يعدد الثاعر إلى الإيجاز والحذف من باب التخفيف والكثرة الاستعمال يقول: " وفقتَّ يا وطني

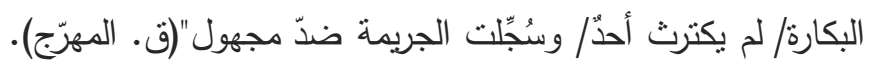

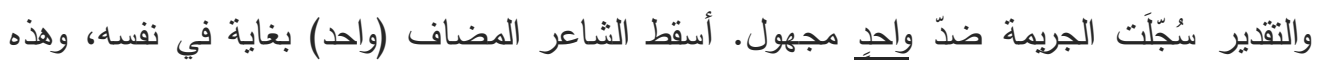
الغاية معروفة، فلا مبرّر للكره في السياق، وبذلك يقتصد في الكلام لكثرة استعماله أبضيًا.

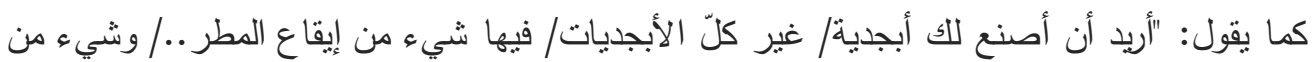

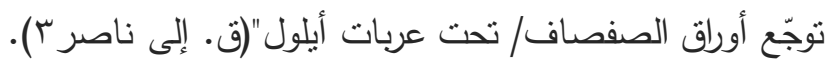
التقدير : إيقاع (مياه) المطر - تحت عربات (شهر) أيلول. عدد الثاعر إلى حذف الثرات المضاف (مياه)

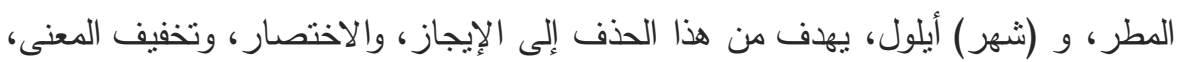

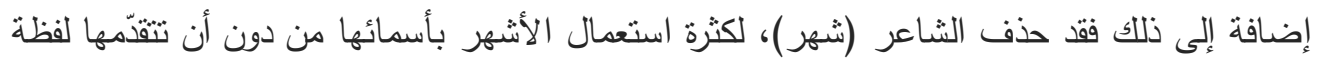

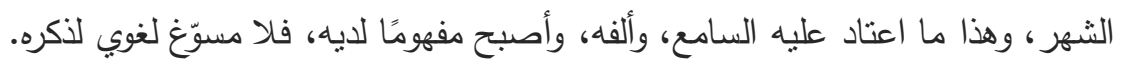
ثامناً - حذف المضاف إليه

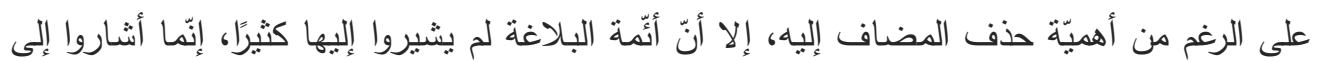
نماذج لهذه الثقنية، وذكروا بعض غاياتها. غير أنتّا قد نجد نماذج لحذف المضاف إليه في ديوان

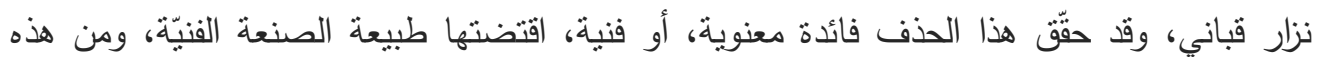


العدد الحادي والأربعون

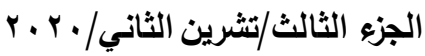
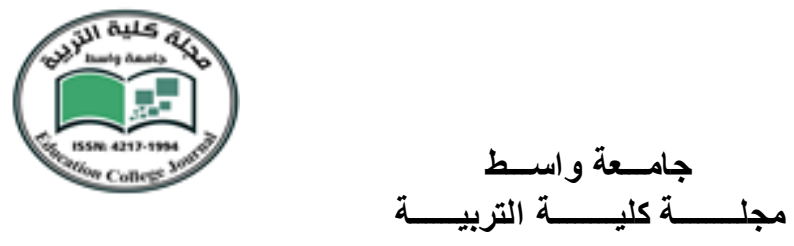

ا - اطلاق المعنى وتوسيع دلالته

عدد الثاعر إلى حذف المضاف إليه في مواضع بهذف إطلاق المعنى، وتوسيع دلالته من منل

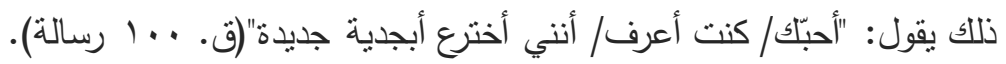

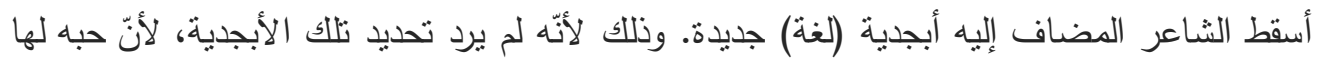
كبير، وهذا الحبّ حافز لإبداعه، وتفوّقه، وقدرته على مواجهة الصعاب. فلو أضاف على لفظة أبجدية شينًا لما تحقّت غايته في إطلاق المعنى، وتوسيع دلالتها.

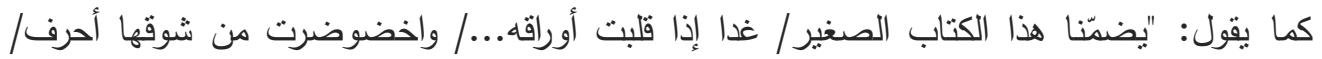

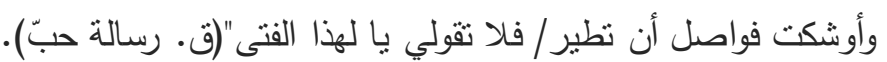

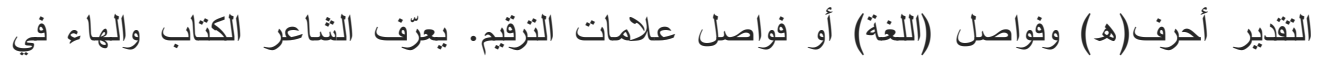

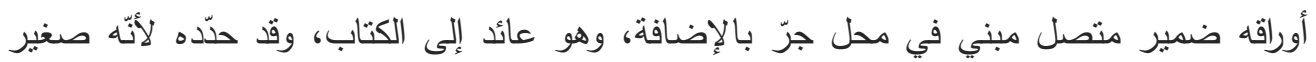

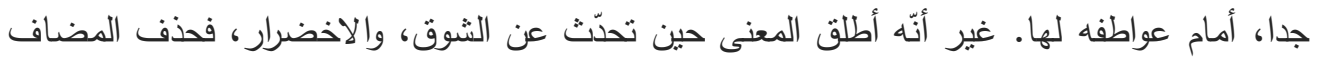

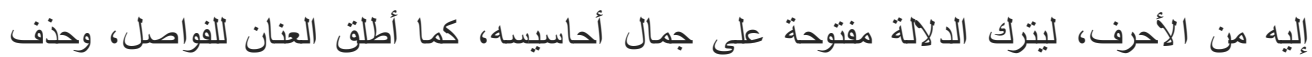
المضاف إليه، لأنّه لا يريد تحديد تلك الفواصل إلى الكتاب. r - للحفاظ على وحدة المشه الشعري

قد تحتاج وحدة المشهد الثعري إلى انتقاء الألفاظ، التي تساهم في بناء هذه الوحدة، وحفاظًا

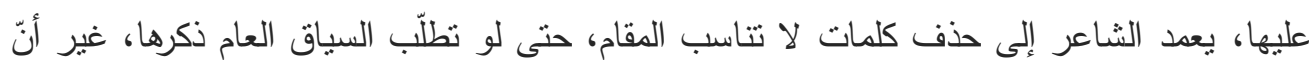

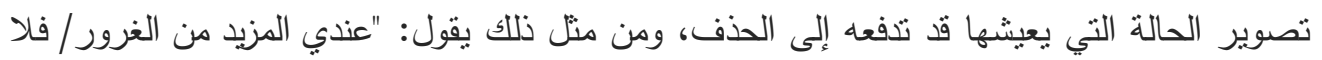

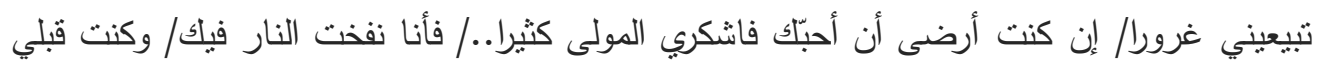
زمهريرا"(ق. إلى نهدين مغرورين). حذف الثاعر المضاف إليه الكاف في (غرورا)، لأنّ وحدة المشهر الثعري لا يسمح بذلك، حفاظًا

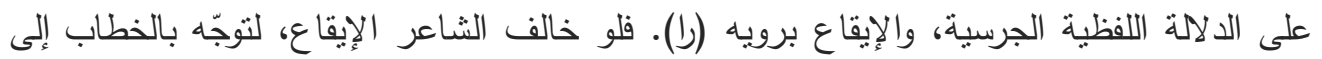
حبييته بضمير المخاطب المؤنث، وأحثث خلاًا في الموسيقى الثعرية، لذا بصحّ القول أن لا لا تبيعيني

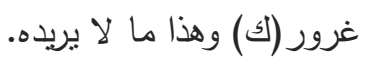
وفي مقام آخر يقول: "أسكتي يا شهرزاد/ أنت في واد وأحزاني بواد/ فالذي يبحث عن قصة حبّ// غير من يبحث عن موطنه تحت الرماد/أنت ما ضيعت يا سيدتي/ شيئا كثيرا/ وأنا ضيعتُ ناريخًا/ وأهلًا وبلاد "(ق م حوار مع امرأة). 
العدد الحادي والأربعون

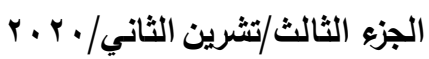

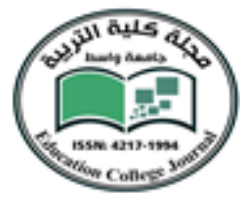

والثقدير أنا ضيّعتُ تاريخ(ي) وأهل(ي) وبلاد(ي). يعرّف الثاعر الأحزان بضمير المتكلم المفرد

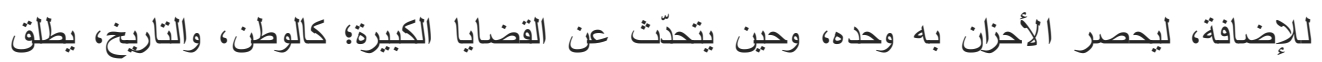

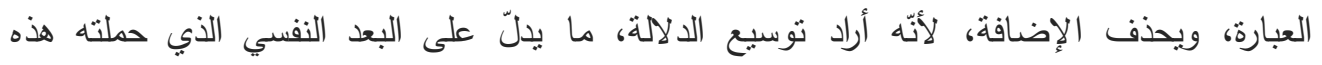

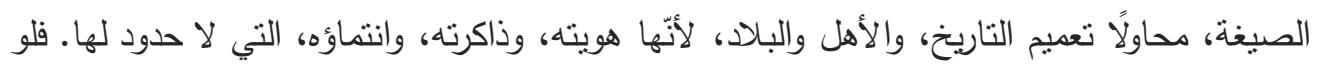

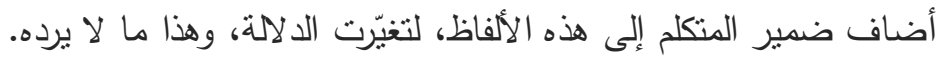

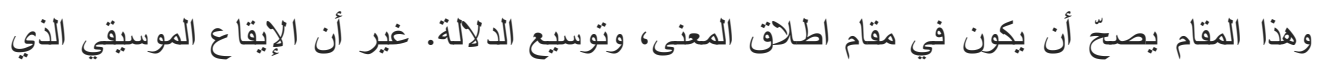

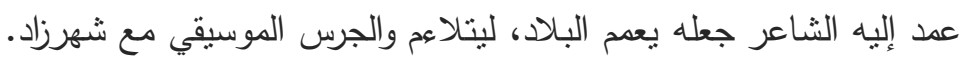
تاسعاً - حذف الموصوف

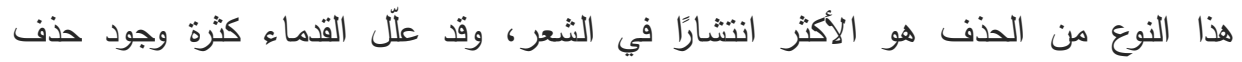

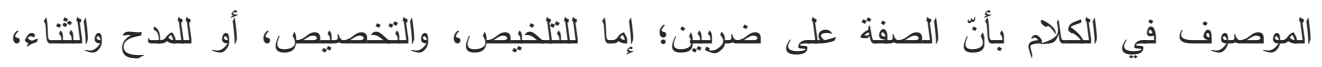

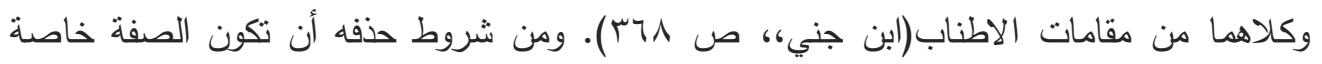

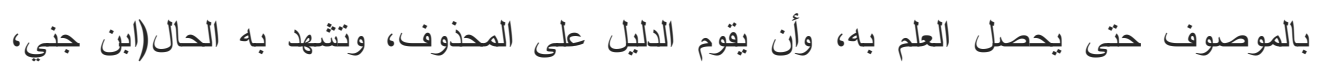

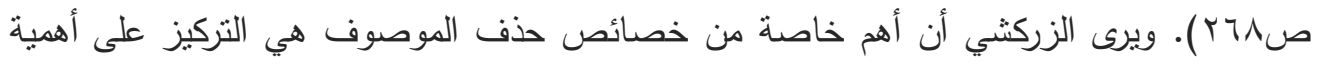

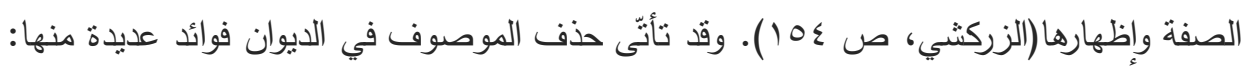

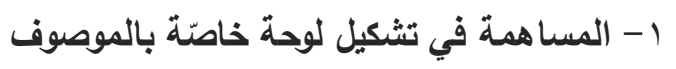
عد الثاعر إلى حذف الموصوف، في مواضع كثيرة من الديوان، وكانت الغاية منه الإبقاء على بلى باهي

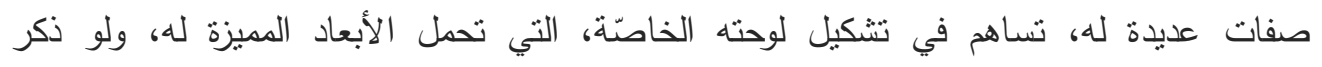

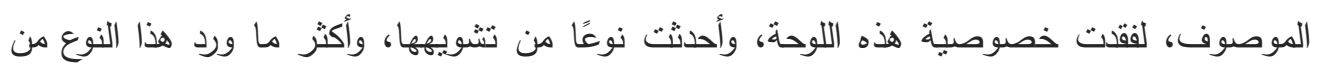

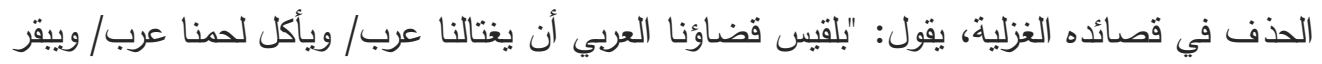
بطننا عرب/ ويفتح صدرنا عرب"(ق. بلقيس).

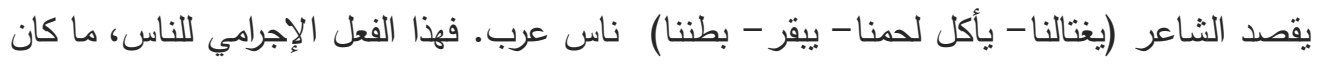
ليظهر بهذه الخصوصية، لو قال: ناس عرب، لأنّه أراد الشاعر أن يُحملّها مدلولًا خاصّا بها، وأبعادًا تميّزهم عن غيرهم. وفي مكان آخر ساهم حذف الموصوف في نشكيل صورة جميلة للصفة، يقول: "لكنّهم تركوا فلسطينًا/

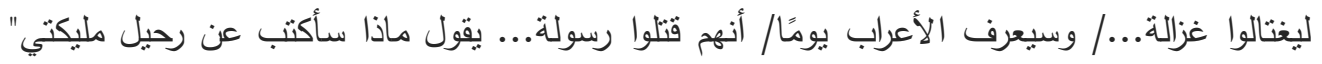


العدد الحادي والأربعون

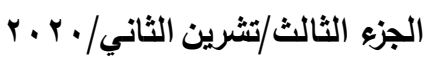

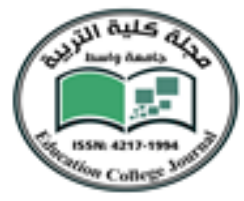

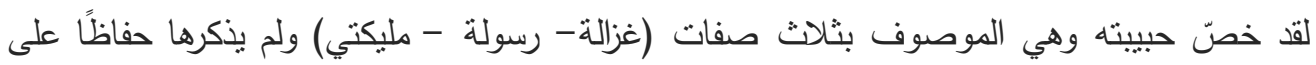
تشكيل لوحته الخاصة، التي تحمل الخصوصية، والأبعاد المميزة لها، فلو ذكر اسمها، لسقطت عنها هذه الخصوصية، وهذه الحالة القدسية التي أحاطها بها، وهذا ما لم برده.

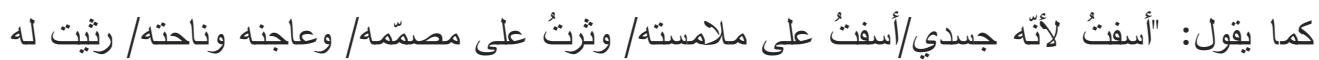

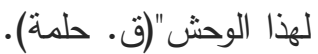
ذكر الثاعر الصفة الوحش وحذف الموصوف (الجسد)، لأنّه أراد أن يحبط الجسد بلوحة خاصة به، لوحة من الخوف، والثراسة والجموح، ولو ذكره لفقد الدلالة الدقصودة، إنّما بإسقاطه أحاطه بهذه الهُه

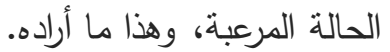
وفي موضع آخر يصف الحلمة، ويطلق عليها صفات كثيرة، لكنّه يحذف الموصوف (حلمة) ويُبقي على صفاتها، لتمجيدها، وتثديسها، والاستمتاع بها، ويرسم من خلالها جوًا من الحب، والفرح، واللهو، والنشوة، والاستئناس. ويضعها في مصافي الآلهة.

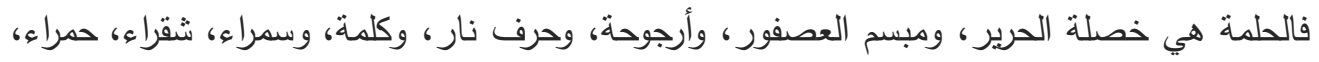
ودميعة، وقبلة، ومخيفة، ومظلة، وملمومة وفضية، وشباك.

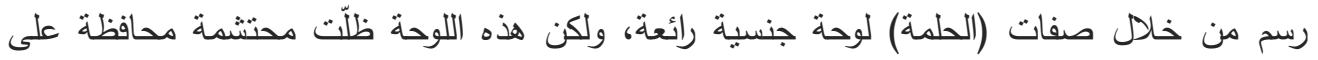
أناقتها، ولم نتزل إلى مستوى الابنذال والهبوط والثهوة الحسيّة، ولأنّها كل هذا الجمال، والكمال

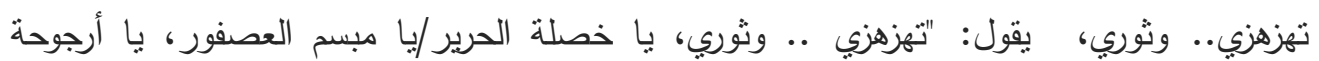

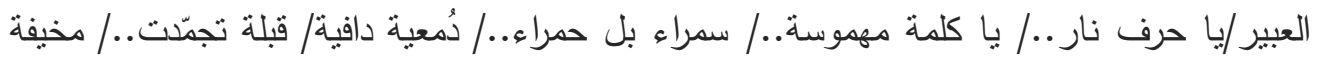

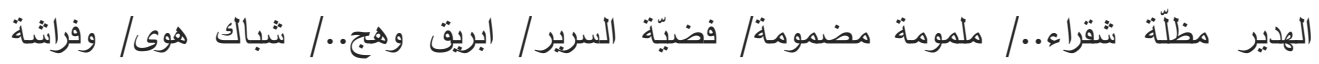

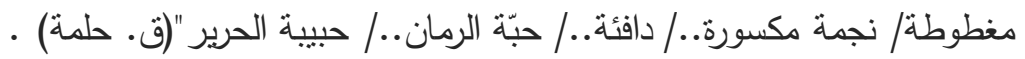
r- الإسراع بذكر الصفة

قد يلجأ الثاعر إلى هذا النوع من الحذف عندما ينتابه انفعالًا عاطفيًا، أو تأزمًا نفسيًا، فيقف الموصوف حاجزًا، يُؤَّر من إيراد الدلالة المطلوبة، بالسرعة المطلوبة، ويحدّ من سرعة التوصيل إلى لى

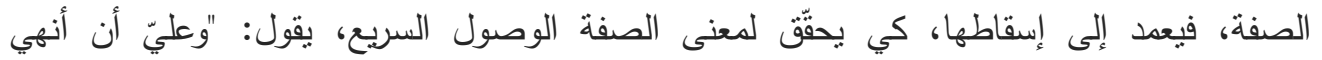

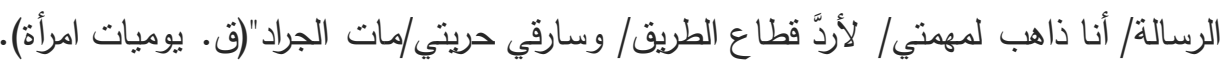

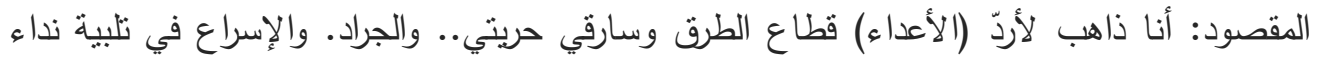

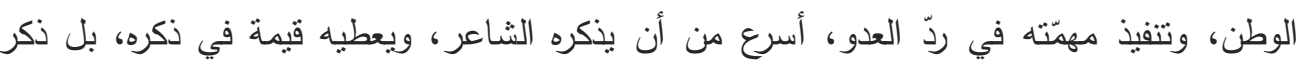

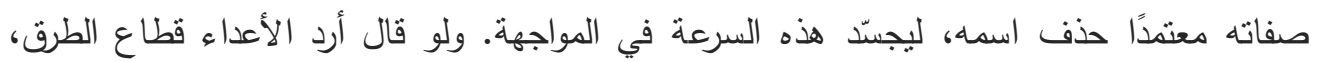


العدد الحادي والأربعون

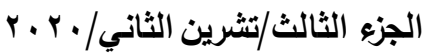

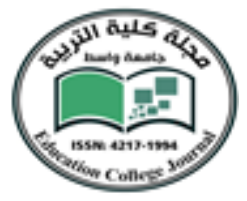

ومات الأعداء لأنّي قتت بواجبي الوطني، لما تحقّق الغرض من إيراد الصفات، ولما واعمت هذه الصيغة دلالة الفعل (أردّ- مات)

ومن منلها يقول: "ولا يسنظيع الحديث عن الحرب إلا المحارب"(ق. التعاريف).

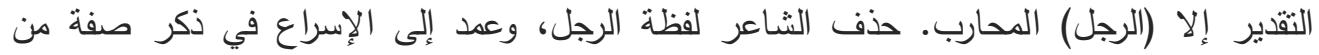

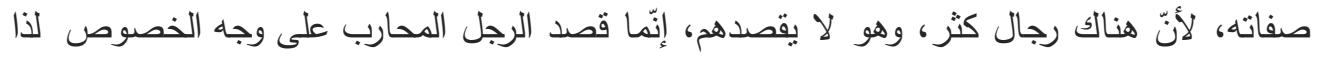

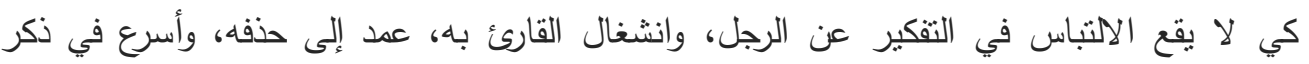
صفته لأنّه لو ذكره لساهم وجوده في تخفيف قيمته كمحارب، وهذا ما لا يريده. وفي مكان آخر يقول: "وأنا أفكر باختراع الناي/ حتى يأكل الفقراء"(قد فئه أدمنت أحزاني)

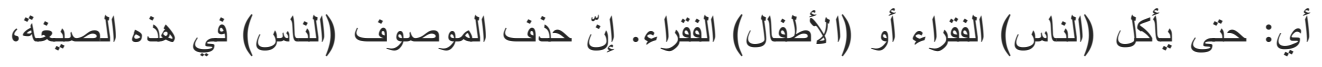

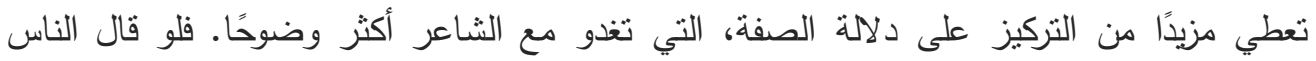

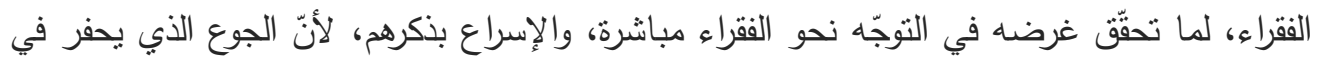

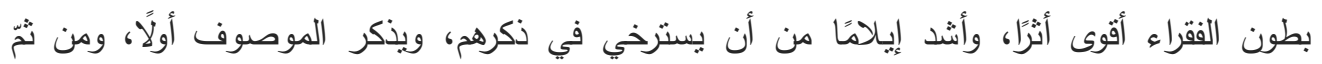

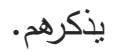

\section{ץ- حذف الموصوف للتركيز على صفة محدّة فيه}

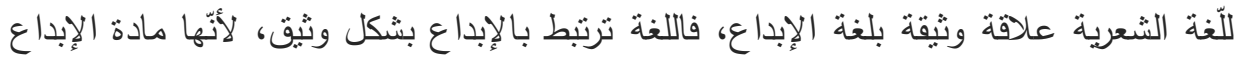

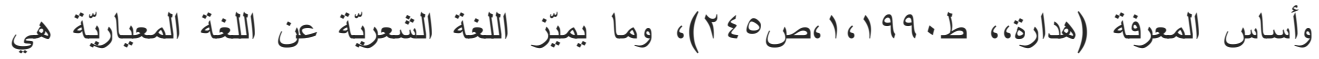

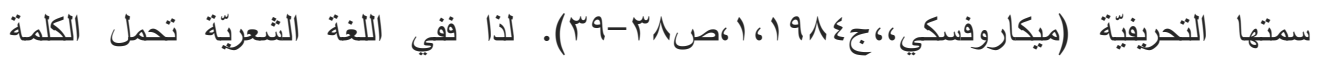

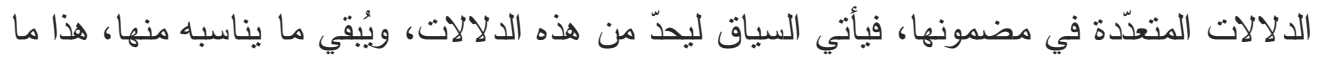

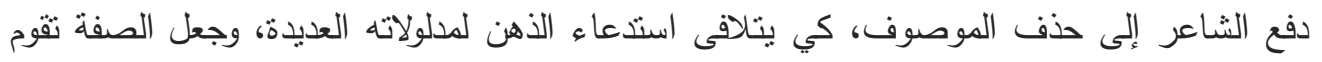

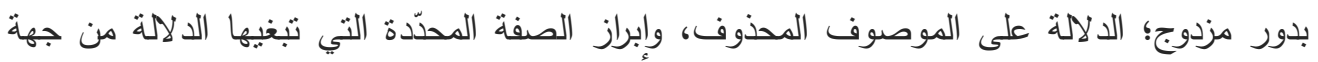
أخرى، يقول: "عندما قلتُ أحبّك/كنت أعرف أن المتوحشين سيتعقبونني/ كنت أعرف أن كلّ الأميين

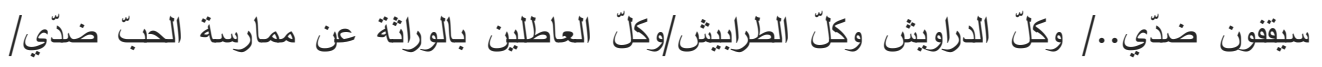

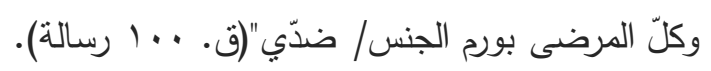

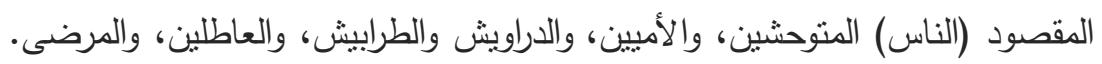

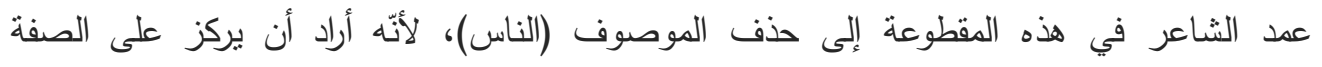

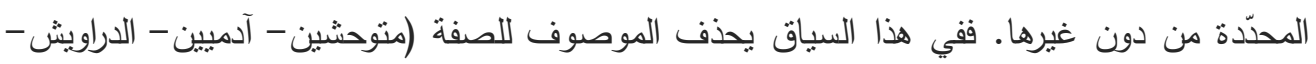

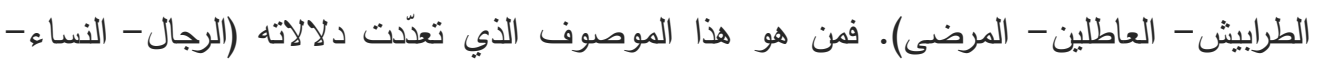


العدد الحادي والأربعون

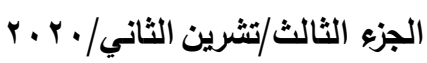

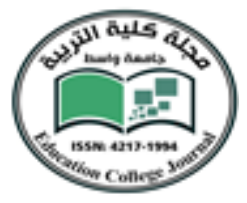

أطفال الشوارع- الأعداء- الخصوم ؟) لذا تلافيًا لاستخعاء الذهن لهذه المدلولات العديدة، اختصر

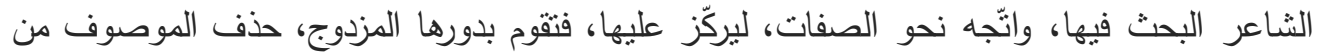
جهة، وإبراز صفة معيّنة فيه من جهة أخرى.

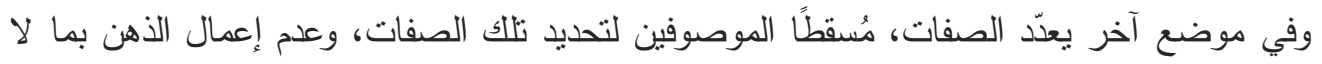

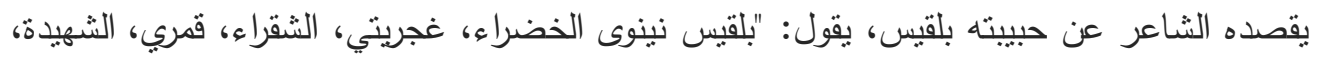

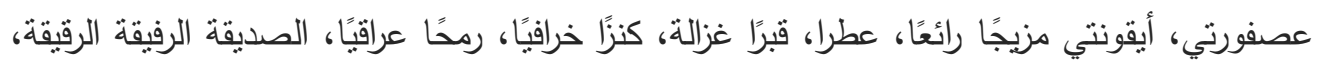

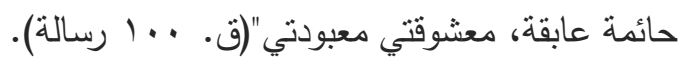

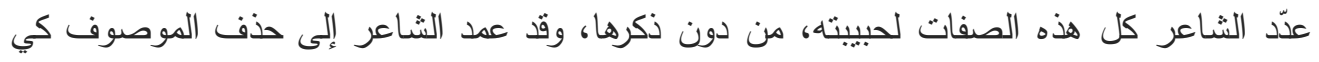

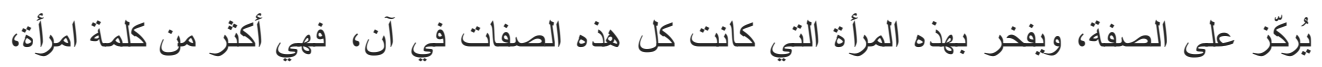
وأعمق وأعمّ.

ع - الإسراع بذكر الصفة واعمة

وقد يلجأ الثاعر إلى تقنية حذف الموصوف لفائدة الإسراع بذكر الصفة، نتيجة انفعالاته

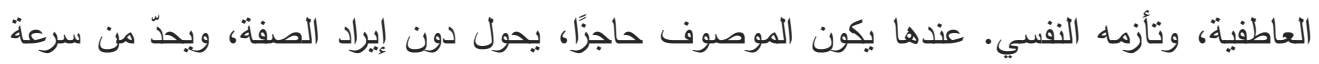

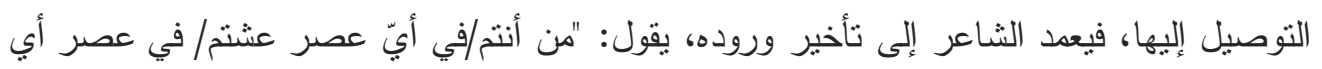
ملهم/ في عصر أيّ ساحر "(ق. إلى ناصر باع). التقدير في عصر أي (رجل) أو (حاكم) أو (رئيس). اختار الثاعر أسلوب الحذف ليجسد السرعة في إطلاق الصفة على الموصوف، فلو قال في عصر أي (رجل) ملهم أو (رجل) ساحر، لما تحقّق

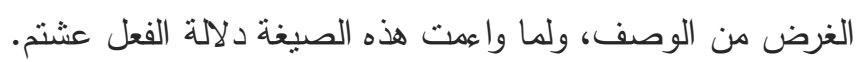
ومن منل نلك يقول: "محاصرون أنتم بالحقد والكراهية/ فمن هنا جيش أبو عبيدة/ ومن هنا هنا معاوية/

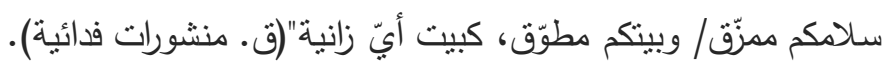

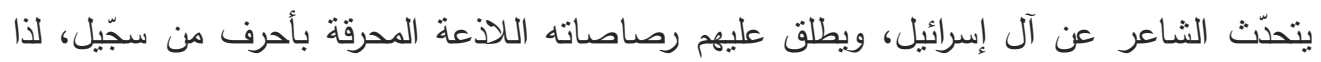
عمد إلى حذف الموصوف من العبارة الأخيرة (كبيت أي امرأة زانية) ليركز على الصفة وليحة ليحرة المهجو من بعض دلالات لفظة امرأة.

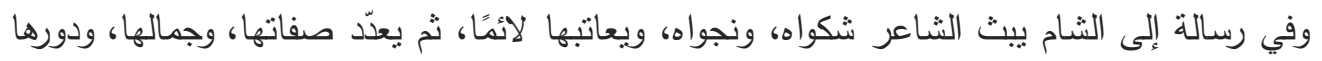

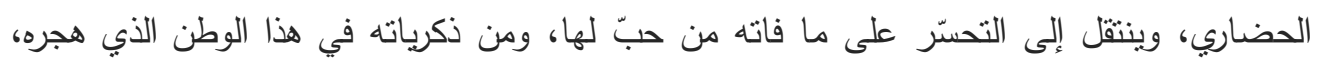

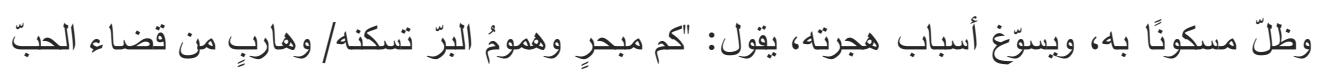
ما هربا"(ق. من مفكرة عاشق دمشقي). 
العدد الحادي والأربعون

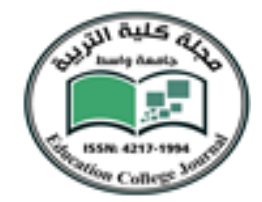

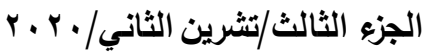

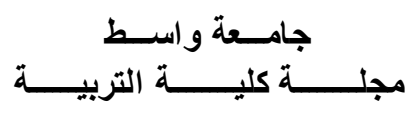

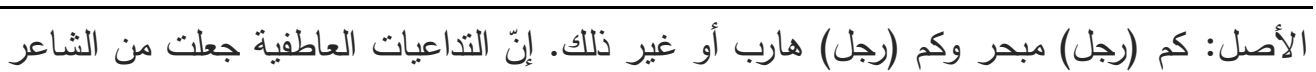

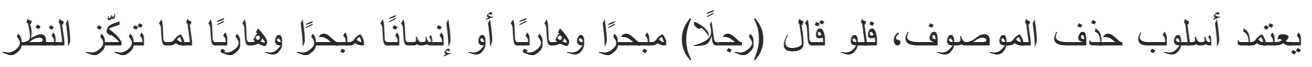
على هاتين الصفتين بالتحديد، ولما تحقّق القصصود ذاته، لكنّ أسلوب الحذف ساهم مساهمة قوية في تلك التداعيات العاطفية، والإسراع في إسقاط الموصوف للوصول إلى الغاية المرجوة. ولو عدنا إلى عنوان هذه القصيدة من مفكّرة عاشق دمشقيّ والأصل من مفكرة (رجل) عاشق دمشقيّ

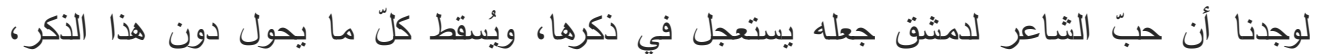
والصفة هي أقوى، وأهنن من لفظة رجل، أو إنسان، أو مواطن، فمها تعدّد الموصوف تبقى القيمة الكبرى القوية لذلك العاشق الدشقيّ. وفي موضع آخر يقول: "هذي دمشق وهذي الكأس والراح/ إني أحبّ وبعض الحبّ ذبّاح/ أنا الدمثقيّ لو شرّحتم جسدي/ لسال منه عناقيدٌ وتفاحُ"(ق. القصيدة الدمثقية).

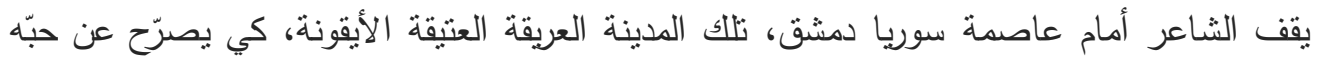

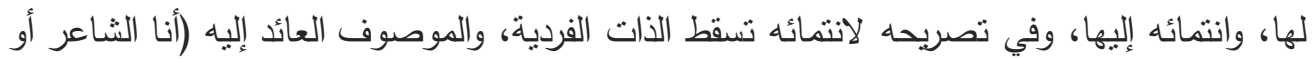
الرجل) ليسرع في ذكر الصفة التي تذوب الذات الفردية أمام عظمتها، ومجدها، وكينونتها، فيستخدم أسلوب الحذف، ليحقّق هذه الغاية السامية.

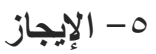
قد يعد الثاعر إلى حذف الموصوف من باب الإيجاز ، والاقتصاد في الكلام، والاختصار ، وذلك الكان

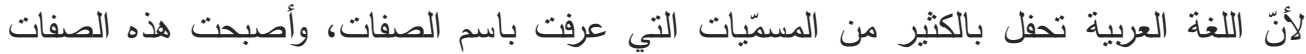

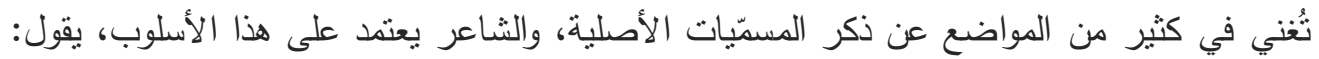
"أنيثُ يا شجرَ الصفصافِ مُعتذرًا فهل تسامحُ هيفاء ووضاح ؟"(ق. القصيدة الدمشقية).

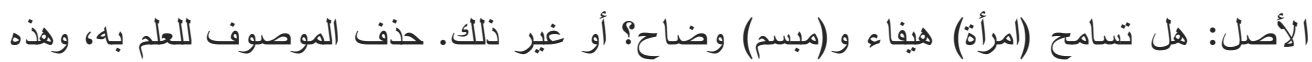
سنّة لغوية بعتمدها الكثيرون. ويقول في مقام آخر : "في بلادي/ حيثُ يحيا الناس من دون عيون/ حيث يبكي الساذجون/ ويصلّون ويزنون ويحيون انكال/ يا هلا/ أيها النبع الذي يمطر ماس/ وحشيثًا ونعاس"(قا. خبز وحشيش

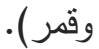
عدد الثاعر إلى حذف الموصوف من عبارة حيث ييكي (الناس) الساذجون/ ويمطر (ضوء) كالماس بهدف الإيجاز الاقتصاد في الكلام. 
العدد الحادي والأربعون

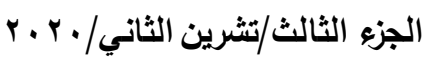

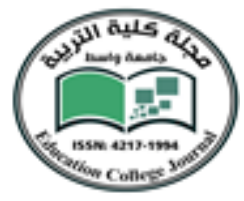

عاشراً - حذف الصفة

عرف القدماء هذا النوع من أساليب الحذف، ورأوا أن أكثر ما يرد في مقامات التعظيم، والتضخيم

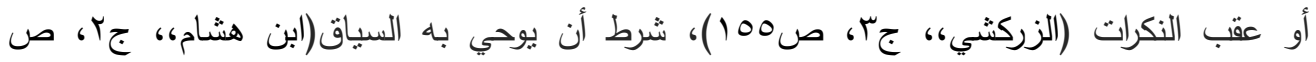

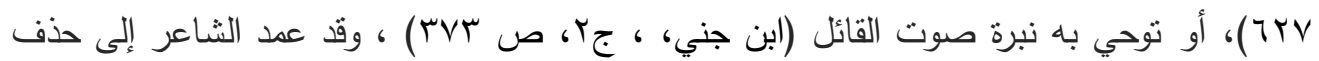

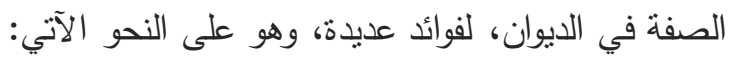

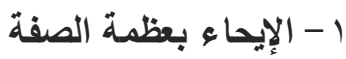

يلجأ الثاعر إلى حذف الصفة لأثّه يوحي بعظمة مكانتها وتفخيمها على نحو ذللك يقول: "بلقبس/ إن هم فجّروك فعندنا/ كلّ الجنائز تبنتي في كربلاء/ وتتنهي في كربلاء"(ق. بلقيس).

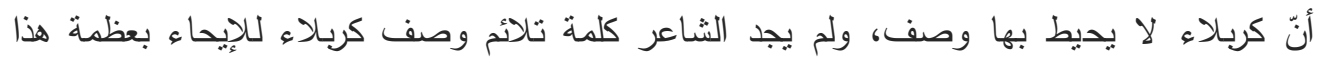
الحدث، لذا نجده ترك لفظة كربلاء مطلقة من دون وصف كي يجعل خيال السامع حرّا، فيتصور شدّة

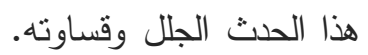

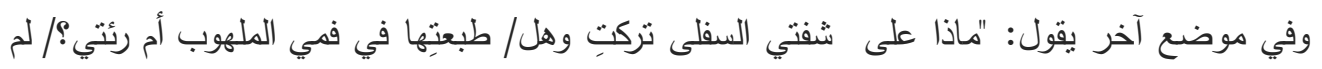
يبق لي منك إلا خيط رائحة/ يدعوك أن ترجعي للوكر سيدتي" (ق. القبلة الأولى)

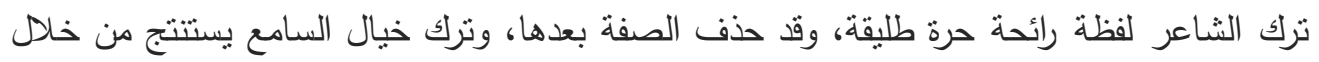

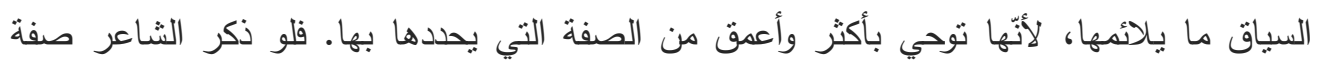

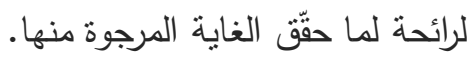
وفي مقام آخر يقول: "أخبر عني المنحنى والغدير/ واللوز والتوليب حتى أنا/ تسير بي الدنيا إذا ما

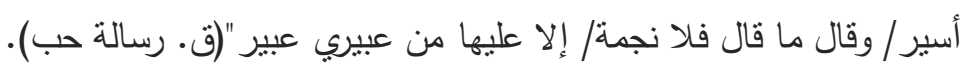

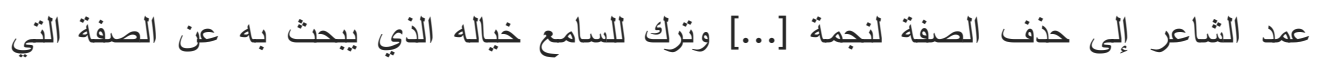
تلائمها، وتحيط بها وتجنّدها. كما يقول: "ادظلي في كنزة الصوف/ في جلدي وفي صونيا، صوني/ كلي من عشب صدري/ كحصان/

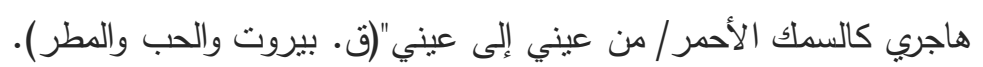

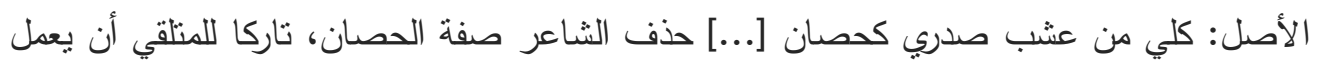

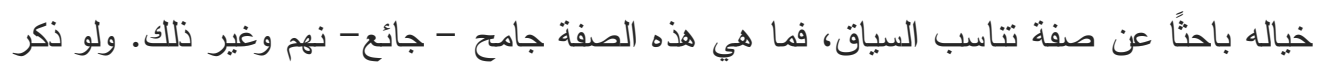

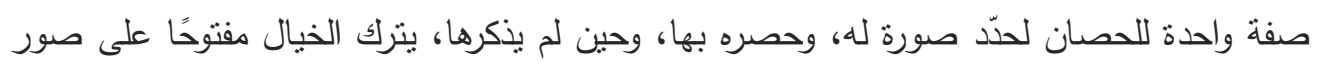

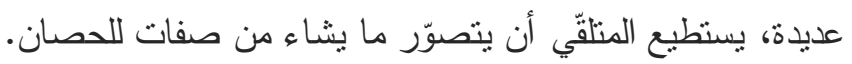




\section{العدد الحادي والأربعون

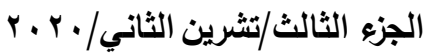

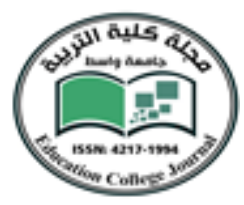

مثتع أن بصف الثاعر حبيبته فيطرح على جسدها، وكيانها كنوزا من الكلمات، ويقدمها هدية بين

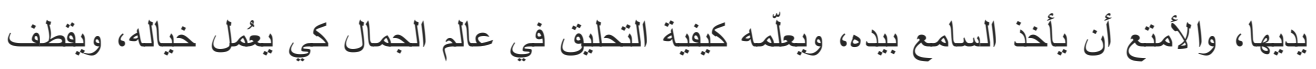

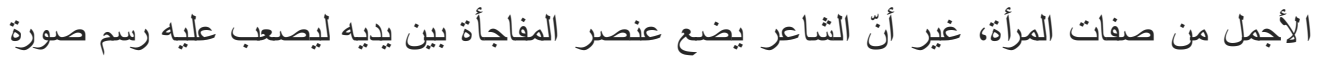
تخيلية لتلك المرأة، ويظل حائرًا عن تحديد تلك الصورة، ولكن من دون جدوى، يقول:

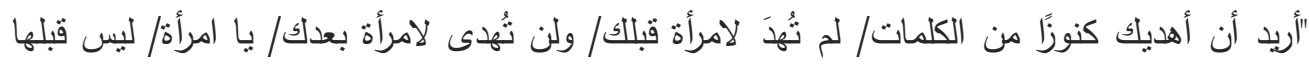

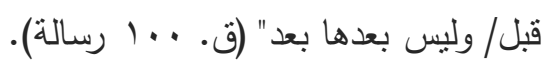
كيف للسامع أن يحدّد الصورة التي رسمها الثاعر لتلك المرأة، وما هي الهدية التي يقامها لها، كنوزًا

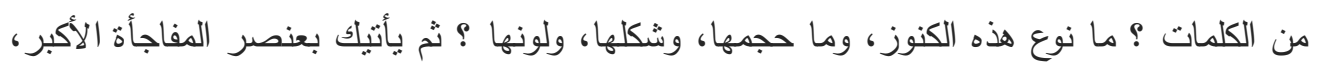

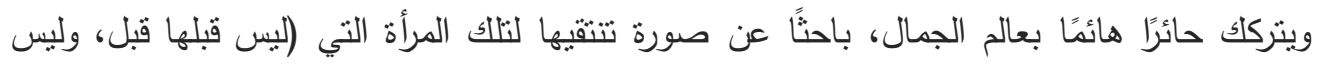

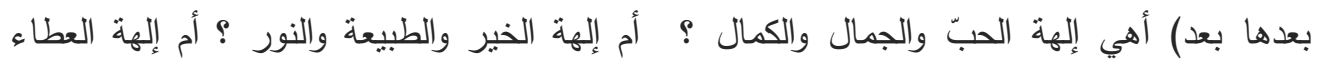

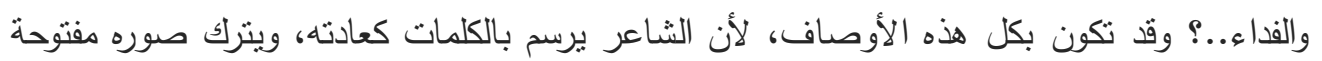

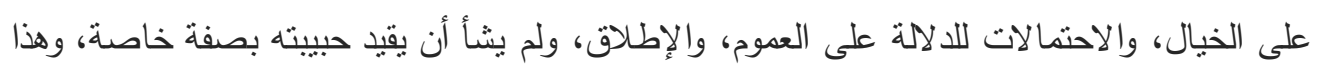
هو جماله، إنما ترك لنا ما يوحي بعظمة تلألك الصفة. r ب - تمكين الصفة من الموصوف

قد يحذف الثاعر الصفة لفائدة تككين معناها في ذات الموصوف، وعندما يحذف الصفة يستبدلها

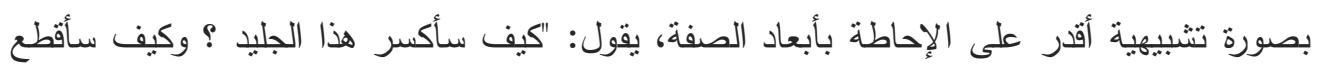

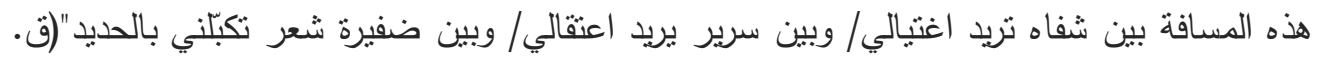

$$
\text { حب تحت الصفر ). }
$$

تحدّث الثاعر عن شفاه، وسرير ، وضفيرة، وكلّها موصوفات، غير أنّه عدد إلى حذف صفاتها ليمكّن

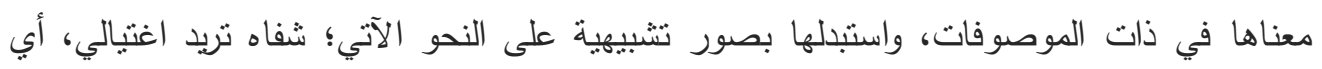

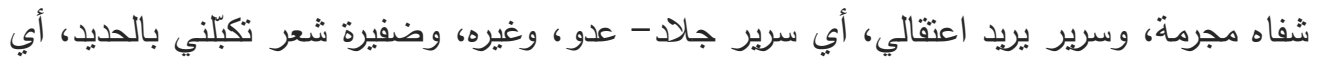

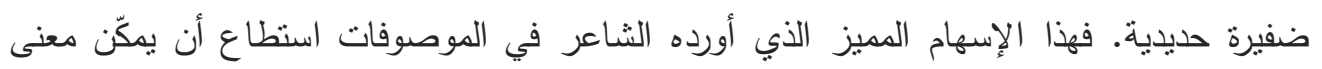

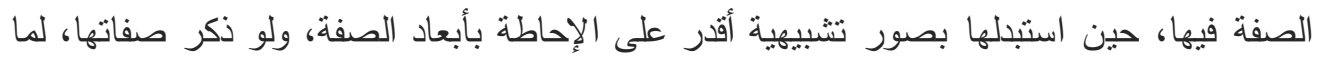
تحققت الغاية التي أرادها.

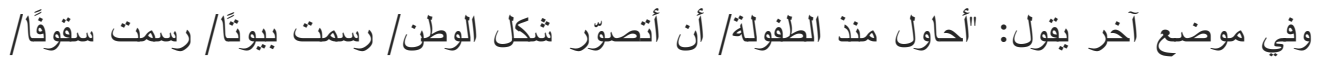

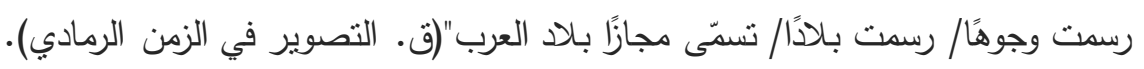


العدد الحادي والأربعون

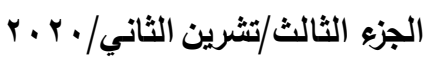

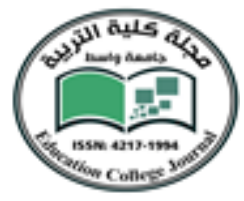

ذكر الثاعر بيونًا، وسقوفًا، ووجوهًا، وبلادًا، من دون تحديد الصفات لها، لكنّه حدّدها برسم صور تشبيهية فيها، كيف يتصوّر الطفل شكل الوطن، والبيت، والسقف، والوجه، والبلاد، وحين سمّاها مجازًا

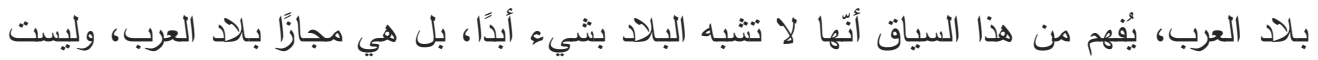

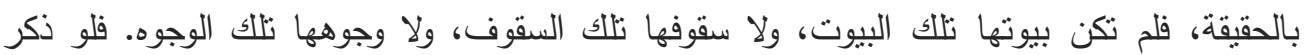
صفات لهذه الموصوفات لخفّف من قوّة المعنى المراد وكثافته.

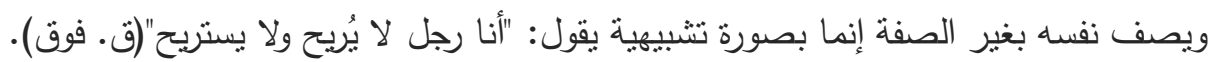

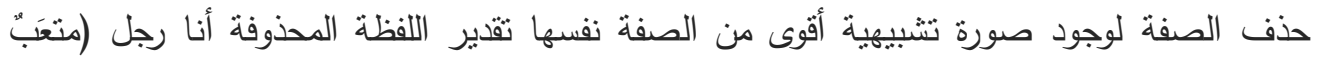
ومتعِبٌ) لا يُريح، ولا يستريح. وفي مقام آخر يقول: "هل عندك شكّة/ أنك أحلى امرأة في الدنيا وأهم امرأة في الدنيا../ يا امرأة تكسر حين تمرّ جدار الصوت"(ق. هل عندلك شكّة).

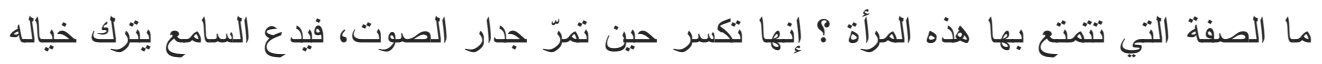

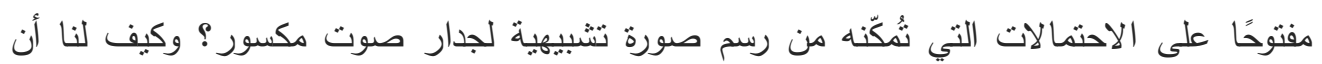

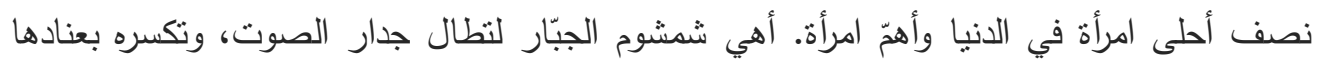

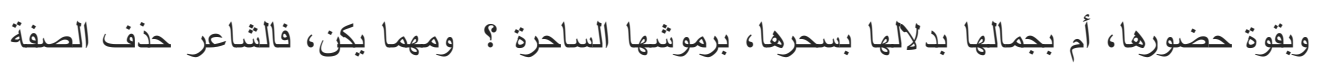

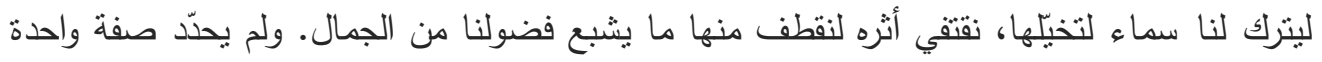
واضحة لتلك المرأة عن قصد منه لنشاركه تخيّل الدالالات التي يريد.

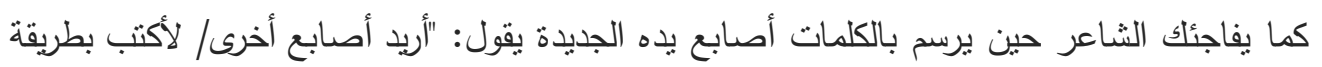

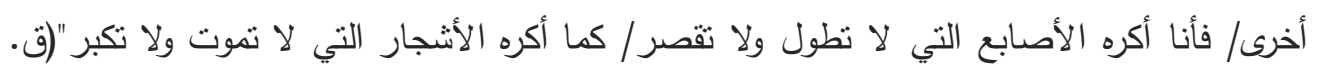

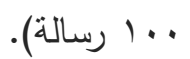
فما شكل الأصابع التي أرادها الثاعر وما حجمها أو لونها..؟ أسئلة كثيرة تجعلك تجوب في فضاء

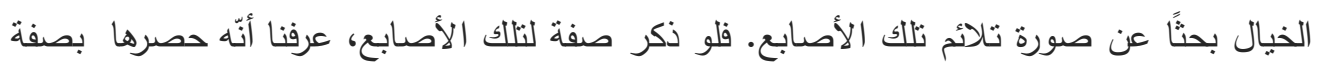

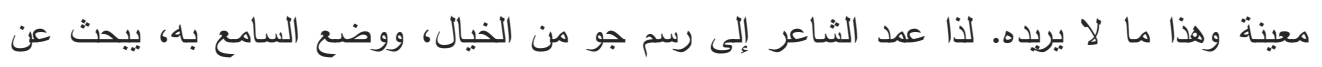

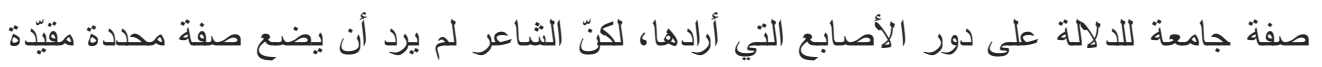

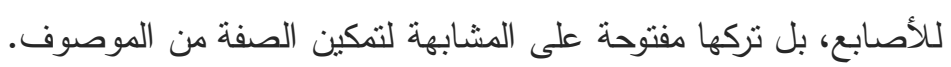


العدد الحادي والأربعون

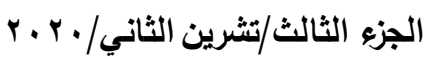

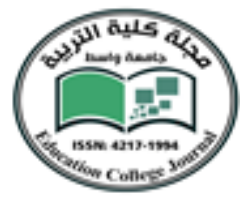

$$
\text { r- (الإيجاز }
$$

حذف الثاعر الصفة في بعض الأماكن اقتصادًا في الكلام، وإيجازًا، له ليعطي قوله صفة

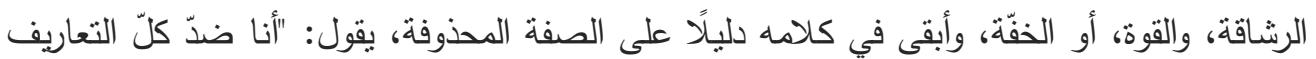

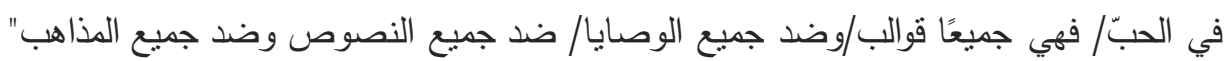

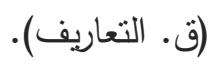

بعدّ الثاعر كل تعاريف الحب قوالب، لكنّه عدد على إسقاط صفة للقوالب لنظلّ جامعة لصفات

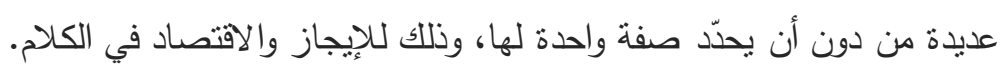

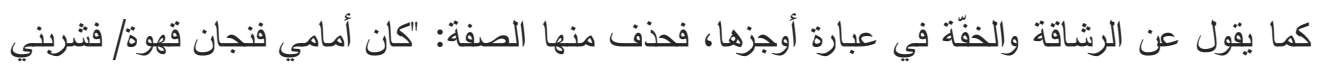

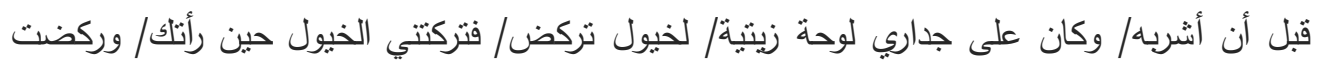

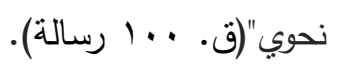

يذكر الثاعر (فنجان قهوة) و (خيول) من دون صفة. كان باسنطاعة الثاعر وضع صفة لللموصوف (فنجان) و (خيول)، لكنّه حذف الصفة متعدّا لهذا الحذف، لذا اقتصد في الكلام، ولم يرد

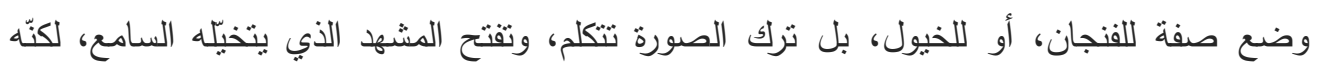

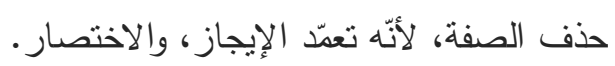

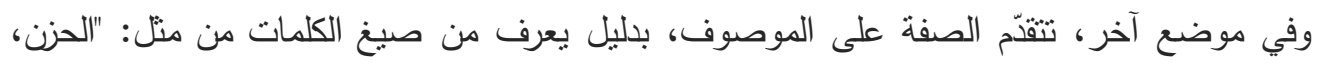

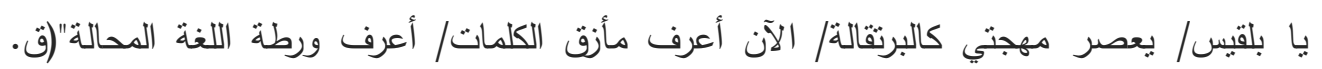
بلقيس). ذكر الثاعر المهجة ولم يذكر صفة تلائمها. فقد حذف الصفة للموصوف (مهجتي) وذللك لوجود دليل

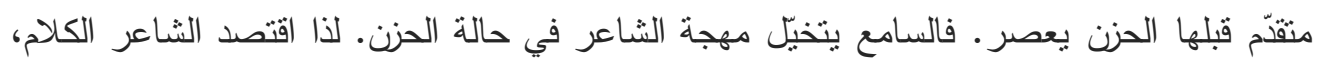

$$
\text { حادي عشف الصفة. }
$$

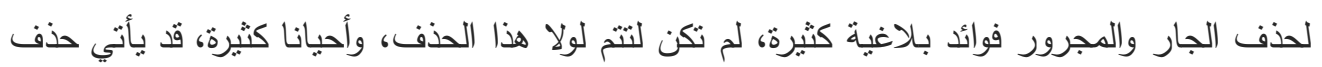

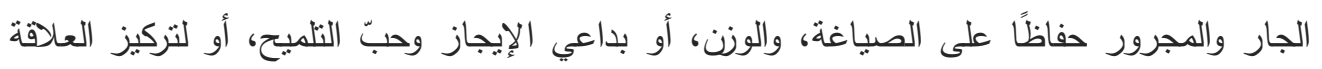

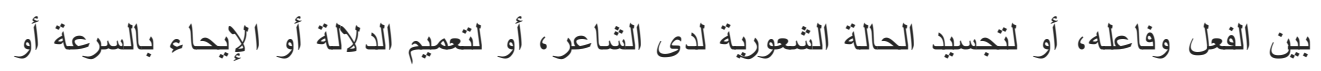

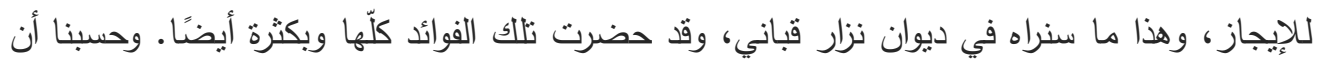

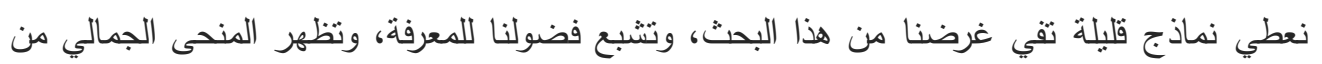

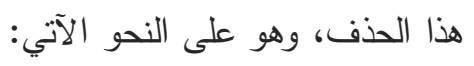


العدد الحادي والأربعون

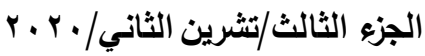

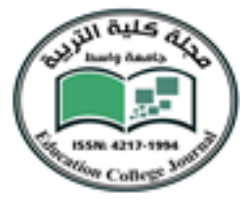

1- التركيز على العلاقة بين الفعل والفاعل

لتنكين العلاقة بين الفعل وفاعله، وتركيزها، عدد الثاعر في كثبر من الأحيان إلى تنليط

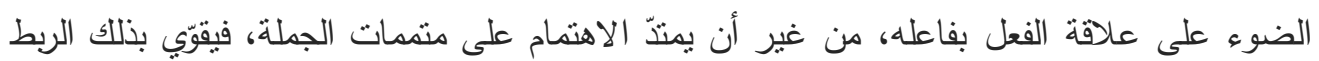

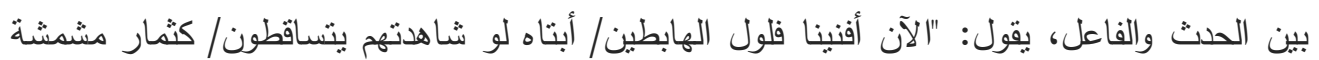
عجوز" (ق. رسالة جندي).

أي الهابطين (إلينا- علينا) ويتساقطون (على الأرض). حذف الثاعر الجار والمجرور (إلينا - علينا

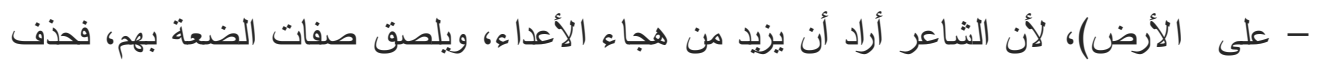

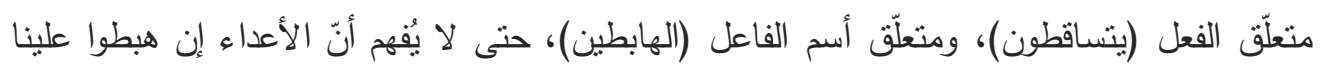
أو تساقطوا على أرضنا، قد لا يهبطون، ويتساقطون على أرض الآخرين.

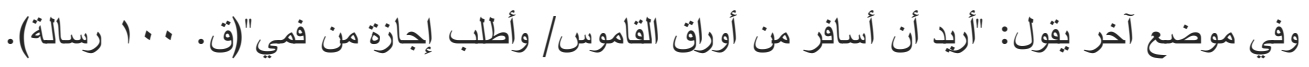

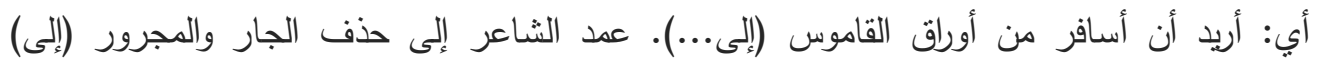

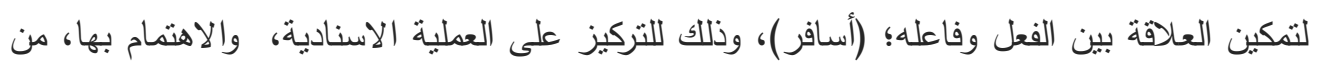

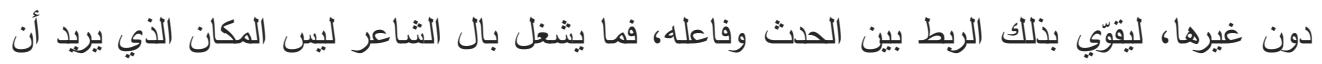

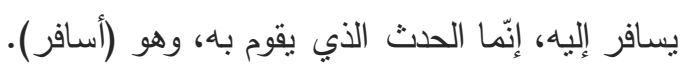

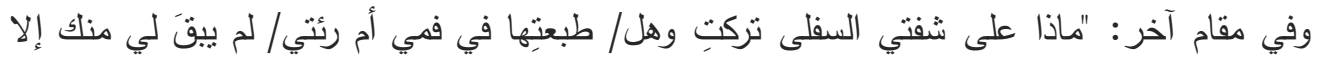

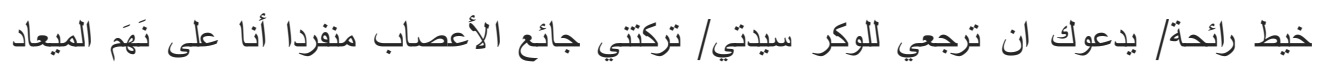
فالتفتي" (ق. القبلة الأولى). التقدير: تركتني (في مكان..) فالتقتي (إليّ). عدد الثاعر إلى حذف أكثر من جار ومجرور في هذه

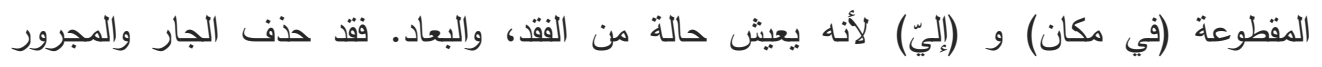

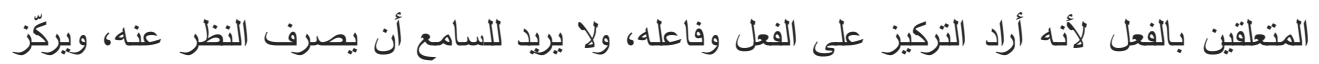

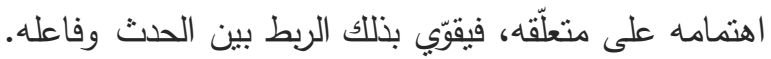

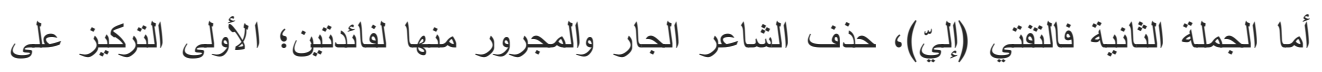

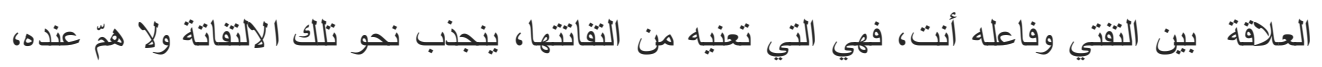

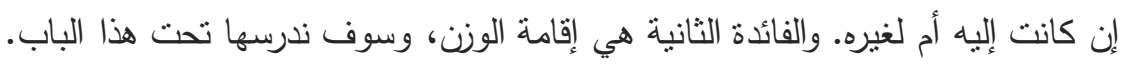
ب - ب ت تجسيد الحالة الثعورة يساهم حذف الجار والمجرور في تجسيد حالة الثاعر الانفعالية، والنفسية، والثعورية، وقد لجأ إليه الثاعر في الكثير من الأحيان. 
العدد الحادي والأربعون

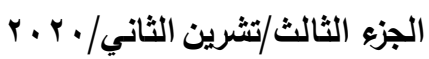

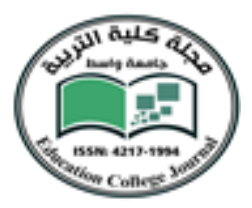

وها هو يحذّر الأعداء، ويتوعدهم مهدِدًا بنبرة حماسية حاسمة، يقول لهم: "لن تستريحوا معنا/ كل قتيل

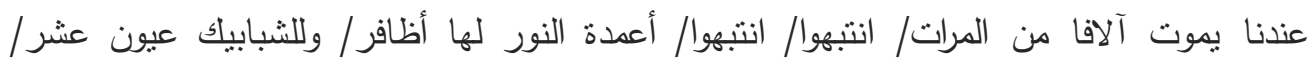

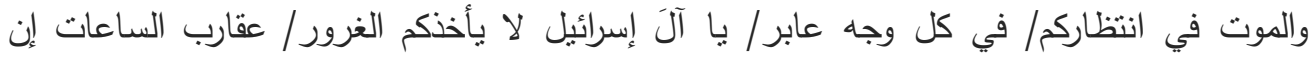
توقفت/ لا بدّ أن ندور" (ق. منشورات فـائية).

أي: انتبهوا منا- من بطشنا- من ثُورتنا/ من مواجهتا... عقارب الساعات إن توققت (عن العمل). إن لن انفعالات الثاعر العاطفية جعلته يجسّ حالة من التهديد، والتحذير، فحذف الجار والدجرور للالالة

على الحالة النفسية التي يعيشها.

وحين يرثو الثاعر حبيبته بلقيس، يعيش حالة من الانفعالات الثعورية فيصفها، ويذكر أثرها الطيب والجميل في نفسه، كونها حبية قلبه، وصديقة الجمال، ورفيقة الرشاقة، ونظلة ضاربة عمقًا في أرض العراق ، وفي هذا الوصف يكثف عن أبعاد حالته النفسية، فيعد إلى حذف الجار النهار

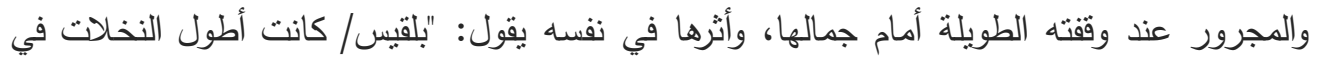

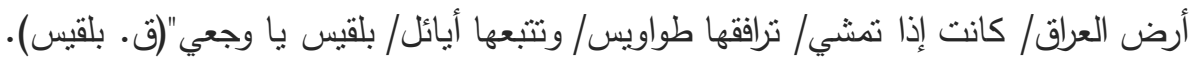
المقصود: كانت إذا تمشي (في أرض العراق) أو في أي مكان ترافقها طواويس (إلى أي مكان أنسان)

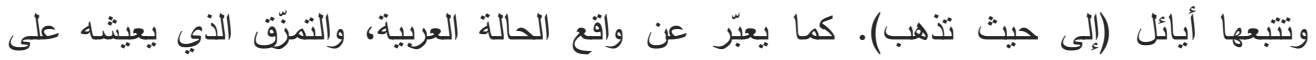

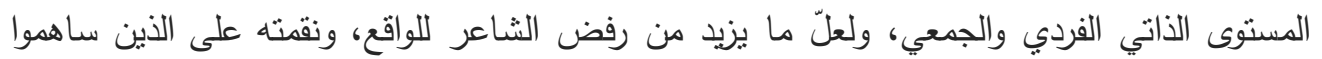

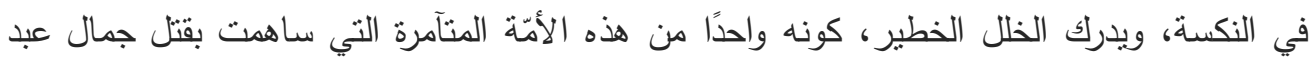

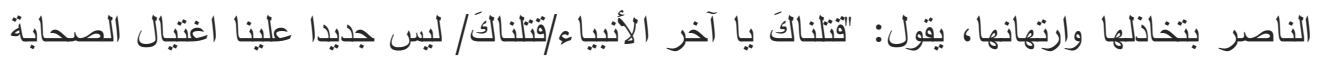

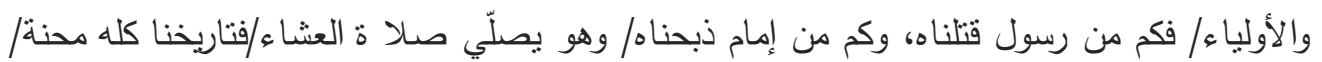

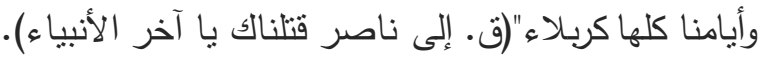

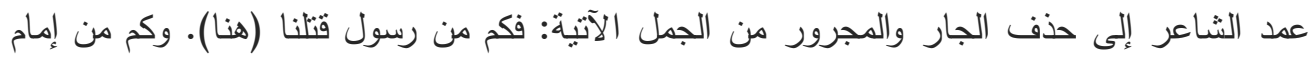
ذبحناه (في الوطن). فتاريخنا كله محن (في الوطن) ومن الواضح أن الثاعر حذف الجار والمجرور لأنه يبدو في حالة نفسية متأزمة، نتيجة الوضع الذئي تعيشه الأمة العربية، في وطن مزّقته الأحقاد والمؤامرة والخيانة.

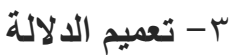

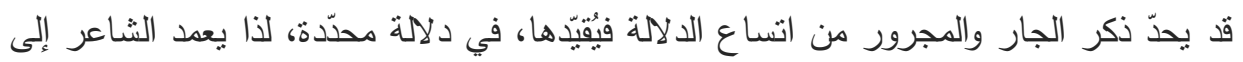
حذفهما لإزالة القيد عندما ينطلب السباق ذلك يقول: "عندما تمطر في بيروت/ تتمو لكآبتي غصون/ 


\section{العدد الحادي والأربعون

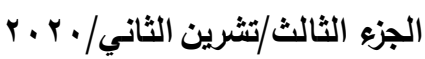

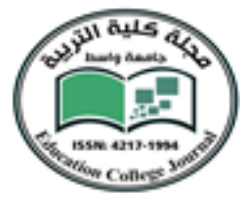

ولأحزاني بدان/ فادظلي في كنزة الصوف ونامي/ هذه كلّ الدفاتيح/ فقودي أنت/ سيري باتجاه الريح

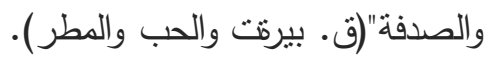

عدد الثاعر إلى حذف الجار والمجرور المتعلقين بالأفعال؛ تنمو ( في ..) ونامي (على...) قودي

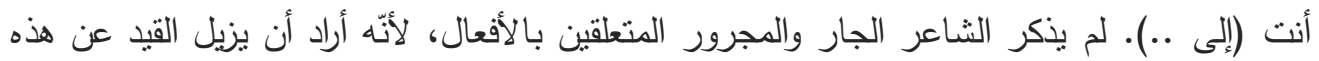

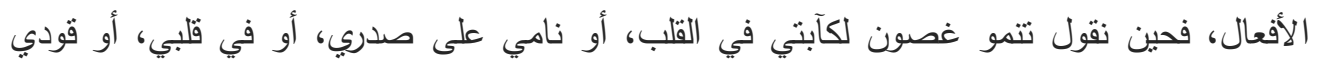

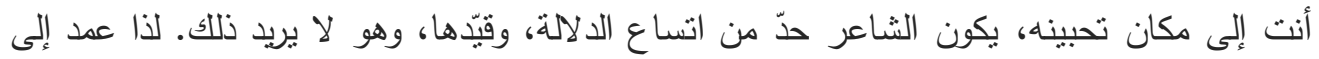

$$
\text { حذف الجار والمجرور المتعقين بالأفعال (تتمو - نامي - قودي). }
$$

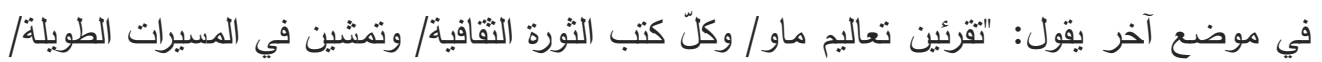

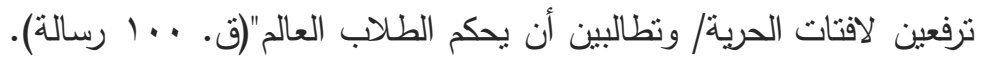

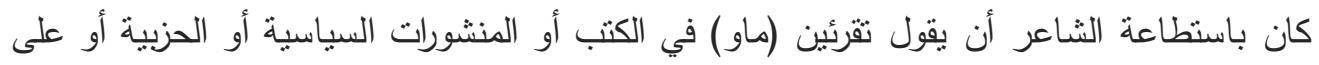

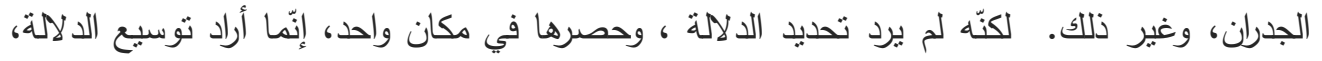
وعدم تقيبدها، لذا حذف الجار والمجرور المتعلقين بالقراءة لإزالة هذا القيد.

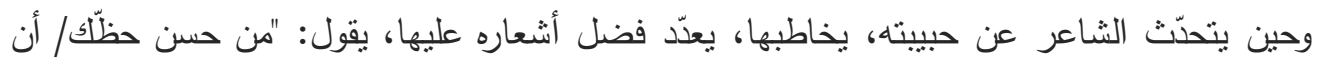

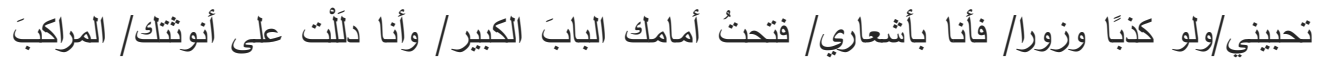
والطيورا/وجعلت منك مليكةً، ومنحتلك التاج المرصّع/والسريرا"(ق. بإنى إلى نهاين مغرورين).

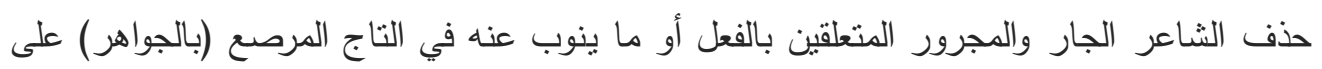

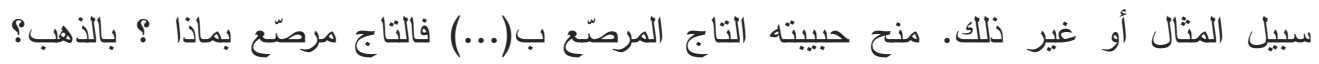

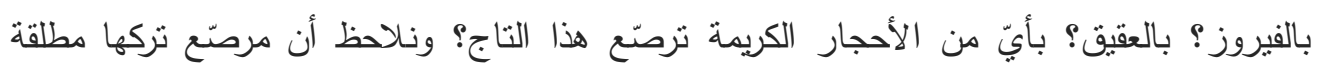

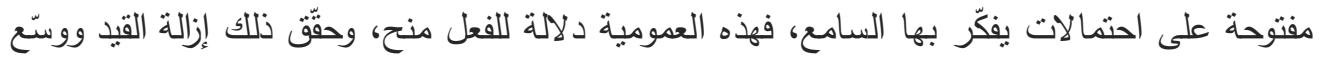

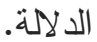

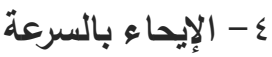

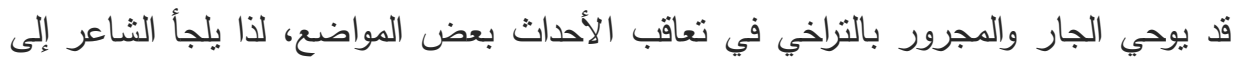

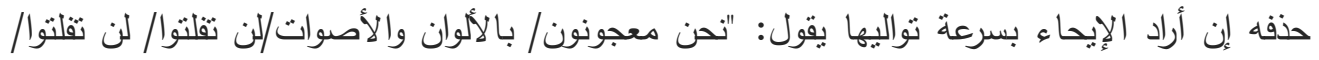

$$
\text { فكلّ بيت فيه بندقية"(ق. منشورات فدائية). }
$$

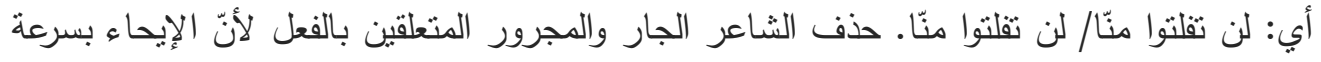

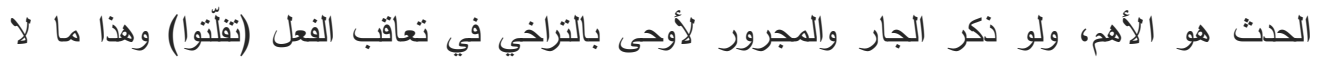

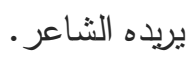


العدد الحادي والأربعون

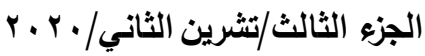

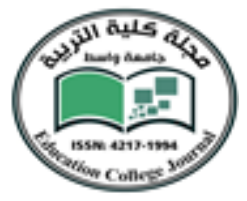

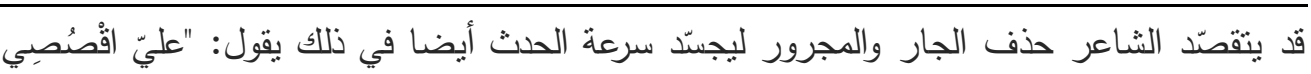
أنباء نفسك وابعثي/ بشكواك، من منلي يشاركك الثكوى"(ق. اكتبي لي).

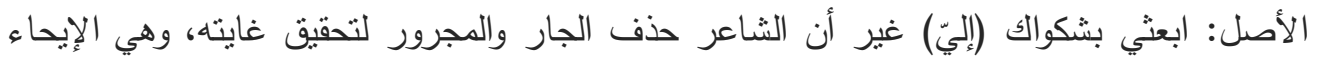

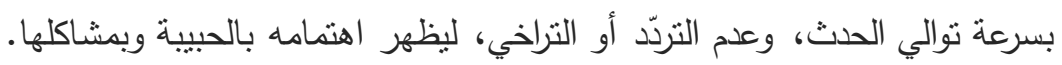

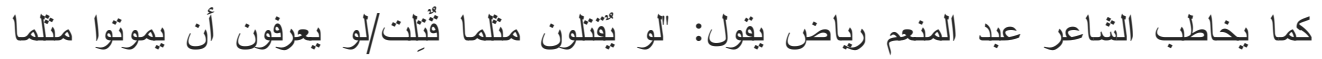

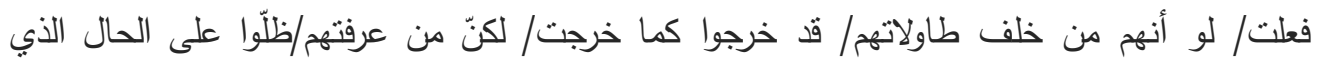

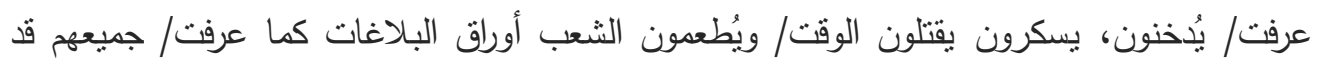

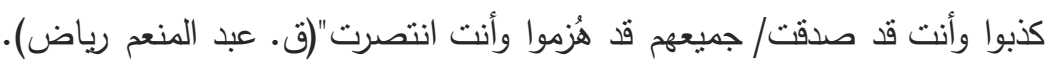

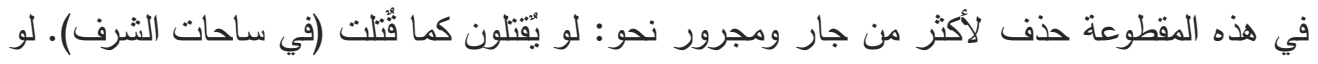

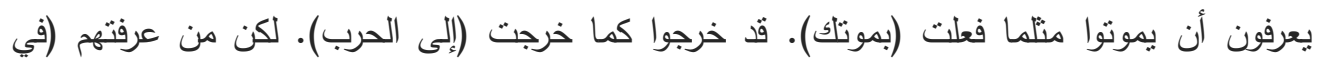

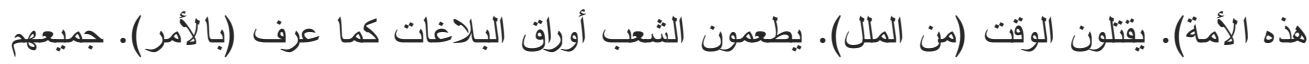
قد كذبوا (علينا) • وأنت قد صدقت (معنا). لو قرأنا المقطع الأول من دون جار ومجرور، وقرأنا المقطع الثاني مع الجار والمجرور المتعلقين

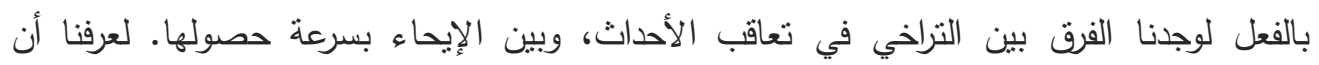

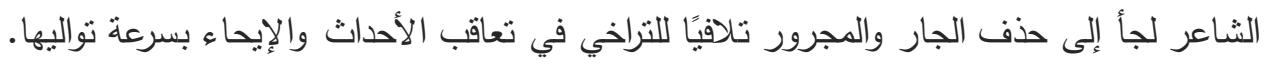
هـ - إقامة الوزن إلى

وهو من أكثر أنواع حذف الجار والمجرور، إذ تحول القافية من دون إيراد الجار والمجرور فيُترك للسامع مهمة تقديره. عمد الثاعر إلى حذف الجار والمجرور المتعقين بالفعل من الجملة، حين كان يتوجه بالخطاب إلى إلى

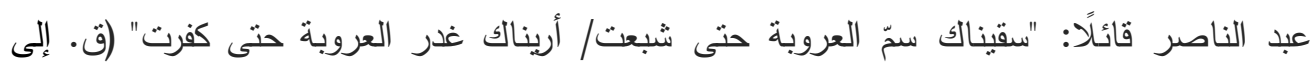
ناصر قتلناك يا آخر الأنبياء). عمد الثاعر إلى حذف الجار والمجرور من جملة شبعت (منها) وكفرت (باللة) لدالالتين ظاهرتين

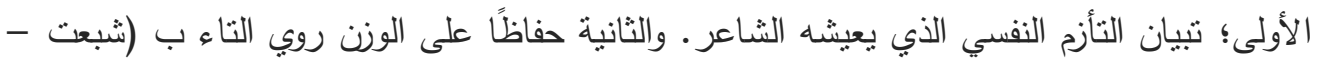
كفرت) ومن مثل ذلك يقول: "إني أراهم، يا أبي، زرق العيون/ سود الضمائر يا أبي، زرق العيون/ قرصانهن

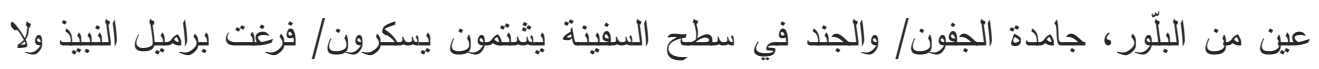
يزال الساقطون/ يتوعدون/"(ق. منشورات فدائية) 
العدد الحادي والأربعون

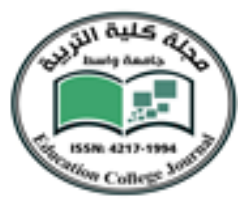

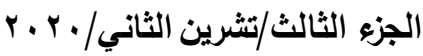

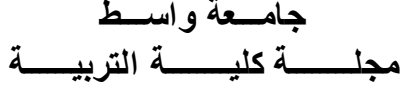

أي: لا يزال الساقطون يتوعدون (بالقتل). حذف الحار والمجرور حفاظًا على الوزن

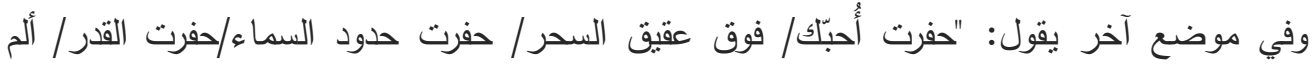
تبصرها؟/ على ورقات الزهر"(ق. أحبّلك). أي حفرت حدود السماء (في) أو حفرت القدر (في). حذف الثاعر الجار والمجرور المتعقين بالفعل

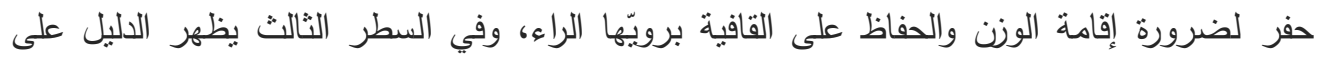
ورقات الزهر ، ولكنّه لا يتعلق بالفعل حفر إنّا بالفعل تبصرها. ولكنّ الدلالة تُفهم من السياق. وفي موضع آخر، عدد الثاعر إلى حذف الجار والمجرور لضرورة إقامة الوزن، يقول:

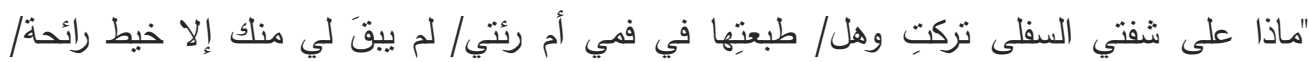

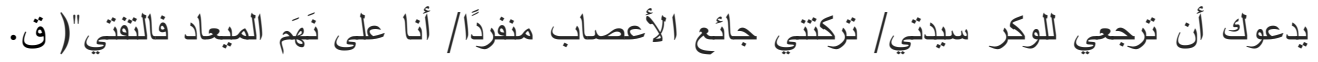

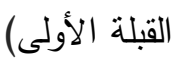
تتالى روي التاء المكسورة أو ما يلائمها (ي) فلجأ الثاعر إلى حذف الجار والمجرور المتعلق بالفعل (التقني) حفاظًا على إقامة الوزن.

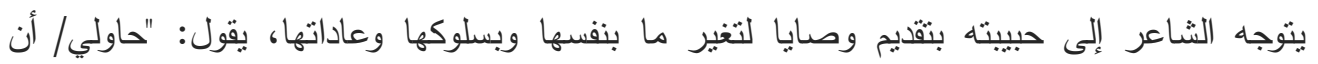

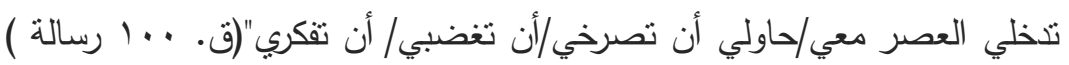

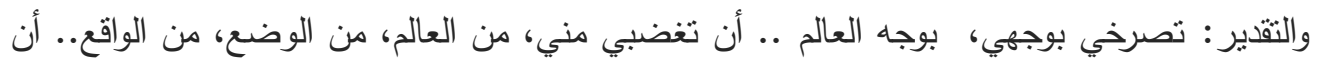
تكفري باله، بالقضية، بالعالم بالوطن.. وغير ذلك. حذف الثاعر الجار والهجرور المتعلقين بالفعل

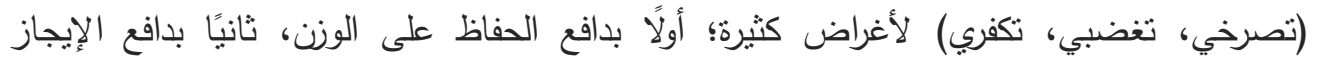

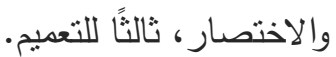

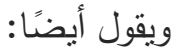

وأن تتام على خصري ذراعاه ونطعم النار أحلى مـا كتبناه

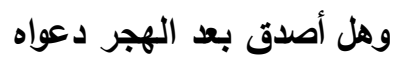

ألم تمت كخيوط الثمس ذكراه

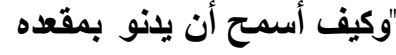
غذًا إذا جاء أعطيه رسائله حبييتي! هل أنا حقًا حبيبته أما انتهت من سنين قصته معي هل أما كسرنا كؤوس العبّ من زمن فكيف نبكي على كأس كسرناه"(ق. ماذا أقول لهل

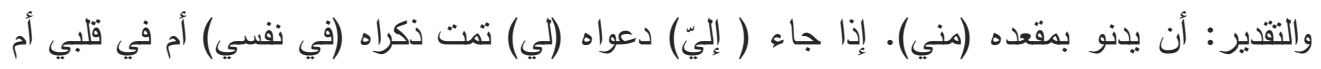
في ذاكرتي. أما كسرنا كؤوس الحب (بأيدينا) فكيف نبكي على كأس كسرناه باء (أيدينا) 
العدد الحادي والأربعون

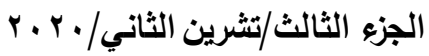

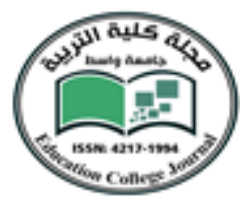

لجأ الثاعر إلى حذف الجار والمجرور من أبيات القصيدة حفاظًّ على الوزن. ولو أضاف الثاعر حرف الجر والاسم الدجرور المتعقين بالفعل لانكسر الوزن، وخرج عن نظامه الخليلي، وهذا مخالف لالشعر العمودي.

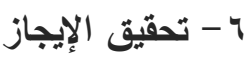

قد يحذف الجار والمجرور إذا ورد ما يدلّ عليهما في الجملة، فيميل الثاعر إلى حذفها

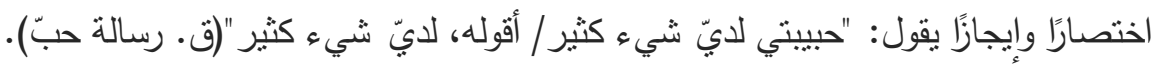
المدذوف (لك) الجار والمجرور المتعلقان بالفعل أقول، وقد عمد الثاعر إلى حذفهما إيجازًا واقتصادًا في الكلام، لدلالة السياق عليه. وفي موضع آخر يقول: وفقدتَ يا وطني البكارة/ لم يكترث أحدُ/ وسجّلت الجريمة ضدّ مجهول/

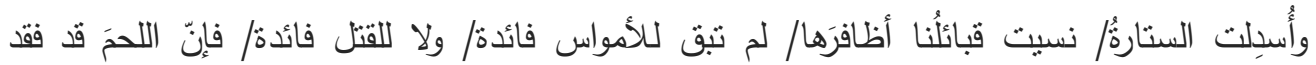

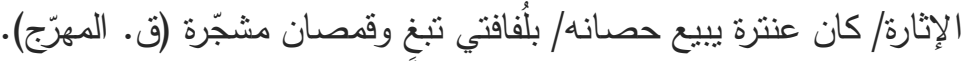

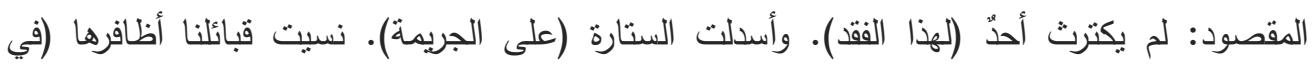
الجريمة) لم تنق للأكواس فائدة (في الوطن). ولا للقتل فائدة (في الوطن). فإن اللحم قد فقد الإثارة

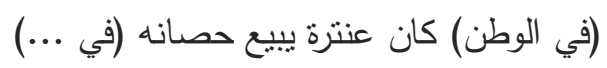

من الواضح أن الحذف للجار والمجرور قد ساهم في الإيجاز، لأنّ الدالالة واضحة من دون ذكرهما

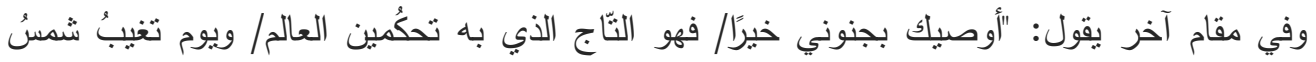

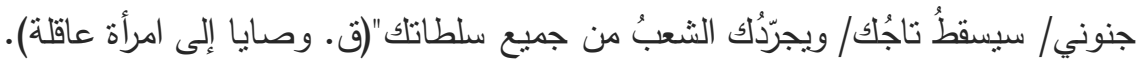

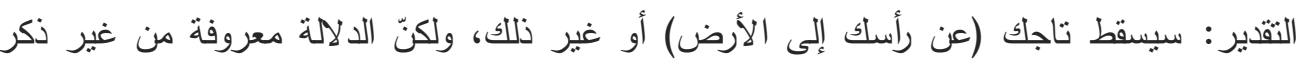

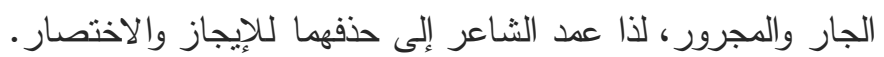

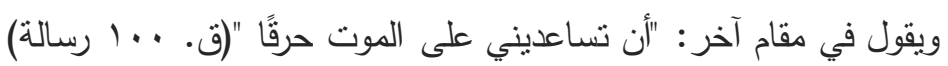
النقدير: حرقا بالنار. وقد حذف النار ولا داعي لذكره فقد اعتد الإيجاز والاختصار لأن السياق

$$
\text { معروف ولا داعي لذكرهما. }
$$

يتبيّن مما تقّم أنّ حذف الجار والمجرور في الديوان كثيرًا، وقد كان له فوائد عديدة سواء بتركيز

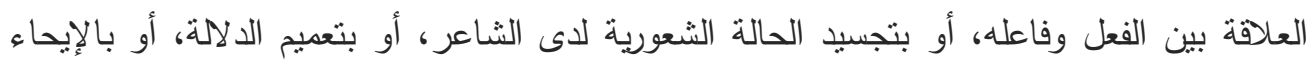
بالسرعة، أو بالإيجاز وإقامة الوزن. 
العدد الحادي والأربعون

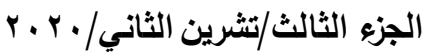

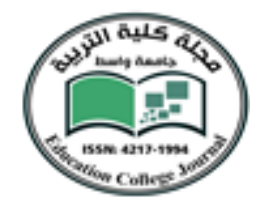

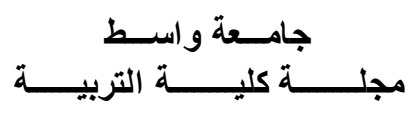

الخاتمة

ابنكر نزار قباني حداثته الخاصة التي تميزه عن الآخرين، باعتماده لغته الخاصة التي تقوح منها

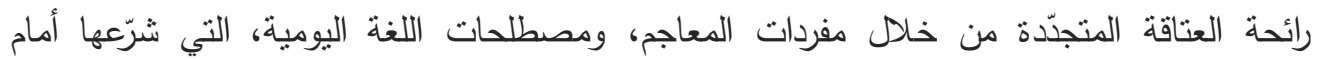
الشعر ، مستثرًا أساليب عديدة من حذف، وتقديم ونتأخير، ، وتعريف وتتكير ـ ولكنّا في دراستتا لظاهرة الحذف في هذا البحث تبين أن الثاعر استخدها في قصائده، واستثرها خير استثمار، محقًَّا

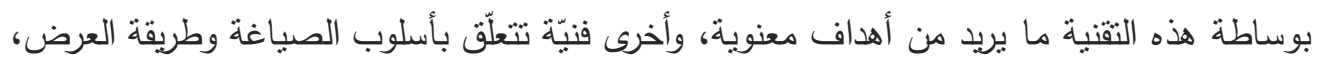

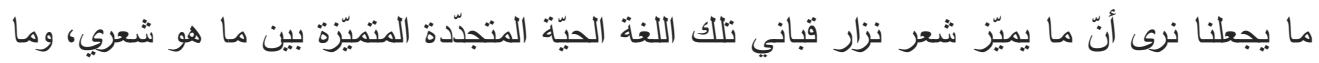

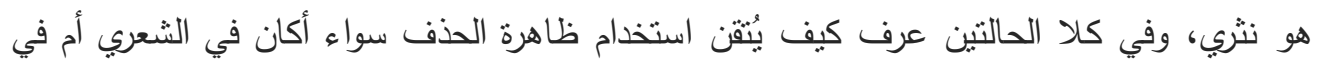

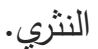
فالسياق التعبيري يظهر قدرة الثاعر على المؤلفة بين الكلمات، وعلى اكتثافه عناصر القوة في بلاغتتا العربية، وعلى استخدامه الألفاظ والمفردات في أسلوب الواقع، وأسلوب المجاز . إن ظاهرة الحذف التي اعتدها الثاعر قد امتلكت ملامح أسلوبية مميّزة، ساهمت في نشكيل صياغته

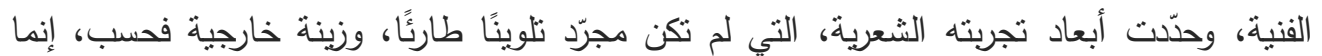

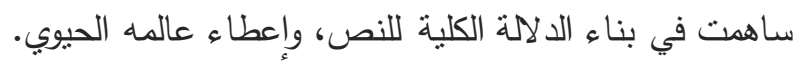

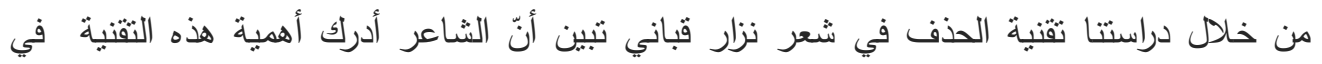

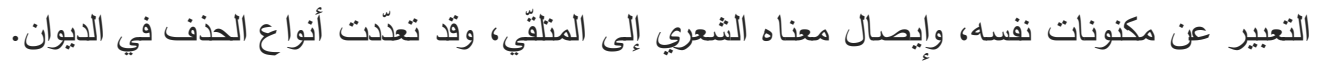
فمن حذف المسند إليه إلى المسند في الجملتين الأسمية والفعلية، ومن حذف الفاعل إلى حذف إلى المفعول، ومن حذف الموصوف إلى حذف الصفة، ومن حذف المضاف إليه إلى حذف المضاف، إلى الئن

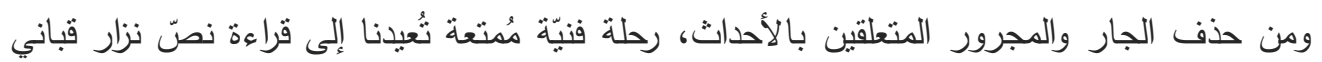

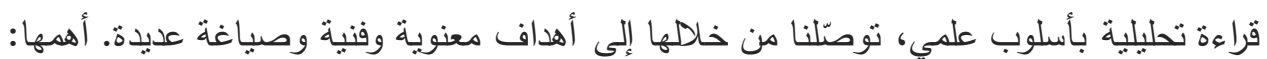

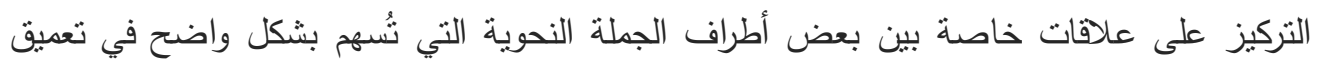

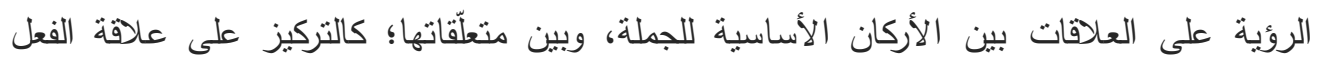

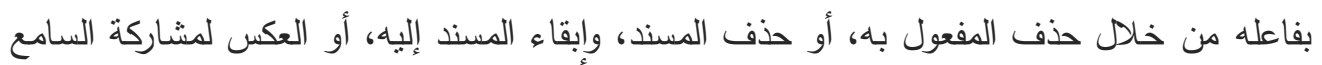
في انتاج النص، أو للإسراع في إيصال المعنى أو لأهداف فنية أخرى.

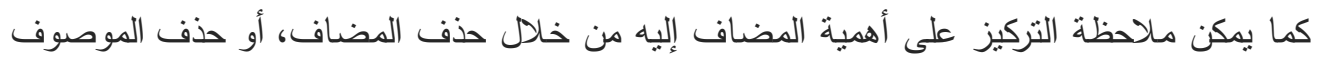

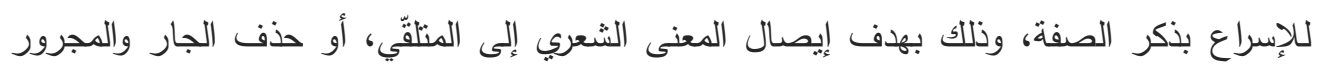

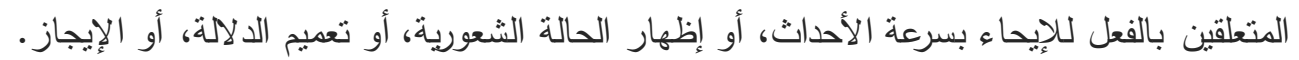


العداد الحادي والأربعون

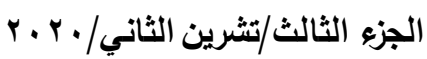

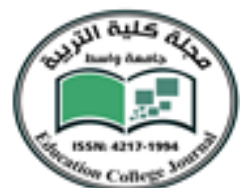

كما حققت تقنية الحذف أهدافًا فنيةً كثثرة؛ أولًا الابتعاد عن النقريرية ، ثانبًا المساهمة في رسم لوحة

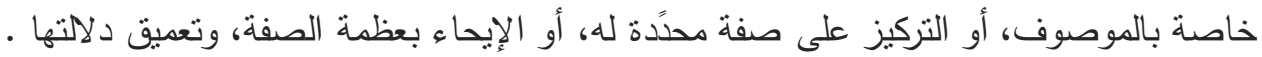

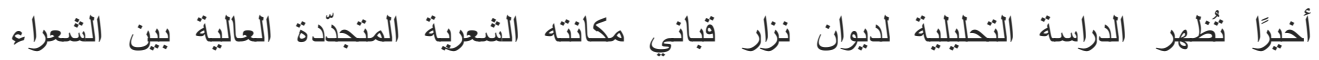

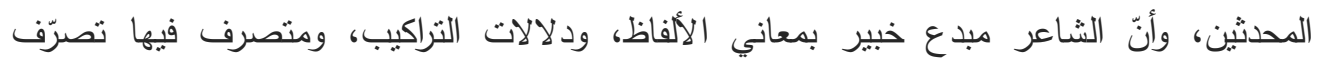

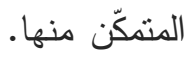
قد تكون نشأته في بيت والده الواسع في دمشق الذي كان كثثر الماء والزهر والثعر، أثر كبير لهذه

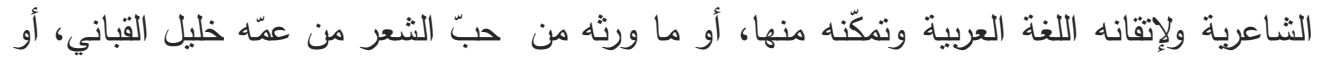

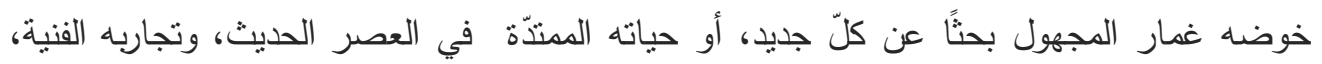
ورحلاته المتعددة، كونه عمل سفيرًا في القاهرة ومدريد ولندن ودبلوماسيا في بيروت والصين، وفجّرت حياته المليئة بالصدمات والظروف السياسية المضطربة التي عاشها في الوطن العربي مكامن الإبداع

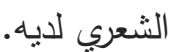
من هنا يمكننا القول أنّ البحث طرق بابًا جديدًا في أعمال نزار قباني، ونكون قد أجبنا عن الأسئلة

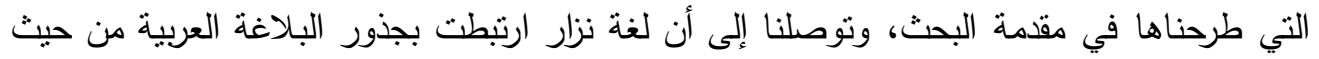

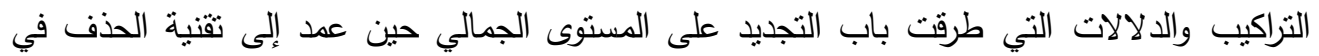

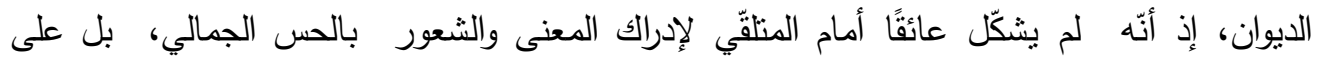

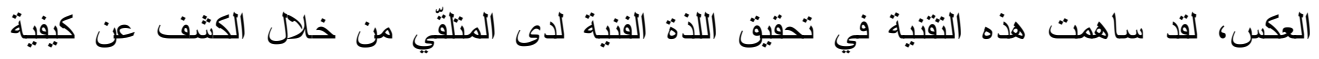

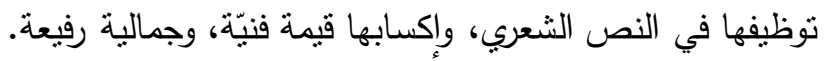


العدد الحادي والأربعون

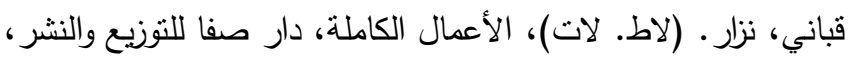

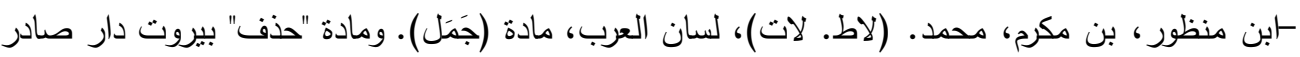

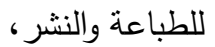

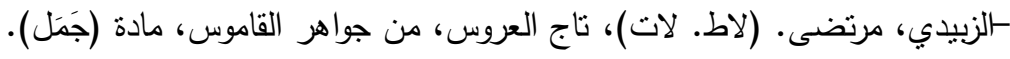

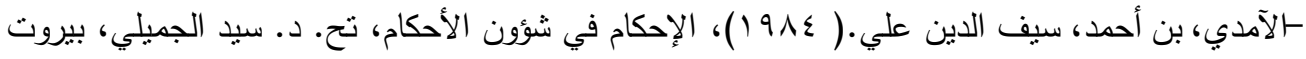

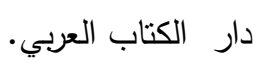
-لاستراباذي، محمد بن الحسن رضي الدين.( (911))، شرح كافية ابن الحاجب، تحقيق د. إيميل بعقوب، بيروت، دار الكتب العلمية.

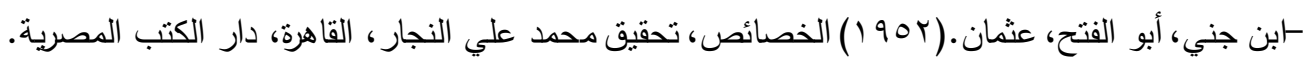

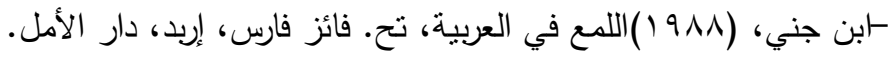
-ابن هثام، بن يوسف، جمال الدين.( ـ99 (1) شرح شنور الذهب، تحقيق عبد الغني الدقر ، مؤسسة الرسالة بيروت. - مبن - ابن هثام. (991) (191) مغني اللبيب عن كتب الأعاريب، تحقيق مازن المبارك، ومحمد علي حمد الله، بيروت،

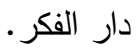
-ابن الأثثر ، الجزري، عز الدين.( لاط. لات)، المتل السائر ، جr، تحقيق محمد ابراهيم البنا وآخرون، دار الثعب -ابن يعيش، بن يعيش، بعيش بن علي. ( • 199) شرح المفصتّ، تحقيق محمد عزّ الدين السعيدي، دار إحياء

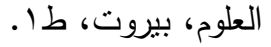

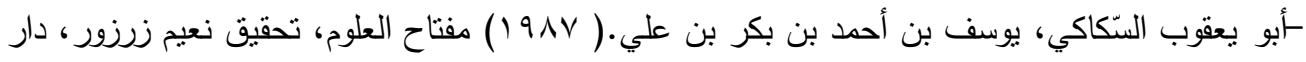

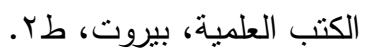
-الجاحظ، بن بحر ، عمرو أبو عثمان. (1979 1) كتاب البيان والتبيين، تحقيق عبد السلام هارون، القاهرة

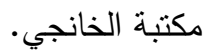
الجرجاني، عبد القاهر .(1999) دلائل الإعجاز في علم المعاني، تحقيق أبو فهر محمود محمد شاكر، ط؟، مطبعة الدني، القاهرة. -لجرجاني، عبد القاهر بن عبد الرحمن بن محمد. (raA1)، أسرار البلاغة، محمد شيد رضا، دار المعرفة

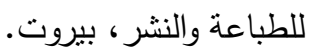

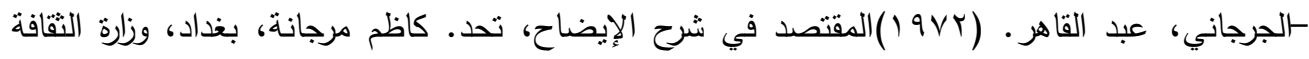


العدد الحادي والأربعون

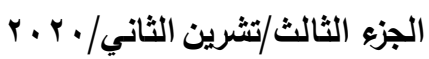

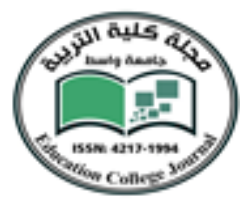

1- الزمخشري، بن عمر بن جار الله، محمود ابو القاسم. (لات) الكثّاف عن حقائق النتزيل، وعيون الأقاويل في وجوه الثأويل، تحقيق مصطفى حسين أحمد، دار الكتاب العربي بيروت.

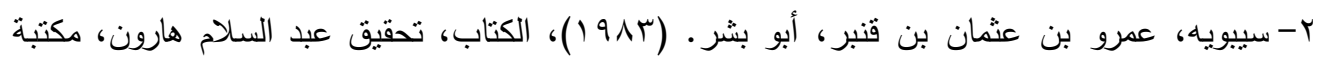

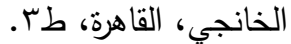

r- الثشاوش، محمد. وآخرون،(7 (91) ) أهم المدارس اللسانية، نونس، وزارة التربية القومية.

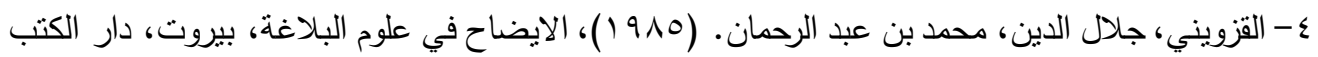
العلمية.

ه- الزركثي، محمد بن عبداله بدر الدين، (90V (1)، البرهان في علوم القرآن، تحقيق محمد أبو الفضل ابراهيم، دار إحياء الكتب العربية، القاهرة طا. 1- الصنّان، محمد بن علي،( لات)، حانشية الصبان على شرح الأثموني على ألفية ابن مالك، بيروت دار

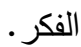
V- العقاد، عباس محمود.(ع (9V))، اللغة الثاعرة، مزايا الفنّ والتعبير في اللغة العربية، القاهرة مطبعة

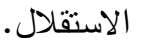

A- المبرّد، بن يزيد أبو العباس محمد.( (99 (1)، المقتضب في النحو، ، تحقيق محمد عبد الخالق عُضَيمة، المجلس الأعلى للثؤون الإنسلامية.

9- الدخزومي، دهدي، (910 (1)، في النحو العربي: قواعد وتطبيق، بيروت دار الرائد.

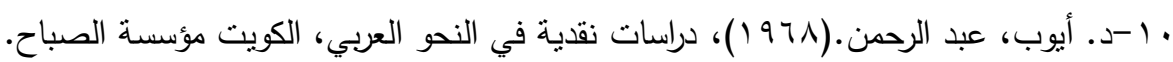

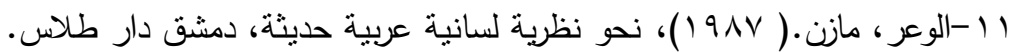

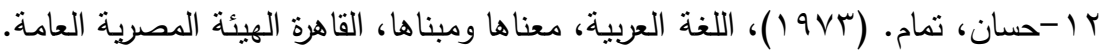

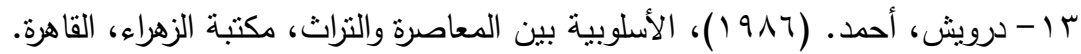

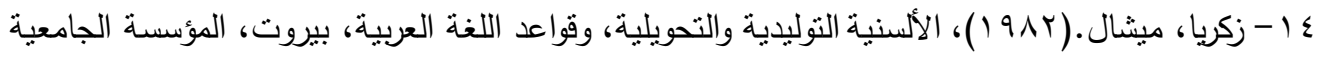

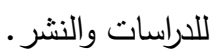
10 - طحان، ريمون. (r/ (1))، الألسنية العربية، بيروت، دار الكتاب اللبناني. 17 - طاهر سليمان حموده. (1991)، ظاهرة الحذف في الدرس اللغوي، الدار الجامعة للطباعة والنثر والتوزيع، الاسكندرية.

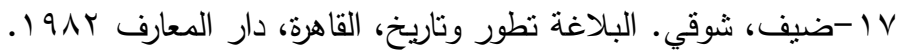

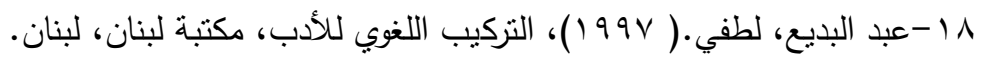

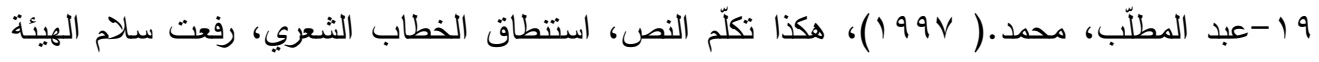
المصرية العامة للكتاب، القاهرة. • ץ-د. عتيق، عبد العزيز .(910 ())، علم المعاني، بيروت دار النهضة العربية. 
العدد الحادي والأربعون

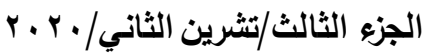

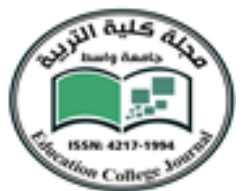

ا (Y-عياد، شكري. (لات)، مدخل إلى دراسة الأسلوب، مكتبة الزهراء، القاهرة،..

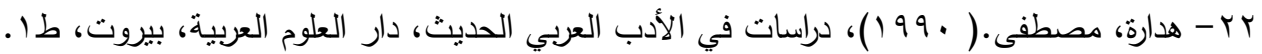

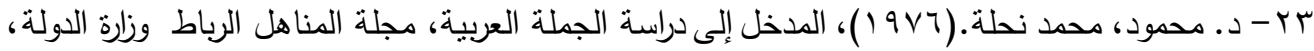

$$
\text { ؟ ك - ثالثاً - المراجع المترجمة }
$$

مارتينيه، أوندري. (910 (1))، مبادئ اللسانيات العامة، ترجمة د. أحمد الحمو، سورية، وزارة التعليم العالي.

צr - ميكاروفيسكي، يان.( ع 91 ()، اللغة المعيارية واللغة الثعرية، ترجمة ألفت الروبي مجلة فصول، القاهرة،

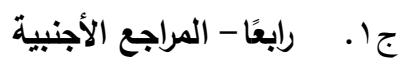

27- bloomfield,L.(1950), Language, George Allen \& Unwin, London

28- rChalker,s. \& weiner, E.(1994),the oxford Dictionary Grammar oxford University press.

29- Huddleston, Rodney (1986) introduction to English Transformational Syntax, Longman Group, Ltd. U. k. 